\title{
Um corpo feito de olhares (Amazônia) $^{1}$
}

DOI

http://dx.doi.org/10.11606/ 2179-0892.ra.2019.165236

Tradução

Daniel Calazans Pierri

Revisão técnica

Renato Sztutman e

Eduardo Viveiros de Castro

Revisão

Léa Tosold
A seguinte história foi relatada por Peter Cow, um etnólogo especialista nos Piro da Amazônia peruana. Em uma missão em Santa Clara, uma professora preocupada em inculcar nos Piro noções de higiene se esforçava em convencer uma mulher a utilizar água fervida para preparar o alimento de seu filho. A mulher exclamou: "Se bebemos água fervida, pegamos diarreia". A professora repreendeu a mãe: "Todos sabem que é o consumo de água não fervida que provoca diarreia infantil, e não o inverso". Impassível, a mulher piro retorquiu: "Talvez isso seja verdade para as pessoas de Lima, mas, para as pessoas daqui, água fervida dá diarreia. Nossos corpos são diferentes dos seus". Diferentes em que e por quê?

Na Melanésia, a formação do corpo humano opera por subtração e especialização: andrógino ou indiferenciado na origem, o corpo se torna humano adquirindo um gênero à medida que ele se desfaz dos elementos que remetem ao outro sexo. Nos modelos de representação do corpo humano na Europa e na África, este é pensado em função de um tipo ideal, do qual recebe de uma só vez sua forma e seu destino. Existe, entretanto, outra maneira de variar esse princípio de incompletude que faz com que um corpo não se baste nunca a si mesmo. Trata-se de imaginar que sua forma é determinada pelo olhar dirigido a ele, em função da relação que se estabelece com ele. Essa maneira de conceber o corpo é comum entre os povos indígenas das terras baixas da América do Sul. Dentre todas as configurações examinadas até aqui, esta é aquela cujas implicações são mais desconcertantes para um espírito ocidental. Neste caso, o corpo humano não mais ocupa um lugar único e estável no esquema do cosmos, já que sua forma é inteiramente relativa à perspectiva de um testemunho - humano ou não humano -, fornecido pelo olhar do outro, em vez de ela ser um atributo essencial de uma dada classe de seres.
1 [Nota da Tradução] O presente texto foi originalmente publicado em francês como parte do catálogo da exposição Qu'est-ce que un corps? [O que é um corpo?], realizada pelo Musée du Quai Branly, em Paris, entre março de 2006 e setembro de 2007. Tratou-se da primeira exposição antropológica do então recém inaugurado museu, e teve como mote a comparação sobre a maneira pela qual 'corpo' e 'pessoa' são representados em quatro regiões do mundo, a saber, o oeste da África, a Europa ocidental, a Nova Guiné e a Amazônia. O texto "Corpo Feito de Olhares" foi escrito em coautoria por Eduardo Viveiros de Castro e Anne Christine Taylor, analisando a sessão amazônica da exposição, da qual ambos foram organizadores. Taylor, à época, também era diretora de ensino e pesquisa no museu." 


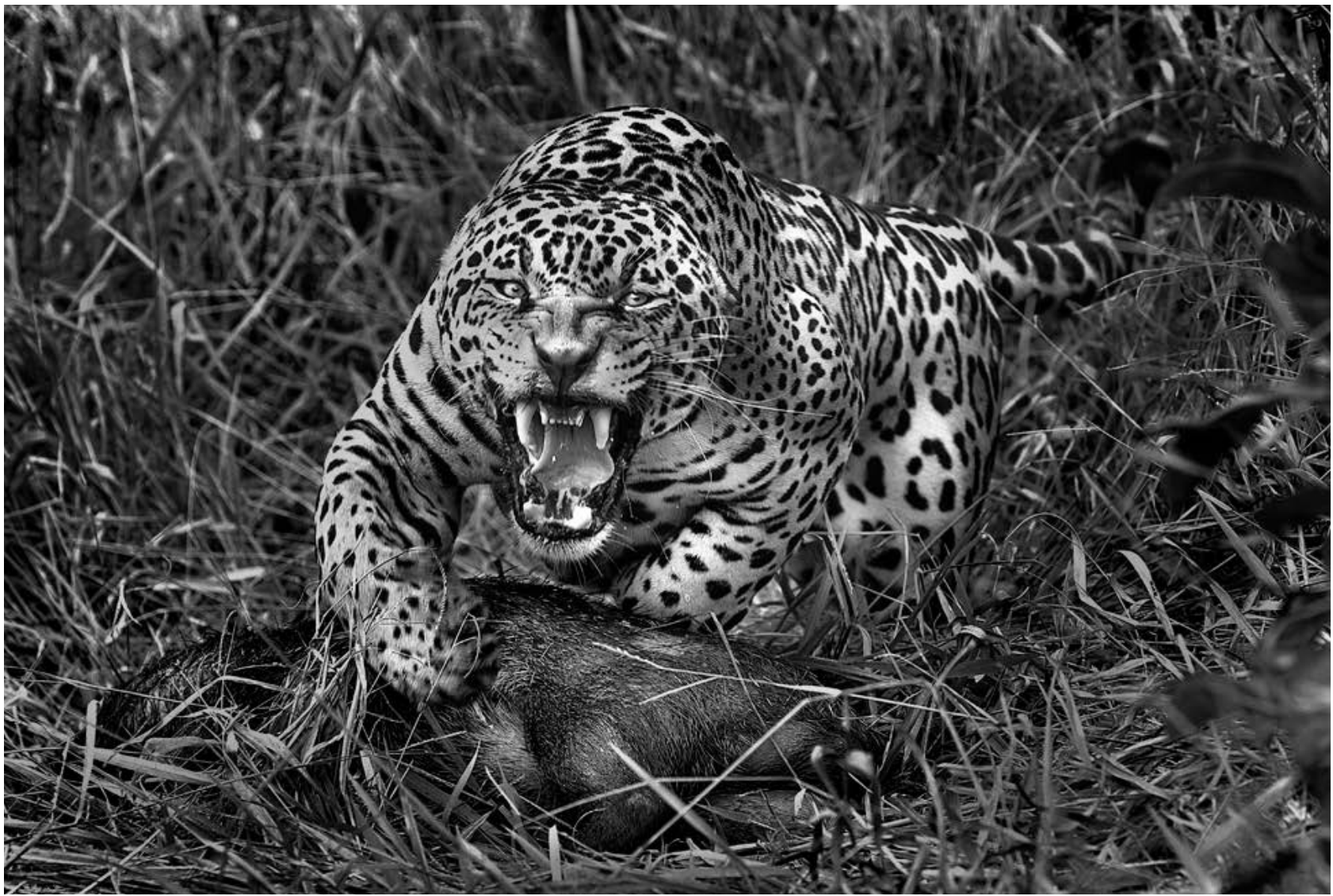

As ontologias amazônicas que concebem esse tipo de corpo tendem todas a atribuir uma posição de sujeito - calcada naquela própria aos humanos - a um grande número de seres não humanos, sejam eles espíritos, animais, plantas ou a posição de "predador". Foto de Araquém Alcântara. artefatos. Essa disposição, comum ademais a numerosas culturas não ocidentais, é designada na antropologia pelo termo "animismo". Ela se baseia ainda na ideia de que a aparência manifestada por outro ser é uma questão de perspectiva: a identidade do corpo percebido depende da natureza do corpo da "pessoa" que está na origem do olhar. O corpo não pode, portanto, ser considerado fora de sua relação necessária com um observador em função de sujeito; mas, reci(www.nickgarbutt.com) procamente, nenhum sujeito pode ser concebido sem uma inscrição corporal determinada. Essa forma de relativizar a identidade dos existentes é chamada "perspectivismo" pelos etnólogos especialistas na área amazônica.

Essas ontologias qualificam a relação que faz a identidade do corpo em função de um esquema geral, a "predação", fundado sobre uma

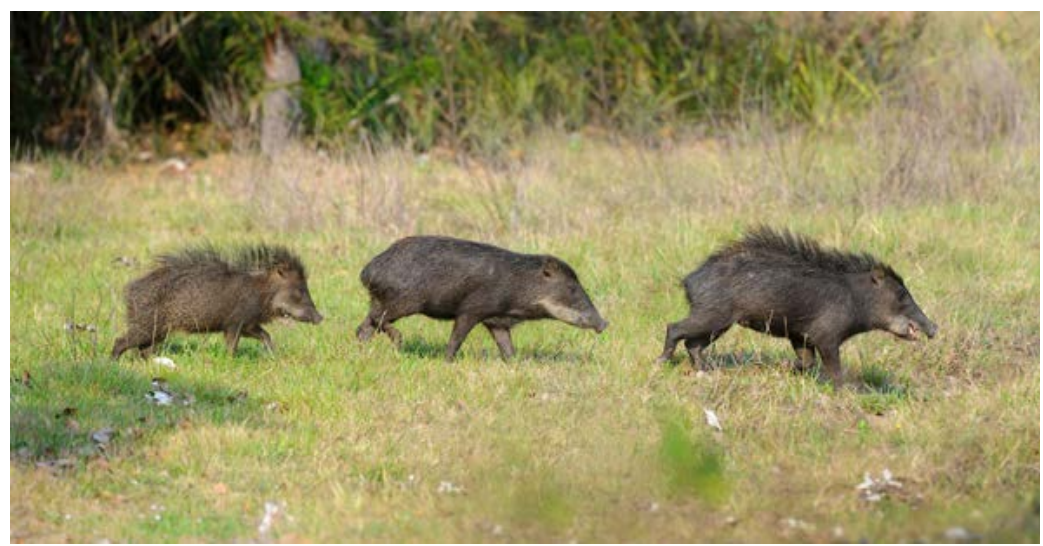


amplificação metafísica da noção de cadeia alimentar: para crescer e existir, todo ser deve se alimentar de outros seres. A pulsão predadora é, portanto, inerente a todas as entidades vivas, sejam humanos, animais, plantas ou espíritos. Seguindo a grade de leitura das relações entre

os seres que decorre dessa intuição, só é possível ocupar, em face de outra criatura, uma destas três posições: a de predador, a de presa, e a de congênere. Assim, de acordo com a posição na qual se encontra um outro do ponto de vista de um sujeito qualquer, a natureza do corpo por meio do qual esse outro aparece varia. Se sou suscetível de ser comido por outro, este se manifesta com um corpo de jaguar, de gavião real, ou de espírito canibal. Se, ao contrário, ele é uma presa para mim, eu o vejo como um pecari, ou um tatu, e tenho sobre ele o ponto de vista de um jaguar. Se o outro é semelhante a mim - se ele come como eu e comigo-, ele oferece a meus sentidos um corpo humano, e é representado como tal (fig. 1 a 3$)^{2}$.

A linguagem visual utilizada para falar dos corpos alheios descreve relações entre seres animados. A morfologia não dá ao corpo identidade específica. Se eles falam em "ver" o corpo do outro sob tal ou qual forma - e eventualmente de fato assim o

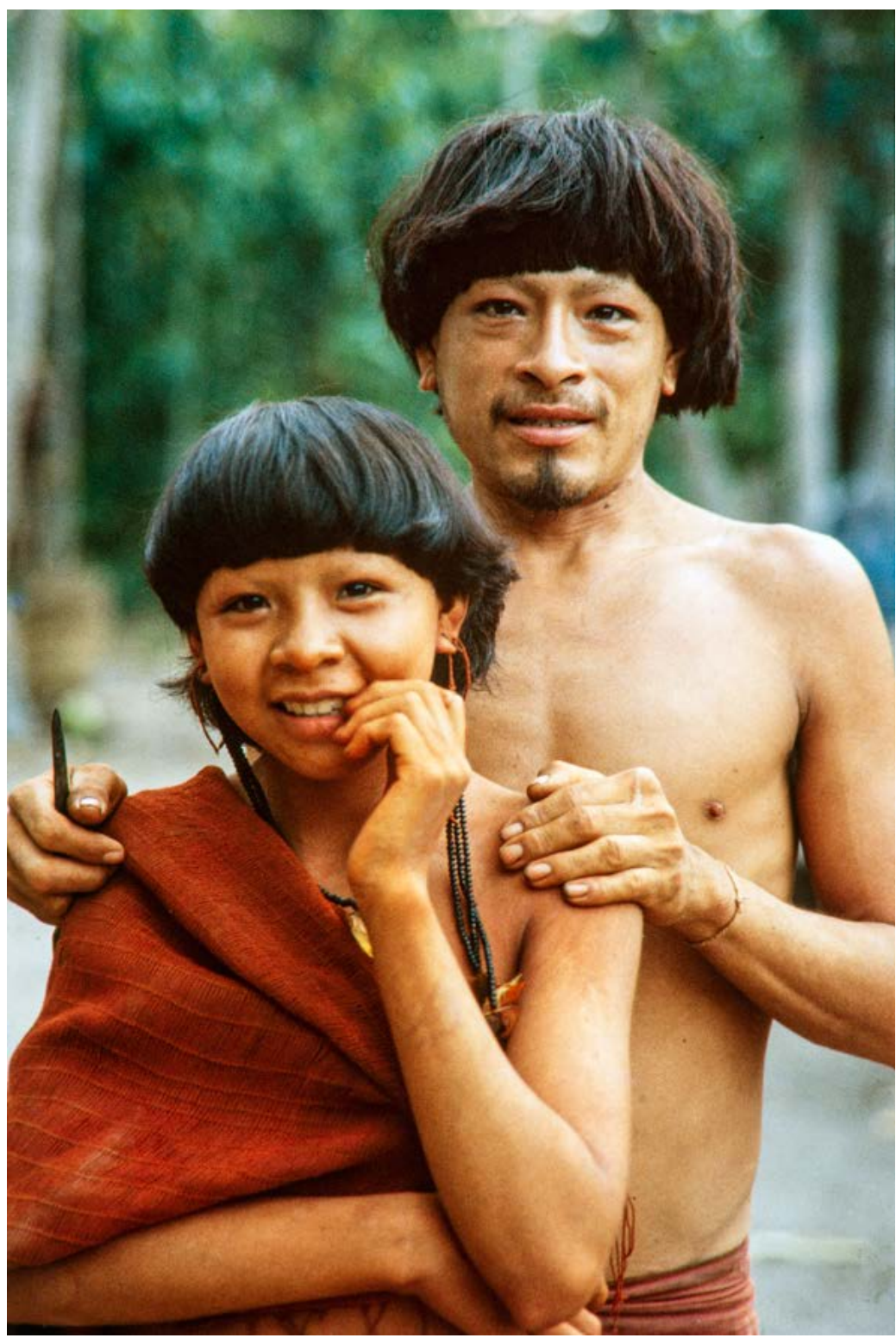
vejam -, os povos indígenas da Amazônia fazem uso de uma imagem concreta para se referir a uma noção na realidade muito abstrata: a percepção, ao mesmo tempo sintética e difusa, de intenções que cremos descobrir no corpo do outro de acordo com as atitudes - amigáveis, sedutoras, ameaçadoras - que ele adota no curso de uma interação. As disposições afetivas inscritas nos signos corporais são figuradas pelos comportamentos ou 2 [Nota da Tradução] As figuras 1 e 2, que ilustram as posições de 'presa' e 'predador', foram substituídas em relação às usadas no texto original, pois estas não tiveram autorização para publicação. pelas atitudes típicas de diversos animais. Por metonímia, estes acabam por servir de ícone para as formas de relação. Desse modo, dizer que "vemos um jaguar" quando nos encontramos em situação de eventual vítima é uma maneira concisa 


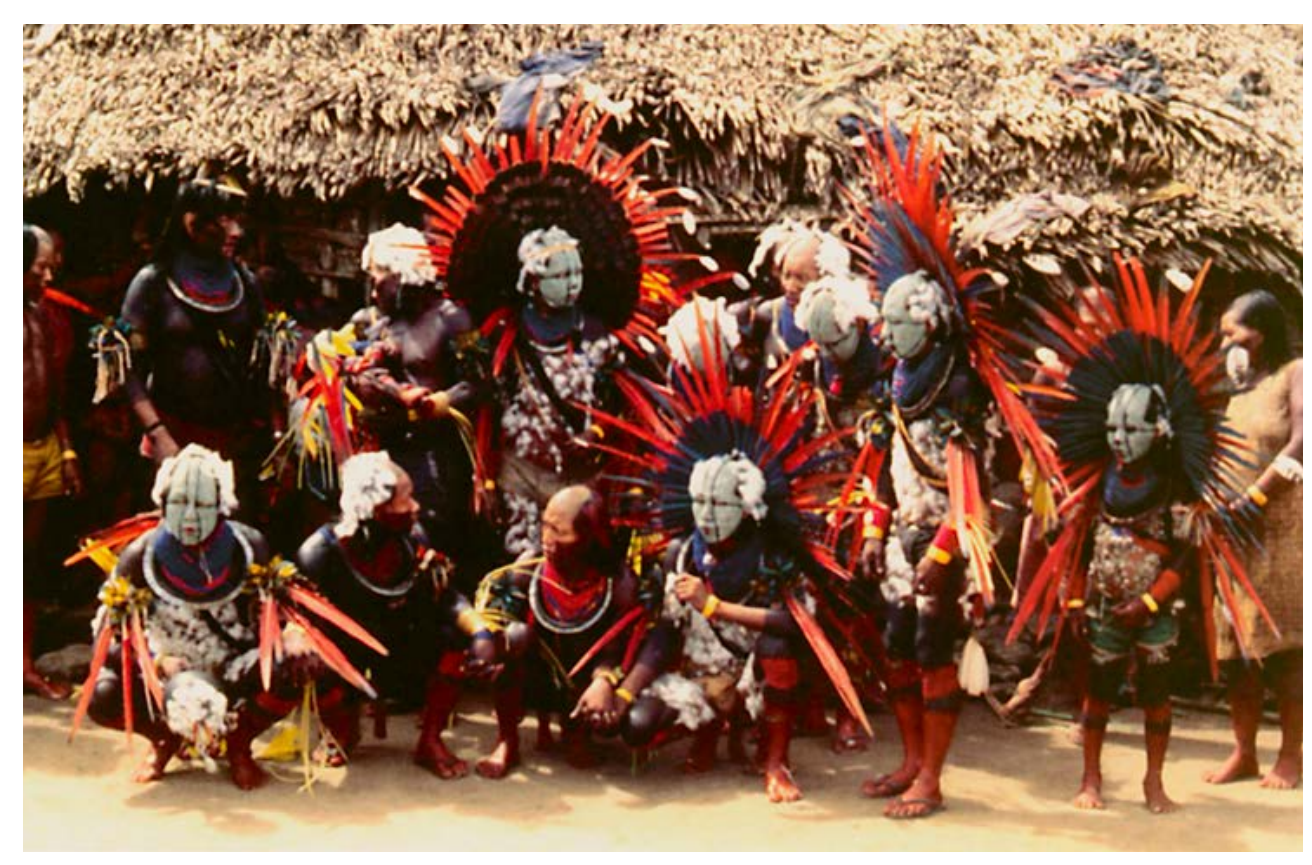

\section{Figura 4}

Grupo de índios, população xikrin (1985). Foto de Lux Vidal (Acervo LISA). "O corpo é a produção mais valorizada na Amazônia, os adornos e as pinturas corporais manifestam seu caráter propriamente humano".

de designar a sensação experimentada por um corpo na presença de outro corpo motivado por intenções agressivas contra si.

A atualização das maneiras amazônicas de mobilizar os corpos deparase, entretanto, com uma dificuldade particular. Essas culturas se negam a dar uma forma material, destacada do corpo, às relações que se estabelecem em torno dele: diferentemente daquelas da Nova Guiné, da África Ocidental ou da Europa, as sociedades da bacia amazônica produzem poucas imagens tangíveis do corpo sob a forma de gravuras, esculturas ou pinturas. Elas não fabricam representações do corpo; elas fabricam antes de tudo corpos. Os utensílios são pensados, descritos e frequentemente decorados como corpos. A "obra de arte" que importa na Amazônia é o corpo humano. Todo o imaginário formal dessas culturas e as técnicas que ele alimenta são orientados para esse corpo, cuja ornamentação espetacular contrasta com a sobriedade dos objetos com os quais convivem os habitantes da Amazônia (fig. 4). Adornos, pinturas corporais e máscaras não têm sentido senão quando vestidos por um corpo vivo. Longe de serem simples decorações, algum tipo de fantasia, esses artefatos são literalmente prolongamentos ou elementos do corpo. Eles devem ser animados, no sentido próprio do termo, ou não são nada.

Nessas condições, mais que mostrar as peças como obras significativas em si mesmas, optamos por evocar as práticas e as formas de representação a que elas remetem. Para manter fidelidade ao espírito da cultura visual dos povos da Amazônia - com o risco de afastamento da letra da etnografia -, não hesitamos em associar desordenadamente objetos provenientes de sociedades distintas e que estão associados a interpretações simbólicas diferentes; recorremos também várias vezes a imagens fotográficas de pessoas. 


\section{CORPO DE CONGÊNERE, CORPO DE HUMANO}

O que nesse universo amazônico justifica que um corpo possa ser apreendido ou "visto" como humano? Um corpo de humano é a materialização de uma relação de filiação ou de aparentamento, ou seja, de uma relação que não é nem de predador nem de presa. $\mathrm{O}$ "humano" é a forma que toma um corpo de um parente ou de um congênere: de maneira mais geral, é a forma de toda criatura percebida como semelhante, quer dizer, como sujeito. Se, por um lado, os jaguares veem os ("verdadeiros") humanos como queixadas (portanto como presas), por outro lado eles se percebem como pessoas humanas, e este é o caso para todas as espécies contextualmente dotadas de disposições relacionais. A humanidade é dessa forma um modo de percepção acessível a todos os tipos de seres, e de maneira nenhuma uma espécie natural.

A posição que define o humano não se situa no mesmo nível que aquela de predador e presa. A posição de predador ou de presa, fundada sobre uma presunção de diferença, é sempre primeira. Longe de a predação ser um acidente da relação entre semelhantes, é, ao contrário, a relação de identidade definidora do humano que se mostra um caso particular da relação de predação. $A$ humanidade deriva da suspensão ou da negação da predação, ela não a precede. A inimizade-designemos por esse nome a relação de consumo agressivo - é dada, ao passo que a humanidade é produzida: ela emerge de uma troca de intencionalidades e se revela ou cristaliza progressivamente. A linguagem dos Wari' do Brasil oferece uma bela ilustração dessa estrutura: "gostar ou pensar em alguém com saudade" exprime-se por uma locução que, literalmente, significa "deixar de sentir raiva", em suma, "des-odiar".

\section{O que significa "ser humano"?}

Está claro que as duas palavras acima empregadas, "pessoa" e "humanidade", designam noções amazônicas muito diferentes daquelas de nossa própria tradição cultural. Na conceptualização dessas noções, os ameríndios mostram-se em certos aspectos mais restritivos que nós. Os termos vernaculares que designam a pessoa ou o ser humano são antes de tudo etnônimos: eles denotam em primeiro lugar os membros do grupo étnico ou tribal ao qual pertence o enunciador, ou ainda apenas aqueles de seu grupo local, ou até mesmo exclusivamente os membros de sua parentela. As únicas verdadeiras pessoas são portanto aquelas que o locutor reconhece como "não outras", seus semelhantes ou seus parentes. Não obstante, os termos indígenas têm também, por outro lado, uma acepção mais abrangente que os nossos, pois incluem muitos outros seres além daqueles que nós classifi- 
camos como humanos. Os povos das terras baixas da América do Sul tendem a antropomorfizar uma série de entidades não humanas, a imaginá-las e eventualmente representá-las sob uma forma humana. Assim, é comum ouvir os indígenas afirmarem que tal planta selvagem ou doméstica é, ou foi outrora, um humano particular, que os queixadas ou os macacos vivem em suas aldeias "como nós", ou que tal cesto, tal motivo de pintura corporal, tem uma boca, sentidos e uma intencionalidade análogos aos dos humanos ${ }^{3}$.

O mesmo termo pode designar tanto apenas os membros do círculo familiar do enunciador, quanto o conjunto de entidades suscetíveis de dizerem "eu", ou seja, a classe de enunciadores em seu sentido mais amplo. Neste último caso, o domínio indígena do humano excede largamente o domínio ocidental; no primeiro caso, inclui apenas uma ínfima parte dele. E a qualidade de pessoa reconhecida em um animal ou planta pelo informante indígena pode ser negada no dia seguinte em outro contexto, sem que essa labilidade seja considerada desconcertante. O pertencimento ao gênero humano é elástico na sua extensão e flutuante no tempo.

Mas, então, o que significa "ser humano" na Amazônia? Numa perspectiva ocidental, é um tipo específico de interioridade que define o humano - uma alma, um espírito racional, uma faculdade linguística ou uma disposição moral - e não a natureza de seu corpo (muito pelo contrário, essa natureza o lança em direção à animalidade). Para os povos indígenas, não é a dimensão subjetiva que forma o núcleo da "humanidade" tão generosamente distribuída entre os existentes do mundo. Dizer de uma entidade que ela é uma pessoa significa, antes de tudo, atribuir a ela uma qualidade de membro de uma comunidade: o "humano" só pode ser algo coletivo, e a "pessoa" representa um pedaço de sociedade antes de ser um indivíduo com destino e caráter individuais. Mas aqui também é preciso compreender que, para as populações amazônicas, a ideia de sociedade tem um sentido bem diferente do nosso. Para nós, a sociedade é um agrupamento de indivíduos que, em consequência de um "contrato", resolvem viver juntos. A sociedade, ao menos na forma como gostamos de representá-la, resulta de vontades autônomas e separadas; seu modelo fundamental é a comunidade livremente escolhida pelos seus membros. Nada disso é o caso para os povos da Amazônia: o modelo de coletivo ao qual se deve estar filiado para ser humano é o da espécie natural, o princípio é o de "quem se parece, se junta"4. Toda espécie - todo coletivo formado por existentes unidos pela aparência e pelo comportamento - forma uma sociedade. Reciprocamente, toda sociedade - a começar por aquela a que pertence o enunciador indígena - constitui uma espécie.

$O$ reconhecimento de uma identidade dos seus membros e entre seus membros, que se atualiza numa sociabilidade intrínseca às interações entre seres semeIhantes, mantém unido esse tipo de coletivo, cujo modelo são os distintos conjuntos presentes na natureza. A simpatia espontânea diante de um outro semelhante
3 [Nota da Tradução] O texto original faz menção nesse ponto à figura "Lança cerimonial, população munduruku", presente no acervo do Staatliches Museum für Völkerkunde, de Viena. Não foi fornecida autorização para publicação dessa imagem, de modo que remetemos o leitor ao texto original para acesso a ela. A legenda da imagem no texto original dizia: "O rosto esculpido sobre esta lança cerimonial figura a qualidade de pessoa revestida por ela em certos contextos rituais".

4 [Nota da Tradução] No original "qui se ressemble s'assemble", expressão que pode ser considerada equivalente a "dize-me com quem andas e te direi quem és”. 
a si mesmo se exprime em modos de ação e em comportamentos que pressupõem atitudes definidoras a um só tempo da subjetividade e do corpo de um sujeito. Assim, antes de ser um princípio que justifica a posição de sujeito, a corporeidade humana e a subjetividade ou interioridade derivam da qualidade de membro de um grupo. Elas são o efeito deste atributo e não sua causa. Com efeito, ser uma pessoa, e portanto membro de uma sociedade, é possuir por isso as disposições para se engajar em diferentes formas de interação com outrem, e é também ter o corpo que se presta a isso. A intencionalidade e a forma por meio das quais são atribuídas as entidades-pessoas consistem precisamente no conjunto dessas capacidades relacionais. Elas representam o kit requerido para pertencer a um coletivo, mas não são, enquanto tal, o critério principal de um estatuto de pessoa ou de humano.

Do que é feito o conjunto de disposições que constitui a subjetividade? Antes de mais nada, da possessão da "linguagem", no sentido amplo, ou seja, de uma ferramenta de comunicação com seus semelhantes e de ação sobre eles;

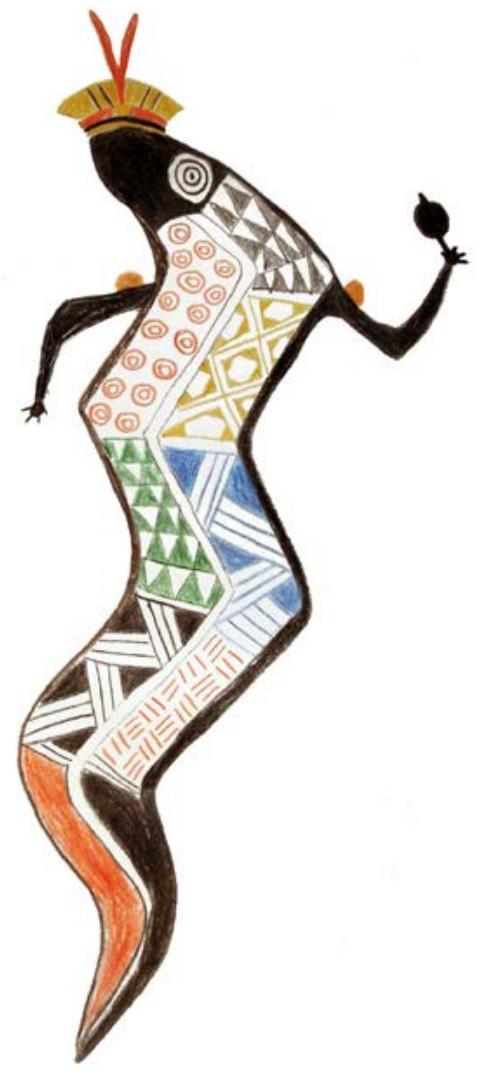
mas também de outras "faculdades", especialmente a arte de ornamentar e pintar o próprio corpo e o de seus próximos. Ocupar uma posição de sujeito supõe possuir, ao menos virtualmente, as formas de conhecimento do mundo reconhecidas em uma dada cultura: não apenas os saberes técnicos e sociais, mas também os saberes mais esotéricos, que dizem respeito aos aspectos do mundo que não são imediatamente visíveis a todos - especialmente os saberes depositados nos mitos, como, por exemplo, o conhecimento sobre a aparência precisa de um animal quando ele assume a posição de sujeito. Essas diversas aptidões inerentes à "personitude"5 atribuída pelos índios a outros humanos ou não humanos se acompanham de um correlato corporal: ser um sujeito (portanto um sujeito social, portador de cultura) é dispor de um corpo análogo ao dos humanos quanto a suas modalidades sensoriais, sua anatomia, sua organização interna e, sob certas circunstâncias, sua aparência. A aptidão de interagir verbalmente, a consciência de ter (e de ver em seus semelhantes) um corpo de tipo humano, dotado de adornos, pinturas e ornamentos, o saber agir sobre outrem e sobre a matéria, o saber "metafísico" - tudo isso constitui uma interioridade desse "membro de um coletivo" que é a "pessoa", tal como ela é concebida pelos povos amazônicos (fig. 5).

Um sujeito amazônico ou um humano, em resumo, é um ser que tem as propriedades corporais, as disposições e as aptidões necessárias para manter relações com seus congêneres. A subjetividade não tem grande coisa a ver com esse espaço

5 [Nota da Tradução] "Personitude" é a tradução adotada aqui e no original francês para o termo inglês "personhood", que não possui equivalente dicionarizado exato em português. Doravante escreveremos personitude sem aspas. 
privado, opaco ao outro, anterior a toda forma cultural e social que associamos à mente ou espírito. Sua interioridade é constituída precisamente por esse conjunto de coisas que nós agrupamos sob o termo cultura - a essência, aos nossos olhos, de um domínio público, partilhado por todos. Enquanto para nós a cultura se associa ao domínio da convenção, da regra e do artifício - em uma palavra, da variabilidade -, do ponto de vista indígena ela é um atributo natural da sociabilidade intra-específica e de maneira nenhuma uma questão de escolha coletiva, de inconstância histórica ou de determinismos oriundos do meio natural. Tudo o que a compõe é inerente à sociabilidade partilhada pelos indivíduos - sejam eles animais desta ou daquela espécie, espíritos, ou simples humanos - que se reconhecem e são reconhecidos por outros como semelhantes.

\section{Perspectivismo: o corpo como ponto de vista}

Entretanto, o princípio do animismo - tal como nós o caracterizamos para tratar das sociedades das terras baixas da América do Sul - não é capaz, por si só, de dar conta da inflexão própria das cosmologias amazônicas, em particular das suas representações sobre o corpo. Essas concepções manifestam um traço que a tendência a atribuir personitude a não humanos não é o bastante para explicar: trata-se do fato de que, se todos os sujeitos atual ou virtualmente reconhecidos no mundo tomam a forma da pessoa humana, esses sujeitos idênticos não veem necessariamente da mesma forma as coisas que compõem este mundo. Assim, os queixadas percebem-se a si mesmos e se veem entre si com corpos de humanos, da mesma maneira que os humanos propriamente ditos. Isso decorre do julgamento de identidade que eles aplicam sobre si mesmos, e uns sobre os outros, e também da dinâmica de sociabilidade suscitada pelo reconhecimento de estar entre semelhantes. Esses mesmos sujeitos queixadas, porém, percebem os (verdadeiros ${ }^{6}$ ) humanos com um corpo de jaguar e não em forma humana. $A$ primeira parte da proposição - ver-se com um corpo humano, mesmo se somos não humanos - se inscreve na lógica do princípio do animismo. A segunda parte introduz nessa configuração um elemento de complexidade que estamos longe de encontrar em todos os universos animistas. Se conferir uma posição de sujeito a não humanos implica na atribuição de um conjunto de disposições e de capacidades de percepção idênticas àquelas das quais gozam os humanos, seria lógico supor que o que é captado por essas faculdades comuns de percepção é igualmente idêntico: todos os sujeitos devem compartilhar o mesmo ponto de vista. Mas, justamente, não é isso que se passa: a homogeneidade do princípio das pessoas-sujeitos combina-se com uma heterogeneidade dos mundos percebidos. Dito de outra forma, os sujeitos não humanos podem considerar segundo perspectivas diferentes um mundo composto do mesmo estoque de elementos,
5 Verdadeiros para nós, bem entendido [Nota acrescentada por Viveiros de Castro a esta tradução]. 
que mudam de natureza em função da identidade do testemunho que está na origem da percepção. Para um sujeito-jaguar, por exemplo, o sangue das presas constitui (é visto como) cerveja de mandioca ou de milho, tal como essas são percebidas pelos humanos. Para as pessoas-colibri, por sua vez, é o néctar das flores que funcionará como cerveja e lhes aparecerá como tal. O elemento estável dessa configuração é a cerveja de mandioca. Em numerosas culturas amazônicas ela é de fato um componente essencial de sociabilidade. O conjunto de relações afetivas, de gestos, de modos de fazer, de modos de viver que se associa a esta bebida faz dela o índice por excelência da condição humana. Intimamente ligada ao estatuto de pessoa, a cerveja deriva da cultura e não da natureza: ela

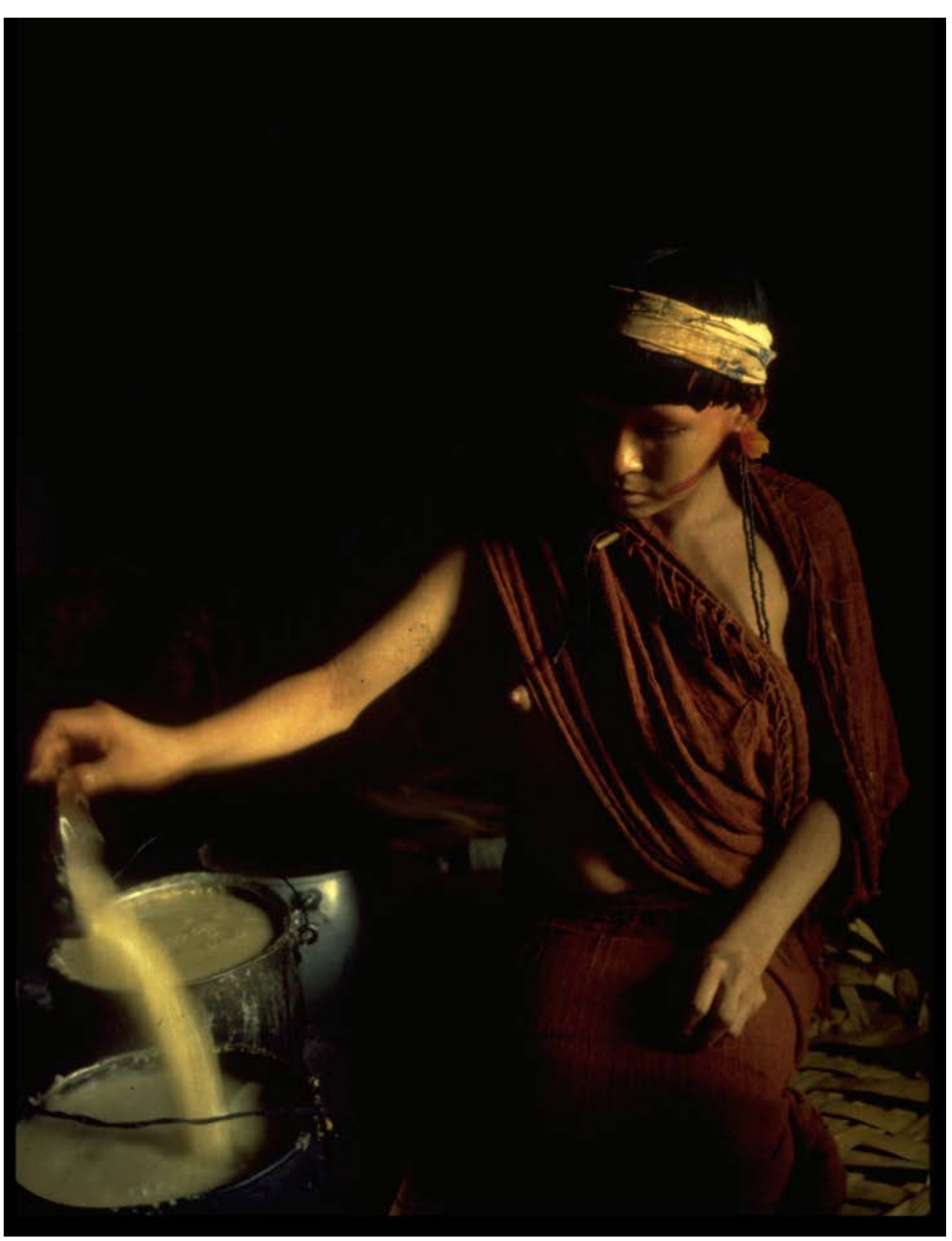

Figura 6

Jovem mulher preparando a cerveja de mandioca, população araweté (1981-1983). Foto de Eduardo Viveiros de Castro. "Esta bebida representa as relações, os gestos e os sabores que fazem o humano". 
é parte pressuposta do regime alimentar obrigatório de um sujeito, e é por isso que ela se encontra sob uma ou outra forma em todas as "naturezas" (fig. 6). Mas como sujeitos idênticos podem viver em naturezas distintas? Para compreendê-lo, devemos nos debruçar sobre as maneiras por meio das quais os povos indígenas da Amazônia pensam a diferença entre os corpos. Os membros de cada uma das espécies que compõem o mundo têm, segundo entendem, uma forma comum de "fazer sujeito"7 ou, dito de outro modo, de ser humano em face de seus congêneres. Do ponto de vista dos papagaios, por exemplo, seus corpos, seus pensamentos, suas emoções e seu regime de vida - alimentar e social - são idênticos ao que os humanos percebem em si mesmos quando se observam. Entretanto, se há apenas uma forma de ser uma pessoa, existe incontestavelmente uma multidão de corpos: o das cotias, o dos mosquitos, o das araras, o dos jaguares, em suma, o conjunto daqueles encarnados pelas diferentes espécies.

A diferenciação física entre sujeitos virtuais - todos semelhantes por definição - é o grande assunto da mitologia ameríndia. Ela postula a existência, no início, de uma única coletividade na qual se encontravam reunidos humanos, animais e plantas, mais exatamente o conjunto de "pessoas" virtuais antes de sua diferenciação corporal. Notemos, porém, que essas "pessoas" já possuíam algumas das características de seu estado futuro enquanto animal ou planta (por exemplo, tal pássaro já falava com uma voz cuja qualidade sonora evoca seu futuro canto), como se todos encobrissem já em potência a sua aparência e suas características de espécie, em suma, seu corpo específico. Não obstante, neste estado pré-natural encenado nos mitos, todos os existentes se acham ainda unificados por esse compartilhamento de uma humanidade comum, "humanidade" sendo aqui sinônimo de cultura. As narrativas contam como, na sequência, geralmente em razão de um incidente banal, essa comunidade se fragmentou, à medida que as diferentes espécies foram adquirindo sua forma e perfil etológico e se fecharam em si mesmas sem mais poder comunicar-se entre si e nem perceber-se como semelhantes, salvo em circunstâncias excepcionais. Após a dissolução desse coletivo primordial, as "culturas" de cada espécie tornam-se incomensuráveis, ao mesmo tempo sendo, do ponto de vista dos membros de cada espécie, sempre semelhantes. Elas se tornam herméticas umas às outras, porque estão associadas a regimes corporais ou a habitus etológicos distintos, isto é, a maneiras diferentes de habitar o mundo e portanto de percebê-lo. A "natureza" a que um corpo dá acesso é assim determinada por sua própria "fisicalidade": cada corpo corresponde a um ambiente ao mesmo tempo físico e social - um mundo vivido qualitativamente diferente. Cada espécie vive em um meio configurado para e pela sua dosagem de disposições, a qual depende, por sua vez, dos recursos corporais criados pela especiação. Em outras palavras, a sociabilidade carac-
7 [Nota da Tradução] No original francês, "faire sujet", que corresponde a algo como "tornar-se sujeito", "constituirse como sujeito" ou "ocupar a posição de sujeito". 


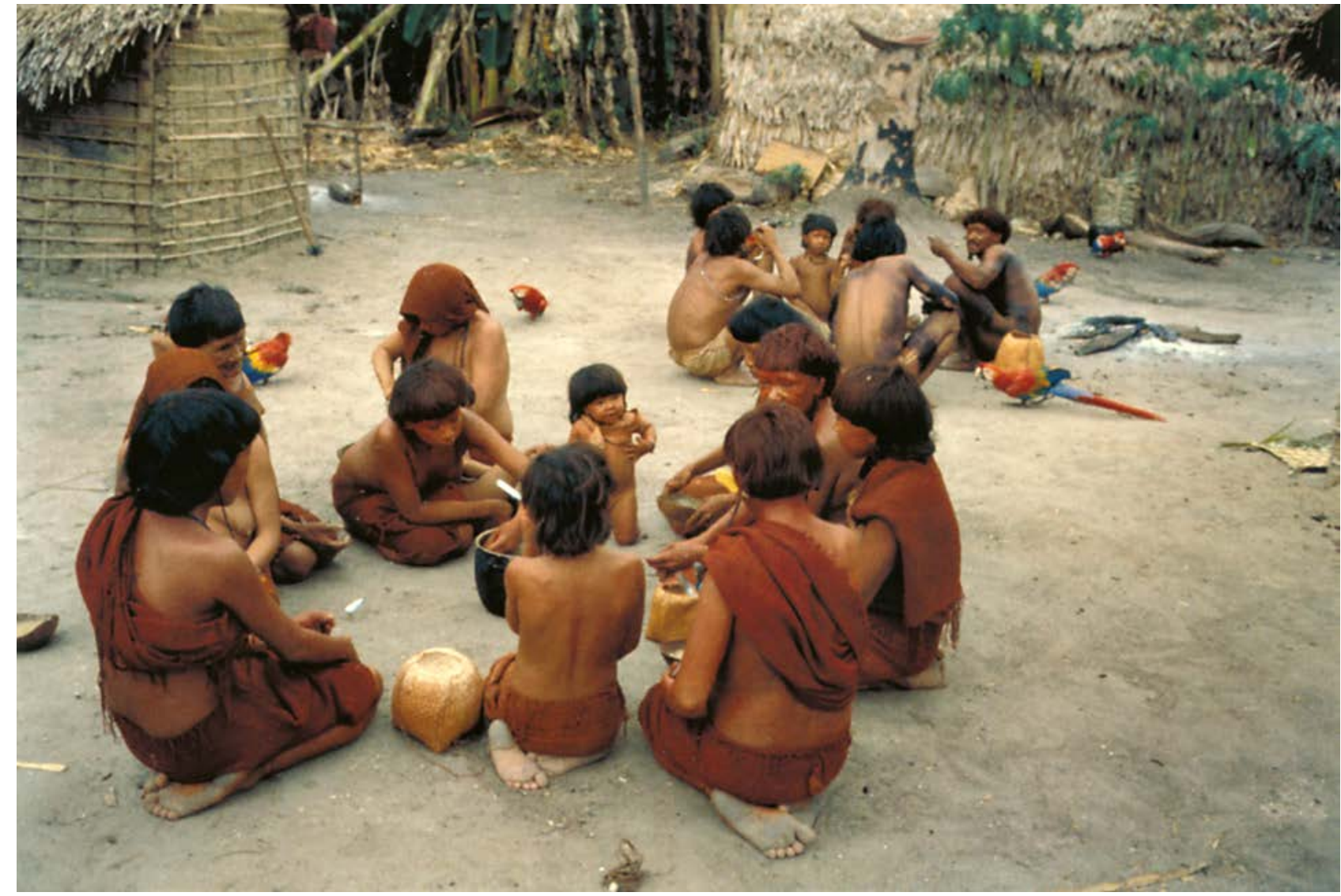

terística de todo sujeito virtual se realiza de maneira diferente segundo as propriedades do corpo de que ele dispõe.

Uma pessoa-jaguar vive em uma natureza diferente daquela de um sujeitocotia porque seu mundo é "colorido" pela maneira com que ela se articula a seu ambiente e aos outros seres e, sobretudo, pela intensidade da disposição predadora inscrita em seu corpo. Esta é certamente comum a todos os sujeitos, por princípio - todos os sujeitos animados devem alimentar-se -, mas ela não é distribuída de forma igual entre os existentes, variando em potência segundo a natureza dos corpos.

No ponto mais baixo da escala dos animados, os povos indígenas situam as espécies de pequeno tamanho, pobres em sangue e desprovidas de "armas", isto é, de ferrão, veneno, garras ou caninos; frequentemente são espécies gregárias, que formam bandos de indivíduos pouco diferenciados - por exemplo, um cardume de lambaris ${ }^{8}$, um enxame de borboletas, certas variedades de tubérculos. Se não são poderosos predadores, os corpos dos animais situados abaixo na escala têm todavia outras competências: em particular, a capacidade de "fazer massa" de forma coordenada (o que os predispõem a servir de modelo de certas formas de ação coletiva) ou, ainda, de "fazer família"9. É o caso, por exemplo, dos corpos das araras ou dos papagaios. O juízo feito sobre a vida social destes pássaros repousa sobre a observação de carac-

Figura 7

Grupo de índios, população araweté (1981-1983) Foto de Eduardo Viveiros de Castro.

"O grupo local é concebido como uma espécie natural, e cada espécie é uma família. Membros de coletivos diferentes podem, entretanto, mudar de 'sociedade' por adoção ou familiarização. É o caso dessas araras, integradas ao grupo indígena".

\section{8 [Nota da Tradução]}

A expressão francesa utilizada no original, "le menu fretin", designa pequenos peixes que o pescador geralmente rejeita na água, ou são utilizados para fritadas, como restos da pesca.

9 [Nota da Tradução] No original francês, "faire masse" e "faire famille". Conferir nota 6. 
terísticas etológicas dessa espécie: machos e fêmeas formam casais inseparáveis e duráveis, voam sempre em par e se ocupam diligentemente de seus filhotes. Esses traços levam os índios a ver na vida social dos papagaios uma "cultura" não tão diferente da deles, mas simplesmente mais bem-sucedida sob certos aspectos específicos ou certos domínios (fig. 7). Na outra extremidade da cadeia das formas corporais se encontram os espíritos imortais, tais como os deuses canibais dos Araweté, que se alimentam de humanos mas são eles mesmos invulneráveis e eternos. Logo abaixo desses devoradores supremos vêm os grandes predadores solitários e fortemente individualizados - felinos, sucuris, águias, serpentes venenosas - e os seres humanos, em sua qualidade de caçadores e guerreiros. Certos seres encarnam por contraste uma corporeidade patológica, ao mesmo tempo que ilustram pela negativa a invariância da personitude cultural. Fruindo de certa forma de consciência, essas criaturas estão condenadas a serem associais e solitárias, encarnando a natureza aberrante de um ser animado "não pessoa", privado de laços com um coletivo. Isso é muito frequentemente associado aos mortos recentes.

Em resumo, se a configuração relacional que constitui o humano é única, os corpos suscetíveis de ocupar a posição de humano são múltiplos. Os ameríndios dispõem como horizonte de pensamento um tempo e um lugar em que todos os sujeitos tinham acesso a toda a gama de recursos corporais, em que cada um dispunha de um corpo "totipotente" e consequentemente de uma mesma Natureza. Veio a especiação, e cada classe de seres herdou um fragmento apenas desse corpo primordial todo-poderoso, fragmento condensado em um corpo de espécie particular, articulado a um mundo também particular. Esse evento fundador do mundo atual, o da experiência corrente, é uma maldição aos olhos dos amazônicos, porque ele limita desde então a uma espécie apenas os recursos e as virtualidades de ação inerentes a tal ou qual forma de corporeidade. Assim, desde o ponto de ruptura evocado nos mitos, cada corpo de espécie representa apenas uma modalidade de ser-nomundo dentre todas aquelas possíveis. A perda que assombra o universo dos povos indígenas é aquela das virtualidades de existência que lhes oferecia um corpo mítico anterior à especiação, um corpo que sintetizava as propriedades de todos os corpos de existentes possíveis. Daí deriva seu apego fervoroso aos adornos feitos de elementos de corpos de animais: adornar-se é reencontrar uma parcela de uma experiência do mundo associada a tipos de corporeidade dos quais eles estão desde então excluídos na vida ordinária; coroar-se de plumas é reconectar com as aptidões especiais dos corpos de arara a exercer a conjugalidade ou a vida doméstica; suspender no pescoço um colar de garras ou dentes é dotar seu corpo de um eco dessa energia mortífera própria de um corpo de jaguar. 


\section{Espécies fixas em número limitado, mas uma infinidade de imagens de espécies}

A inflexão particular que o perspectivismo imprime ao animismo ameríndio tem uma implicação que deve ser sublinhada. Não existem nesse mundo categorias ontológicas fixas, à parte aquela de "sujeito de cultura". O que aparece como um queixada para tal tipo de sujeito aparece como um humano para outra classe de sujeitos; o que é jaguar para uns, é animal de caça para outros; e assim por diante. Na falta de um ponto de vista transcendente e de uma Natureza independente da ação humana que permitissem fixar os existentes em uma identidade imutável, eles migram de forma e de identidade em função de quem os percebe. Por exemplo, não existe o Rato de maneira absoluta, tal como ele seria fixado pelo olhar de Deus ou da ciência. Certamente, a "roupa-rato" - a virtualidade de uma atualização de existência sob a forma de rato-é um dado do mundo presente desde sempre. Os povos amazônicos não concebem uma Natureza suscetível de criar novas formas de ser sem nunca se esgotar; a variabilidade de naturezas possíveis é, de direito, limitada.

À primeira vista, portanto, a maioria das sociedades dessa região privilegia uma concepção fixista do universo, em que as particularidades das espécies existem desde sempre e não necessitam explicação quanto a sua origem. Certamente, as araras eram no tempo mítico pessoas para os jaguares e vice-versa, mas a forma "arara" já existia, ela não nasceu no momento no qual as araras tornaramse pássaros aos olhos de outras espécies. Não é tanto a aparição das formas das espécies (ao modo das Just So Stories, de Rudyard Kipling, que contam como cada animal obteve sua morfologia) que deve ser explicada ou que mobiliza os mitos, mas, antes, a ruptura do coletivo no qual todos os sujeitos se percebiam uns aos outros como humanos e as consequências dessa fragmentação: a perda de uma linguagem comum, a percepção de outrem com um corpo de não humano, a diferenciação das perspectivas. Os povos indígenas amazônicos não concebem que formas inéditas possam nascer, seja delas mesmas, seja de outras pré-existentes. Tudo que pode ser já existe, com uma forma específica. As "naturezas" implicadas pelos diferentes corpos não divergem senão pela distribuição de seus elementos, não pela característica dos elementos eles próprios.

A gama de seres que se oferece à percepção de maneira virtual ultrapassa largamente, entretanto, aquela que se oferece aos sentidos dos humanos em contextos ordinários. Essa disjunção entre, por um lado, a ideia de um número finito de formas de espécies e, por outro lado, a de uma proliferação de formas percebidas pode-se esclarecer por meio de uma analogia com o jogo de xadrez. No xadrez, as peças postas em movimento são limitadas, e assim também os espaços suscetíveis de serem ocupados por cada figura. Em contrapartida, as combinações - as relações - possíveis entre elas são praticamente infinitas. Da mesma forma, existe 
um estoque fechado de espécies, mas as relações possíveis entre esses corpos-e, portanto, as percepções (recíprocas ou não) implicadas por essas relações - são inumeráveis. Há apenas uma forma "rato", mas um rato pode assumir, em face de outrem, muitas formas de aparência corporal distintas em função do tipo de interação que se estabelece entre dois parceiros. Na "natureza" de um gafanhoto, um rato (supondo que ele se alimente desses insetos) ocupará a função - e a aparência - "jaguar". Na natureza de uma jaguatirica, ele será "queixada", e, na de um humano, "rato". Em relação às populações de espíritos com que coabitam numerosos grupos amazônicos, estas possuem uma suprema capacidade de assumir corpos diferentes: no mínimo, a aparência sob a qual elas se manifestam aos humanos e aquela sob a qual elas aparecem para si mesmas, à qual caberia ainda acrescentar a aparência que elas tomam em face de outras classes de espíritos, que estes, por sua vez, veem sob outras formas possíveis de encarnação, e assim por diante ${ }^{10}$. Os índios exprimem essa ideia falando dos corpos não humanos como de "roupas" que os existentes podem vestir ou despir em função das interações em que estão envolvidos. Para retomar o exemplo do jaguar, ele se despe de seu corpo-roupa para revelar um corpo humano quando se junta aos seus congêneres. Dito de outro modo, quando um jaguar se acha entre seus semelhantes, que lhes despertam amistosidade, ele deixa de ter a corporeidade raivosa da forma-jaguar sob a qual suas presas potenciais o apreendem. As imagens engendradas por perspectivas diferentes daquelas ocupadas pelo observador na origem do olhar são parcialmente visíveis por este observador. Elas aderem à forma percebida à maneira de uma conotação ou de um eco. Detectáveis na pupila, no reflexo ou na sombra de um corpo, desveladas em sonho ou em outros estados alterados de consciência, essas percepções oriundas de outros corpos representam uma dimensão "oculta" dos seres. Enganados pela semelhança superficial entre o dualismo perspectivista dos índios - todo ser pode portar em si o fantasma do que ele é para um outro olhar e seu próprio dualismo da carne e do espírito, os missionários (e, no seu encalço, frequentemente os etnólogos) apressadamente assimilam essa dimensão à alma. $\mathrm{Na}$ realidade, os termos indígenas que a designam remetem a algo totalmente diferente de um princípio espiritual interior, oposto ao corpo, tal como implicado em nossa noção de alma. Eles se referem, antes, a essa parte invisível própria de todo existente, mais precisamente à aparência que o corpo de um sujeito tem para um ser diferente do enunciador-testemunha. A forma (humana) sob a qual um queixada se apresenta a outro queixada constitui, assim, do ponto de vista de um humano, a "alma" do queixada; ao mesmo tempo, a "alma" de um humano é a imagem que ele oferece aos seus congêneres tal como ela seria vista por um predador de humano - espírito, animal ou, ainda, pela "alma" de um outro humano. Compreende-se a partir disso por que a fotografia constitui um dispositivo desconcertante para numerosos indígenas da Amazônia, na medida em que ela introduz
10 [Nota da Tradução] O texto original faz menção nesse ponto à figura "Máscara de espírito, população jurupixuna" presente no acervo do Museu da Universidade de Coimbra, Coleção Rodrigues Ferreira. Não foi fornecida autorização para publicação dessa imagem, de modo que remetemos o leitor ao texto original para acesso a ela. A legenda da imagem no texto original dizia: "Dependendo do ponto de vista, o mesmo ser pode ser percebido com um corpo diferente, como ilustra esta máscara bifacial". 
uma visão "terceira" - aquela da lente focal - entre o sujeito da percepção e o corpo percebido. A fotografia não é - não seria isso senão em razão de uma mudança de escala - a visão "natural" que tem de uma outra pessoa aquela que fotografa; por isso, ela convoca um fantasma, aquele do sujeito indefinido e invisível do qual ela reflete um olhar "outro".

Em suma, a "alma" indígena é formada pela perspectiva de ou-

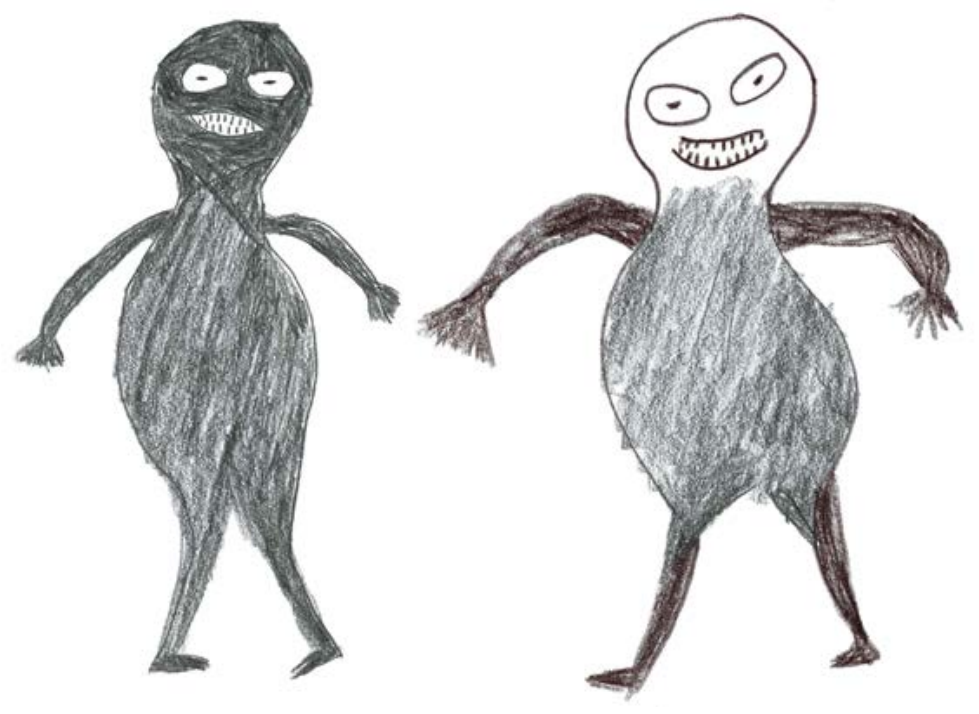
trem. Daí a prevalência na Amazônia de espíritos que se desdobram eles mesmos em "alma" e "corpo", como é o caso entre os Wauja do Xingu, em que os espíritos têm, ao mesmo tempo, "roupas" que lhes permitem aparecer sob tal forma a certo tipo de observadores em determinados contextos - por exemplo aos humanos, durante rituais - e um "corpo" que constitui sua forma para outros observadores - por exemplo, seus congêneres (figs. 8 e 9). O fato de que uma "alma" pode ter um corpo, ele mesmo multiplicado em um novo par de alma e de corpo, e assim por diante ad infinitum, mostra bem que o que está em jogo é a virtualidade sempre presente a partir de uma perspectiva outra, e não uma entidade essencialmente distinta do corpo. Aos olhos dos povos amazônicos, de fato, o "corpo" é tão imagem quanto a "alma", e esta é tão material quanto aquele; essas duas dimensões estão em uma relação reversível, análoga àquela entre fundo e forma, e a única coisa que as distingue é o ponto de vista incidente sobre elas.
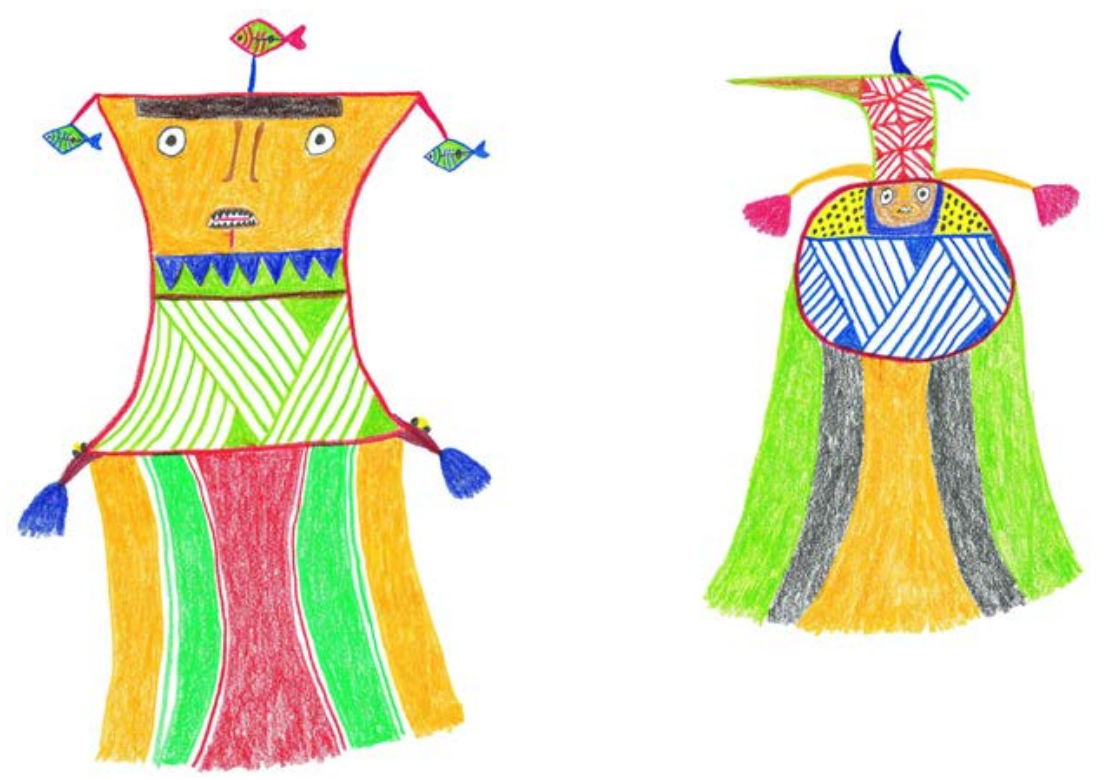

Figura 9

Máscaras dos espíritos Ajatualu nau e Talau kumã. Desenho de Ajoukumã Wauja, 1998, crayon sobre papel, $44 \times 32 \mathrm{~cm}$. Coleção Etnográfica Aristoteles Barcelos Neto (AJO.1998.028.393). Foto de A. Barcelos Neto. "Este desenho restitui a aparência revestida por uma população de não humanos. As 'roupas' de espíritos foram desenhadas com muito mais precisão que os seus 'corpos"'. 
Para inventariar todas as formas dos existentes, seria necessário, portanto, adicionar as naturezas percebidas por todas as criaturas possíveis, uma totalização na verdade inconcebível, já que não é possível fechar a lista dos sujeitos outros capazes de engendrar novas perspectivas e, portanto, novos existentes. Assim, o perspectivismo constitui um tipo de criacionismo sem autor, combinando uma visão fixista do universo - nenhuma nova forma pode nascer - com uma concepção que admite a proliferação de formas virtuais derivadas da extensão infinita de pontos de vista possíveis.

\section{Fabricar o corpo humano}

O corpo humano é um efeito relacional: perceber o outro sob a forma de um ser humano equivale a compartilhar com ele uma posição de sujeito, o que supõe o reconhecimento de uma identidade entre si e o outro. O que tal julgamento de identidade implica? Para os índios da Amazônia, a resposta é simples: um corpo de humano é a expressão material de uma relação entre semelhantes; o corpo humano não é uma "roupa de espécie" como as outras; de fato, ele não é nada mais que a forma padrão de um sujeito enquanto membro de uma "sociedade". Nos mitos de cosmogênese, lembremos, o estado inicial dos sujeitos reunidos no coletivo primordial único - aquele que precede a especiação - é o estado humano. A humanidade é uma modalidade de existência aberta a todos os seres animados suscetíveis de fazerem sujeito, e não uma forma ligada de maneira estável e unívoca a uma espécie particular. Entretanto, a visão amazônica da humanidade como um efeito de perspectiva ligada à qualidade de uma relação - antes que como um atributo essencial - não impede de maneira nenhuma os grupos indígenas da Amazônia de se conceberem como espécies, enquanto tribos dotadas de uma identidade própria. Se os "humanos" enquanto tais não constituem uma espécie, os índios reconhecem perfeitamente que, ainda que os atributos de cultura sejam idênticos em toda parte, eles mesmos e outras nações indígenas ou não indígenas praticam a arte natural de viver juntos de maneira diferente. Essa variação, segundo eles, se explica facilmente: assim como as araras e os queixadas se alimentam e se comportam de forma distinta, embora sejam humanos da mesma maneira, os índios de um dado povo e aqueles de outro povo têm costumes divergentes porque pertencem a espécies distintas (diríamos sociedades), ou, dito de outra forma, porque possuem corpos diferentes. Essa variação corporal se dá a ver por meio das variações na vestimenta, nos adornos, nas marcas e pinturas corporais. Tais diferenças, que para nós são de ordem cultural, traduzem do ponto de vista indígena um processo de especiação. Assim, os membros de um dado coletivo vestem "por cima de" sua forma humana, e em continuidade com ela, o equivalente a uma "roupa de 
espécie" composta de elementos que são ao mesmo tempo marcas de identidade e índices de disposições relacionais valorizadas pelo coletivo.

A especificidade da corporeidade humana está ligada aos procedimentos pelos quais ela é fabricada: a carne e a forma do corpo são a memória literalmente encarnada das interações afetivas entre o sujeito e seu entorno. Ao invés de ser dada, como é o corpo de uma espécie natural, a forma humana do corpo é inteiramente produzida: ela é o resultado de uma ação intencional e coletiva. Um indivíduo não vem ao mundo como humano; ele se torna humano por meio da alimentação e dos cuidados dispensado por seus parentes, do zelo que estes demonstram entre si. Ao participar do crescimento do feto pelo dom de alimento na forma de seu esperma, um homem adquire em face de uma criança o estatuto de "pai". Ele se torna literalmente seu pai à medida que a própria criança se torna "filho" ou "filha" desse homem. Oferecer regularmente alimento a outrem com sinais de afeição é um comportamento típico de congênere; é fonte de uma relação de parentesco. Isso exprime uma disposição em pensar em seus próximos, particularmente quando estão ausentes, evocando-os por meio de imagens mentais que suscitam ternura, desejo e saudade. Essa atitude mental, aliás, constitui a forma primeira da reflexão nas culturas indígenas: "pensar" é antes de mais nada pensar nos seus próximos, por oposição ao exercício especializado do pensamento especulativo, o qual remete ao saber. Em suma, o parentesco não é dado por um laço biológico que lhe precederia: ele se constitui na construção mútua de uma corporeidade compartilhada, depositária de uma consciência corporal feita de uma memória de interações com os seres, os lugares e os objetos familiares (fig. 10).

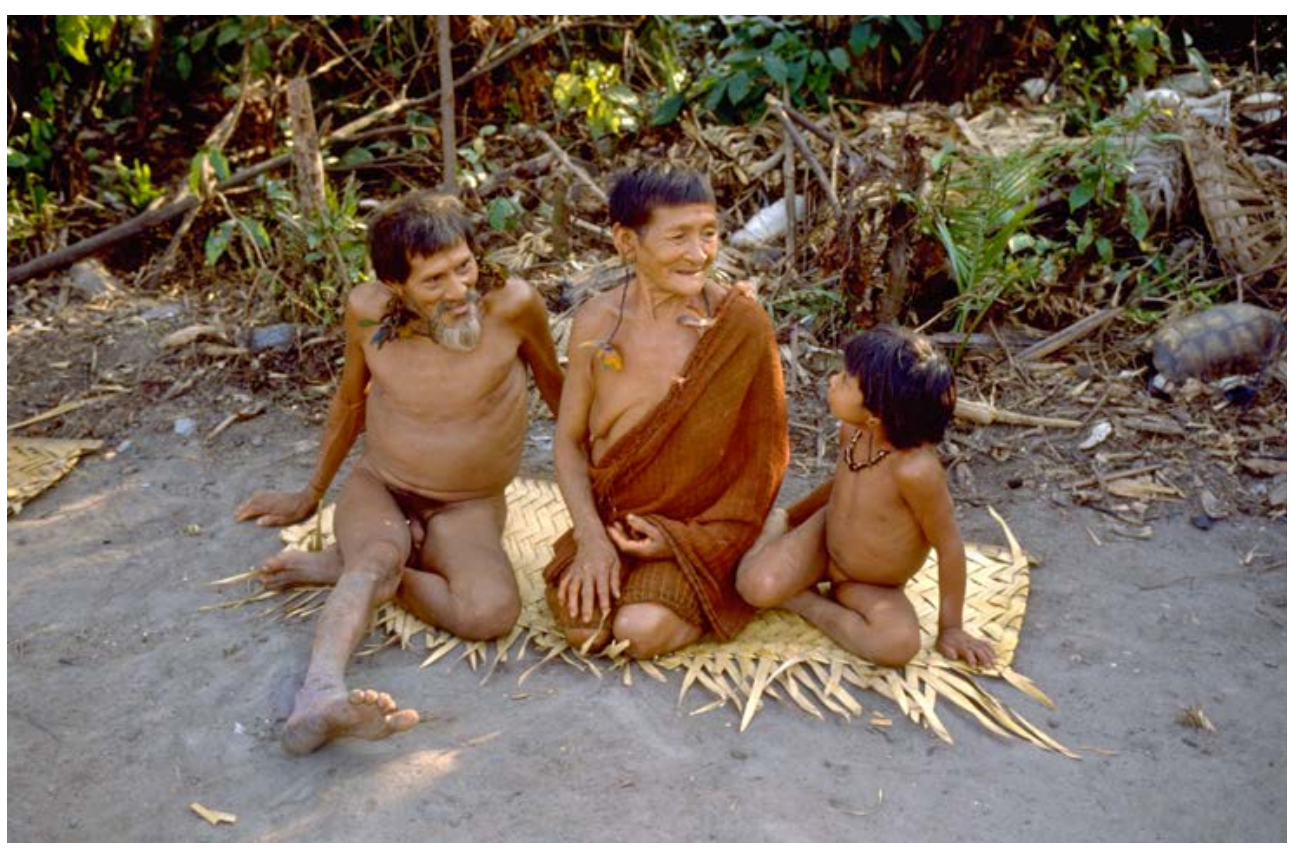

\section{Figura 10}

Uma criança e seus avós, população araweté (1981-1983). Foto de Eduardo Viveiros de Castro. "Trata-se de fabricar corpos semelhantes e de tornaremse parentes pelo olhar e pela atenção recíprocos". 
O dom de alimento, mas também o olhar, desempenham um papel central nesse processo, em função de uma lógica que assimila estreitamente o alimento oferecido, a relação entre pessoa provedora e sujeito alimentado, e o olhar mútuo, eixo maior da relação de intersubjetividade. Comeré, portanto, incorporar uma relação - especialmente visual - ao mesmo tempo que se incorpora uma substância; esta assimilação justifica a afirmação desconcertante dos Waiwai, segundo a qual é olhando suas crianças que eles as fazem crescer. Em outros grupos amazônicos, a ênfase se situa antes nas manipulações e nos contatos corporais: o corpo do bebê é massageado e modelado segundo técnicas diversas, assim desenvolvendo uma carne especificamente humana ao absorver as relações de proximidade afetiva pressupostas nessas práticas. A mesma lógica subjaz à aplicação de motivos de pintura corporal sobre o corpo de um próximo, como um filho ou cônjuge: na medida em que remete a essas relações e a suas dimensões qualitativas, o desenho é o ícone de uma carne socializada, modelada pelas relações com os congêneres (fig. 11).

A "humanidade" é, em suma, o atributo de um corpo produzido em conjunto por um coletivo de indivíduos definidos como parentes, como semelhantes ou como congêneres - aqui, os três termos podem ser tomados como sinônimos em virtude de seu engajamento nesse trabalho. Essa fabricação conjunta da matéria e da consciência corporais - ao mesmo tempo que de parentesco - é o que na Ama-

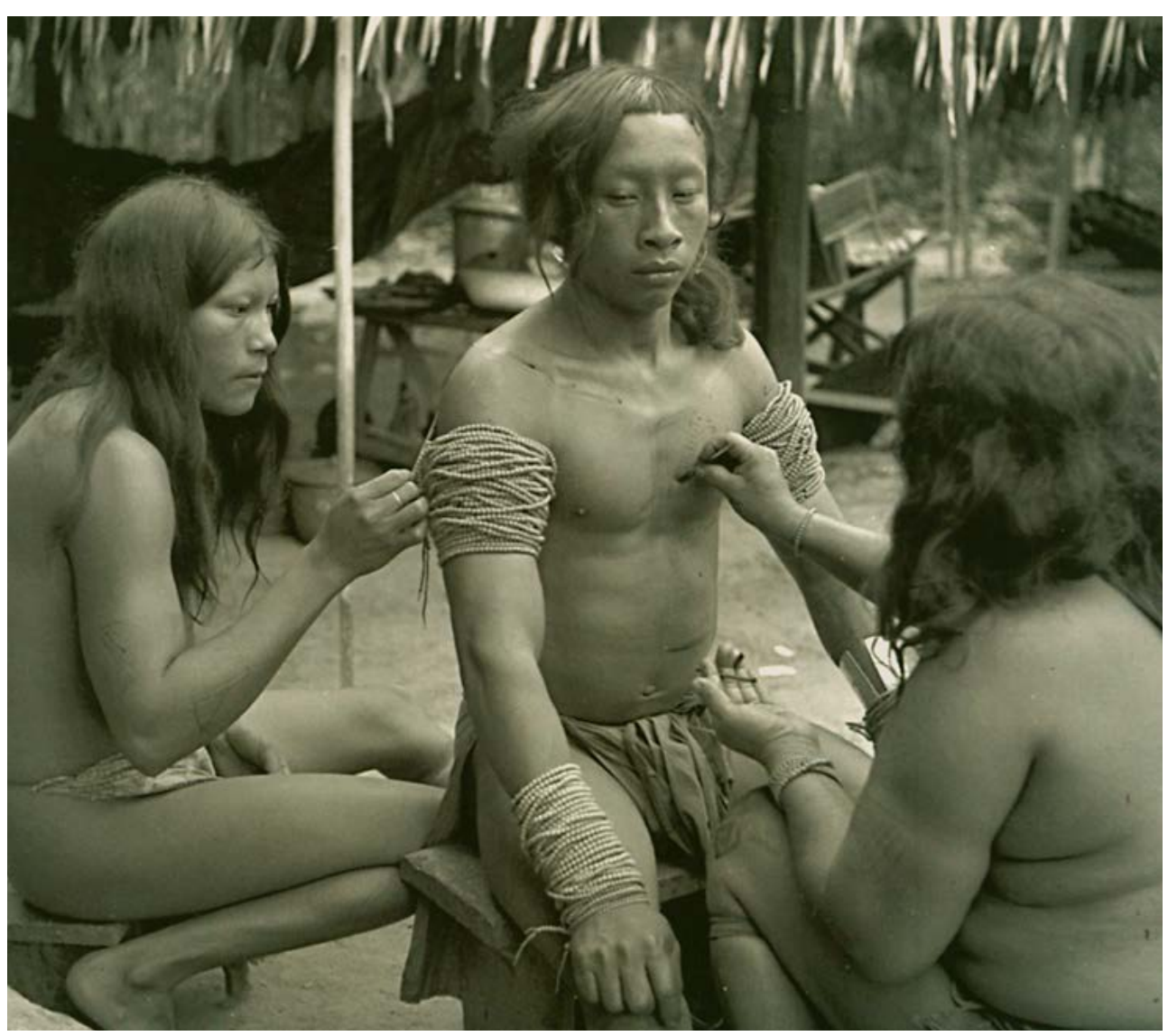

Figura 11

Homem jovem pintado por sua mãe e sua esposa, população wayana (1965).

Foto de Jean-Marcel Hurault. "É-lhe dado um corpo humano desenhando as marcas específicas da sociabilidade". 
zônia se assemelha mais ou menos a uma atividade de produção, no sentido ocidental do termo. Em contraste com a manufatura de bens materiais (ou dos meios de os produzir), que é para nós o modelo da ação valorizada, os ameríndios investem seus esforços em um outro trabalho: confeccionar pessoas. O corpo humano é a coisa mais valorizada nesse universo porque ele materializa a sociabilidade e, também, porque ele é testemunho de uma capacidade de ação - fabricar viventes semelhantes ao fabricador - percebida como própria do humano. As intenções e os afetos imbricados no trabalho parental de produção de corporeidade humana estão condensados nos adornos e nas pinturas que recobrem o corpo. Os ornamentos são os atributos obrigatórios das "pessoas verdadeiras": eles assinalam a presença de um corpo plenamente humano, isto é, fartamente dotado de recursos corporais variados e, portanto, de possibilidade de interação com outrem.

Como essa aptidão para fabricar o humano se articula com a intencionalidade predadora própria a todos os seres vivos? Ela é o inverso desta, sua face positiva, da mesma maneira que a troca matrimonial é o inverso da proibição do incesto. Longe de se oporem, "pulsão predadora" e "pulsão parental" são indissociáveis: num mundo governado pelo esquema da predação, quanto mais "amamos" nossos parentes, quanto mais os representamos mentalmente, quanto mais participamos do seu crescimento e de seu bem-estar corporal, mais intensas também são a "raiva" que experimentamos contra aqueles que os ameaçam de predação e a "fome" por aqueles de que nosso próprio coletivo se alimenta. Predação e produção, disposição de destruir o outro e de engendrar semelhantes se entrelaçam tão bem que as duas capacidades aparecem uma como a condição da outra (fig. 12): a fecundidade pressupõe a aptidão para a predação, o homicídio confere um acréscimo de potência produtiva.

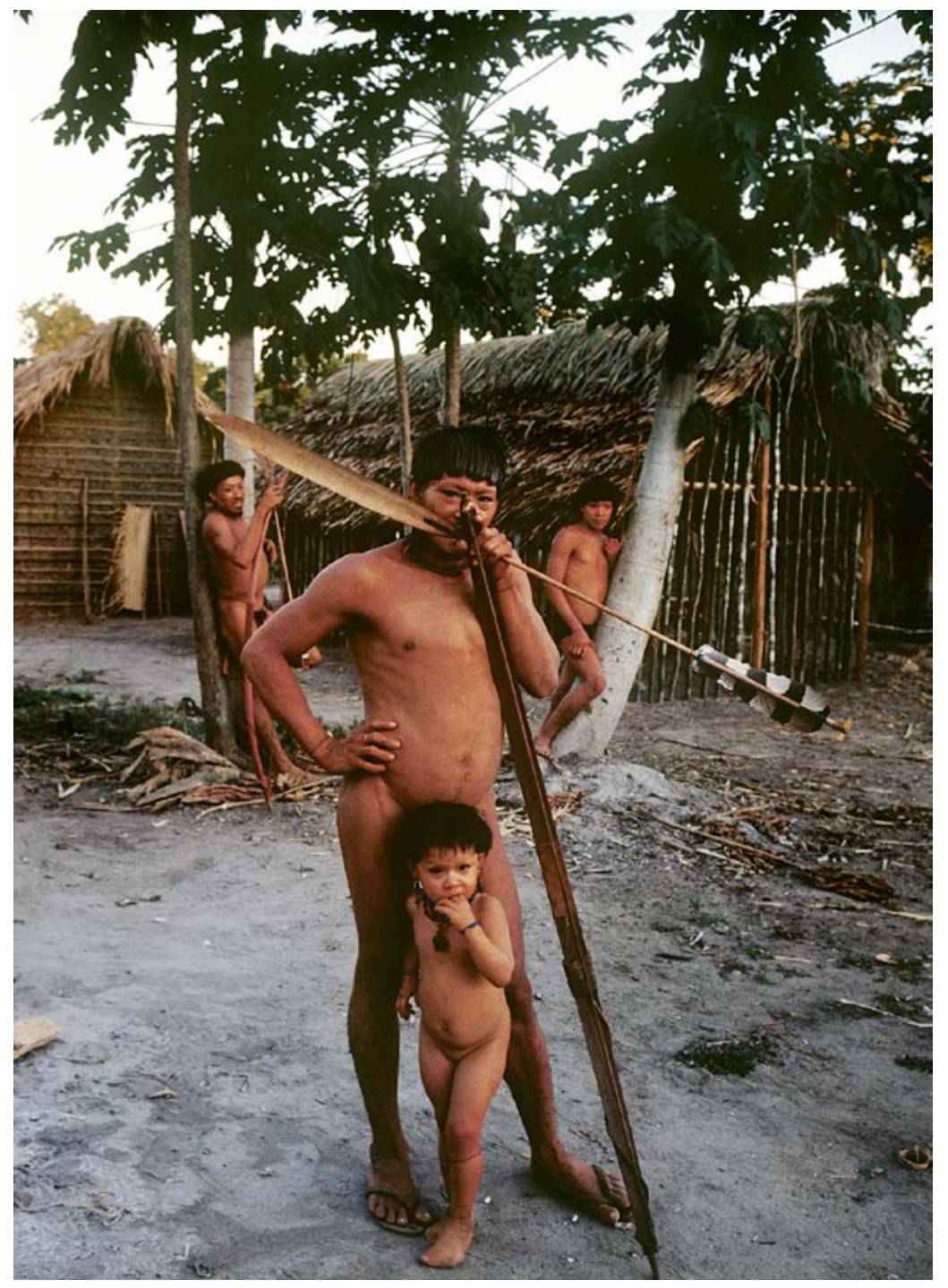




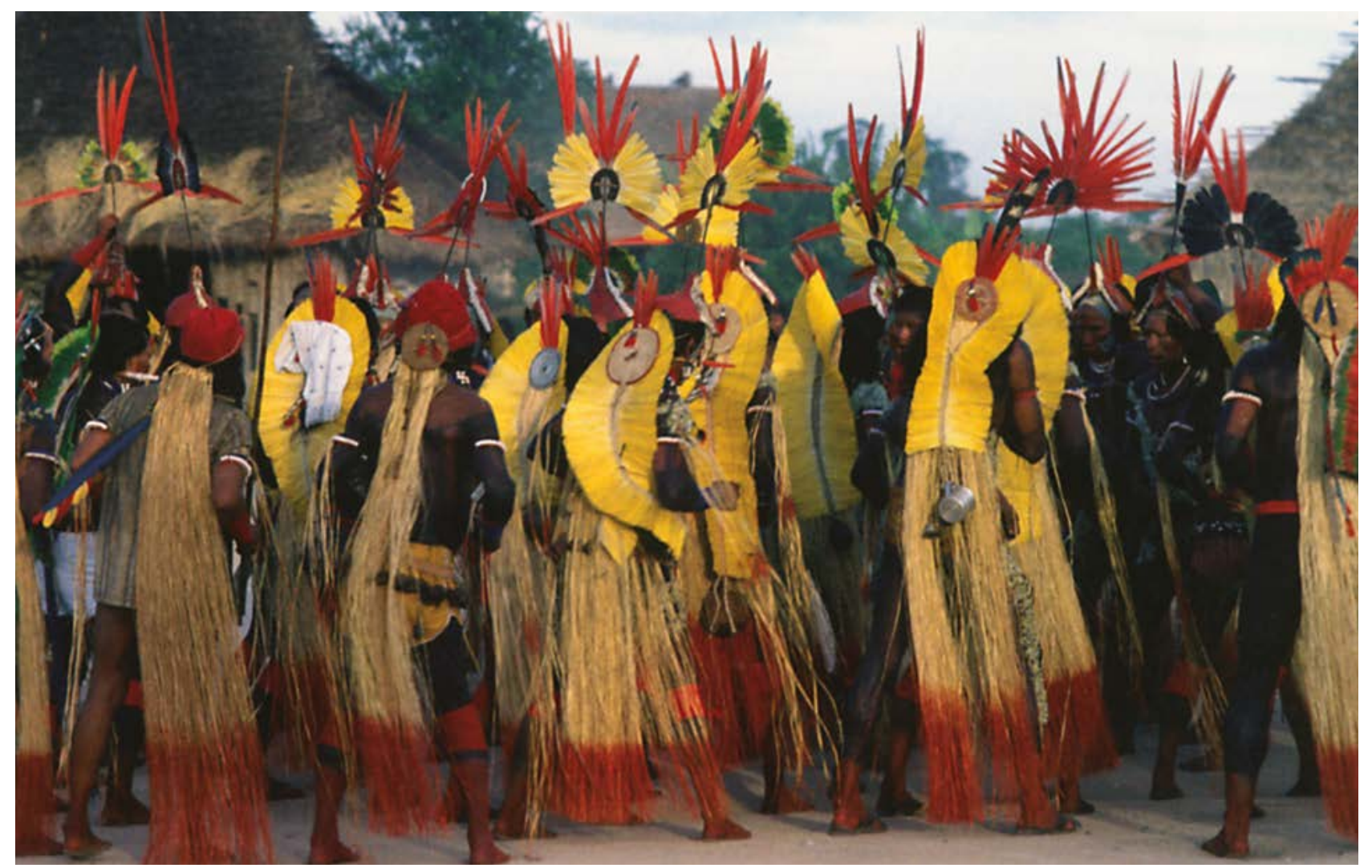

"Os Bororo são araras"

A ornamentação corporal, que distingue simultaneamente o humano e o membro de um coletivo específico, empresta seus signos principalmente do mundo animal. Ela privilegia três tipos de materiais: plumas; superfícies irisadas; dentes e garras. Cobrindo seus corpos de plumas, homens e mulheres mostram que possuem as aptidões para a conjugalidade ou a "parentalidade" tal como certos pássaros a manifestam: dançando coletivamente com uma mesma "roupa de espécie" feita de penas de arara, esses Kayapó do Brasil Central (fig. 13) celebram sua capacidade de formar uma comunidade de semelhantes; ao escolher plumas amarelas em vez de vermelhas ou azuis, esses mesmo índios afirmam: "Aqui estão os corpos de tal espécie", por oposição àqueles da sociedade vizinha. Igualmente, ao ornar o peito dos homens com colares feitos de garras de jaguar, um dado povo torna visível a disposição, característica do ideal de masculinidade, em adotar a corporeidade de um predador. Assim, um corpo humano plenamente constituído aparece como um artefato híbrido feito de pedaços de corpos de espécies naturais, cada elemento condensando qualidades próprias à roupa particular da qual foi tirado. Esse corpo reúne aspectos de todos os corpos possíveis sem remeter ao de uma espécie em particular. Os cocares, os adornos de penas ou de dentes não têm somente uma função expressiva, a de evocar por metonímia os tipos de comportamentos emprestados dos animais, eles permitem igualmente
Figura 13

Dançadores executando uma coreografia ritual, população kayapó (1996).

Foto de Gustaaf Verswijver. "Um corpo verdadeiramente humano nos é dado ao nos vestirmos de pássaros". 
dotar os humanos da função de exibição e, sobretudo, de individuação que uma plumagem reluzente tem para muitas espécies de pássaros - especialmente para os machos. Centrada nas combinações de cor, na regularidade e na delicadeza do trabalho de composição, no aspecto furta-cor das penas e dos élitros, no brilho da penugem branca e das partículas de cascas de ovos coladas sobre a face, a estética é convocada para exibir a importância do indivíduo (e, por extensão, a do coletivo ao qual ele se liga) e, ao mesmo tempo, seu caráter único e singular. As superfícies peroladas ou translúcidas como o quartzo, as conchas ou as miçangas, iridescentes como as plumas ou as asas de besouros, são particularmente procuradas para evocar o brilho de um corpo (figs. 14 e 15). Combinados com diademas de penas brilhantes, esses adornos multicores são o equivalente à auréola dos santos na pintura cristã, exceto por remeterem a um estado extraordinário do corpo antes que a uma "interioridade" (uma alma) fora do comum.

Os atributos sensíveis das plumas - abundância de cores, dimensões e formas que elas oferecem - as predispõem também a um uso simbólico (figs. 16 e 17). Assim, certos grandes cocares circulares figuram a organização social de uma aldeia de "humanos verdadeiros" vista do alto - do ponto de vista de uma águia -, ao mesmo tempo que eles evocam a influência da "pessoa" detentora dessa perspec-
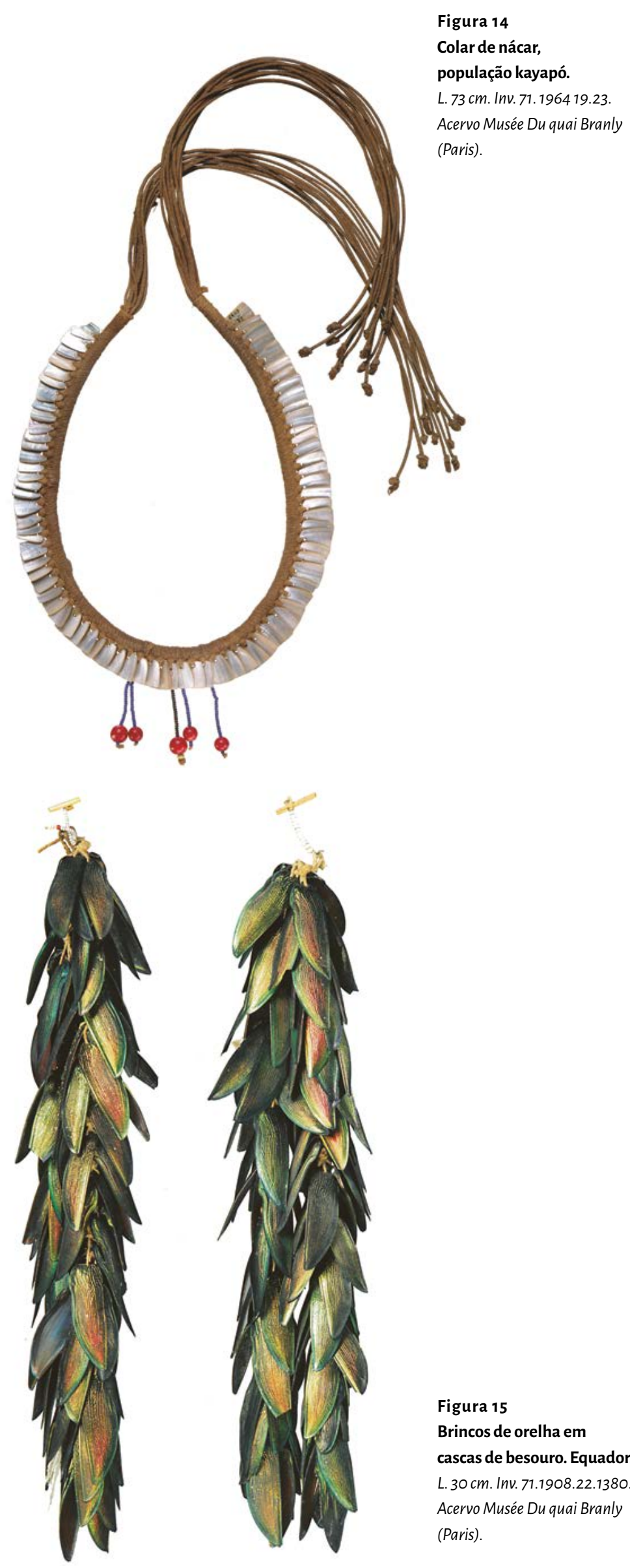

Figura 15

Brincos de orelha em cascas de besouro. Equador. L. $30 \mathrm{~cm}$. Inv. 71.1908.22.1380.1-2. Acervo Musée Du quai Branly (Paris). 
tiva celeste ${ }^{11}$. Igualmente, o estranho capacete de cera (chamado kutop) coroado, na extremidade de uma haste, por um pequeno diadema de penas de arara, utilizado pelos homens kayapó mekragnoti durante certos rituais, representa a vista que têm sobre as aldeias kayapó - e, de modo mais geral, sobre o mundo terreste - os Mekragnoti que ficaram no céu desde os tempos míticos. A haste simboliza a corda pela qual os Mekragnoti desceram na terra. Os cocares utilizados pelos diferentes grupos kayapó são, além disso, utilizados como brasão: cada grupo cerimonial, clã, metade ou classe etária possui um adorno específico - mais precisamente, o modelo exclusivo desse adorno -, e tal ornamento, ao mesmo tempo expressivo e produtor de uma corporeidade comum aos membros do coletivo, constitui um patrimônio ciosamente guardado. As coroas de plumas das sociedades do Nordeste amazônico também evocam corpos, neste caso os corpos dos seres primordiais. O grande cocar orok dos Wayana-Apalai é na realidade uma máscara antes que um adorno: considerado como a roupa - ou seja, o corpo - de um ser criador do tempo mítico, ele não é utilizado senão durante alguns rituais. Vestir tal traje significa de fato assumir uma parte da corporeidade de um ser sobrenatural, assim como as faculdades e as capacidades que Ihe são próprias (fig. 33).
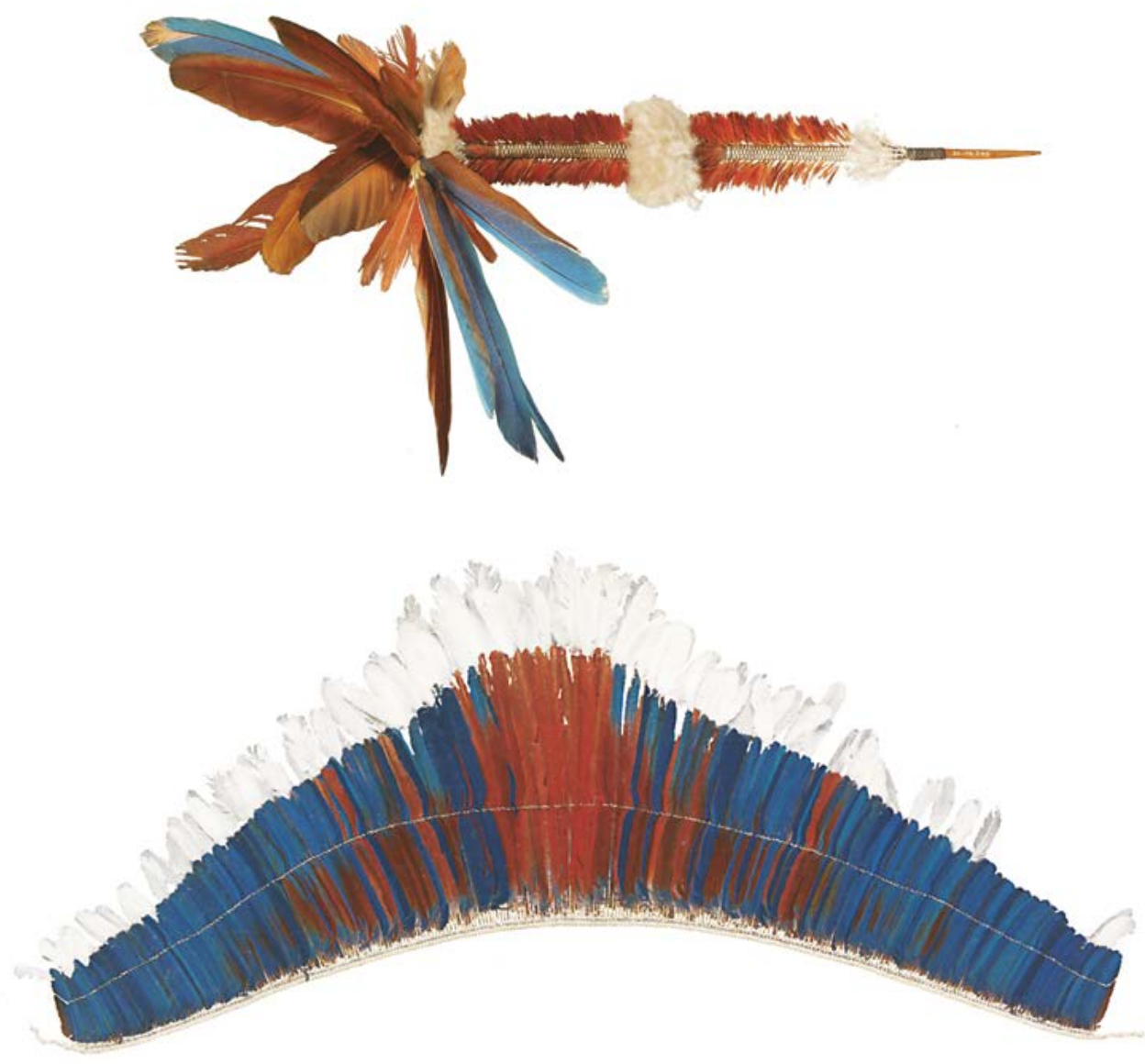

11 [Nota da Tradução]: O texto original faz menção nesse ponto à figura "Cocar, população karajá. A. 124 cm. Coleção Cid. Inv. 922" presente no acervo do Instituto Cultural Banco Santos. Não foi fornecida autorização para publicação dessa imagem, de modo que remetemos o leitor ao texto original para acesso a ela. A legenda da imagem no texto original dizia: "Este cocar é ao mesmo tempo uma 'roupa' de espécie, um brasão, uma figuração simplificada da organização espacial e social e um emblema de identidade pessoal".

Figura 16

Perfurador labial, população bororo.

A. $48 \mathrm{~cm}$. Inv. 1936.48.248. Acervo Musée Du quai Branly (Paris).

Figura 17

Cocar, população kayapó. L. $180 \mathrm{~cm}$. Inv. 70.2003.2.5. Acervo Musée Du quai Branly (Paris). 


\section{A pintura corporal: os corpos de espécie vistos do interior}

A pintura corporal é onipresente nas terras baixas da América do Sul. Utilizada de modo tanto cotidiano como em contextos rituais, tanto na paz como na guerra, sua aplicação e conceitualização são variáveis quanto ao grau de elaboração e de refinamento. Certos grupos ornam seus corpos combinando, segundo regras próprias, até cerca de quarenta motivos geométricos distintos, todos nomeados e reconhecidos (fig. 18). As combinações de desenhos e cores podem ser colocadas a serviço de uma sinalética social bem precisa: elas indicam não apenas os pertencimentos tribais, clânicos, de classe etária, de grupo cerimonial (como podem igualmente fazê-lo os adornos plumários), mas também o estado relacional no qual se encontra aquele que porta a pintura: viúvo há seis meses, pai de uma segunda criança com menos de 2 anos de idade, convalescente de uma doença de tal ou qual natureza, e assim por diante.

Mas a pintura corporal não é o apanágio dos únicos (verdadeiros) humanos. Do ponto de vista indígena, todos os seres suscetíveis de "fazer sujeito"12 inscrevem desenhos sobre o corpo: a pintura corporal faz parte da panóplia do humano. Assim, o que aparece aos humanos como a pele manchada de um jaguar é visto pelos congêneres do jaguar como motivos de pintura corporal humana. Se a constituição de uma carne e a percepção de uma forma humana se enraízam em uma relação de identidade entre congêneres - que é o mesmo que dizer em uma relação de parentesco-, a pintura corporal constitui,
Figura 18

Jovem mulher revestida de pinturas, população kayapó (1996). Foto de Custaaf Verswijver. "A pintura e o adorno de cabeça branco são a 'roupa' de espécie que designa e modela o corpo de certa classe de seres".

Figura 19

Criança revestida de pinturas, população parakanã (1985). Foto de Lux Vidal. Acervo LISA. "Os motivos com os quais esta mãe adorna o rosto deste bebê farão para ele um corpo feroz aos olhos de predadores invisíveis, mas um corpo de humano aos olhos de seus semelhantes".

12 [Nota da Tradução] Conferir nota 6 
juntamente com os adornos, a pele visível de um sujeito enquanto membro de um coletivo ou de uma espécie determinada. Todos os seres animados, potencialmente sujeitos, lembremo-nos, pertencem presumivelmente a um coletivo, a uma "espécie" necessariamente singular, dotada de uma "cultura-etograma" ela também singular; a pintura, e, de modo mais geral, a ornamentação corporal, é o condensado visual dessa cultura própria à espécie. Para retomar o exemplo do jaguar, o pelo manchado forma a roupa de espécie do jaguar da perspectiva "presa", isto é, tal como ele é visto por aqueles que come, enquanto as pinturas corporais sobre uma pele "humana" formam sua roupa de espécie na perspectiva "congênere". Elas são seu traje de sujeito-jaguar visto "de dentro", tal como ele é percebido pelos membros de seu coletivo (fig. 19).

De resto, os mesmos motivos estão presentes nos artefatos: a decoração geométrica das cerâmicas, da cestaria, dos tecidos pintados ou bordados representa quase sempre, de forma mais ou menos estilizada, as pinturas corporais dos espíritos ou dos animais (fig. 20). Mas esses motivos não reproduzem exatamente as pinturas corporais; fiéis a seu viés antifigurativo, os artistas indígenas buscam antes evocá-las por outros desenhos (e, às vezes, por meio de um nome ligado a um motivo) que copiá-las a partir de uma representação mental. $O$ papel da arte "decorativa" associada aos objetos funcionais é sobretudo o de desencadear processos de visualização: a imagem que conta é aquela que cada um faz mentalmente para si, não aquela materializada no grafismo. Este não é senão um meio de acionar uma forma de imaginação dedicada à representação de corpos sob todas as facetas possíveis. Uma função idêntica é atribuída ao traje de alguns animais: o caráter abstrato e labiríntico dos desenhos formados pela pele das serpentes, a plumagem de tal ave de rapina, a pelagem dos felinos faz dessas criaturas repertórios ambulantes de pinturas corporais virtuais.

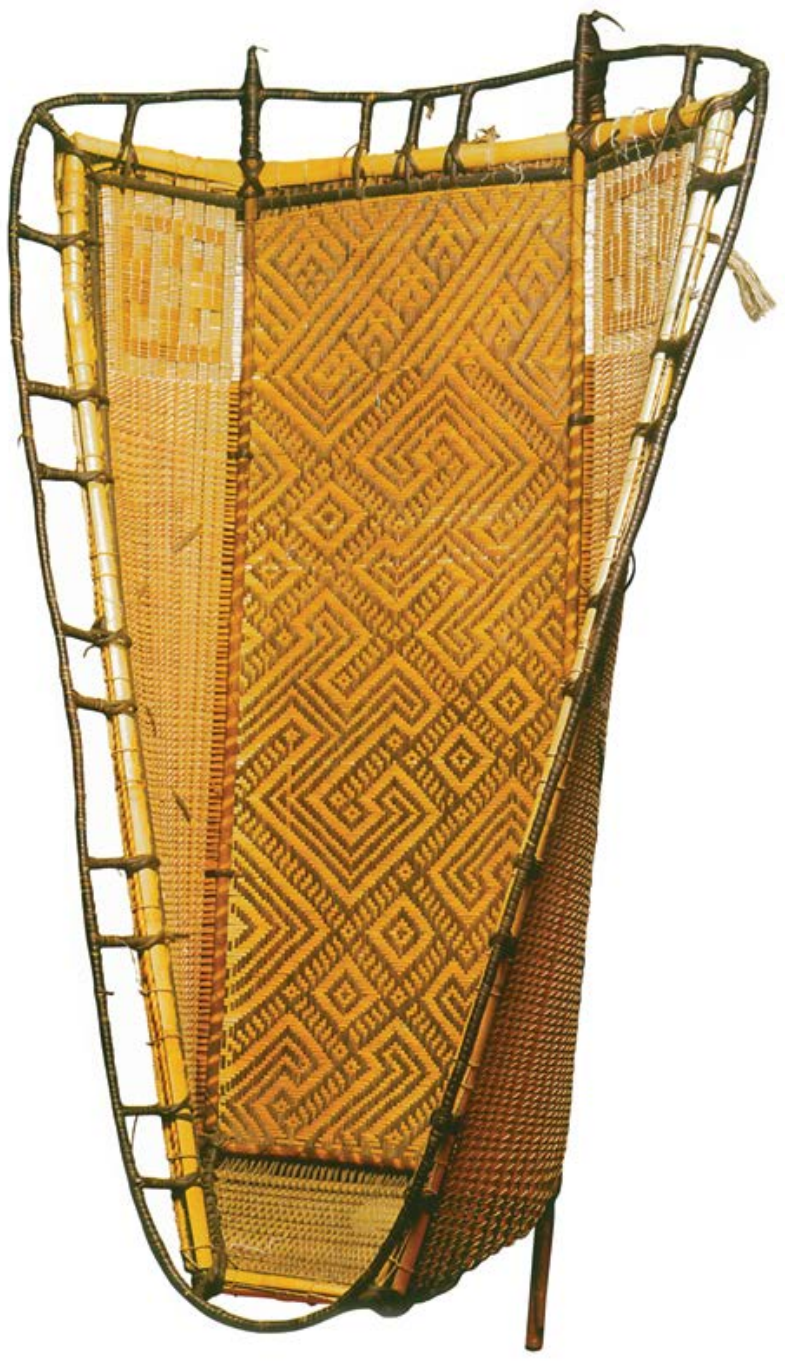


Conhecer as pinturas corporais próprias a outros coletivos é, portanto, conhecer a aparência específica que oferecem os outros aos seus próprios parentes, conhecer, em suma, sua face oculta. Assim, esse tipo de saber forma um componente essencial da "ciência" indígena. Além disso, portar os motivos de certa espécie permite identificar-se com essa sociedade específica, e de assinalar o seu não pertencimento, em um contexto e por um dado momento, a seu próprio coletivo. Se as mulheres achuar (um dos subgrupos do conjunto jivaro) pintam certos motivos no rosto quando vão trabalhar na roça é para se assimilar às populações vegetais com as quais interagem e aparecer-lhes sob um aspecto familiar. Essa lógica encontra-se também em contextos rituais, quando se trata de fazer vir os espíritos (ou de figurá-los) para interagir com eles. Pintando-se, ornamentando-se, ou vestindo máscaras em função de certo modelo de aparência, o grupo que realiza o ritual diz essencialmente aos espíritos: "vejam, não somos estrangeiros para vocês, outros; usamos as suas roupas, somos portanto seus parentes".

Entretanto, a pintura corporal não remete sempre ao mundo da sociabilidade e da proximidade parental. Ela pode também, inclusive por omissão, sintetizar outras condições relacionais. A falta de pintura é tão expressiva quanto a presença de motivos elaborados, na medida em que ela indica um estado de "invisibilidade cosmológica". Esse estado pode ser buscado quando uma pessoa se sente ameaçada por tentativas de afiliação emanadas de um coletivo inimigo - por exemplo, em caso de doença. Nessa situação, ela percebe o olhar de outros sobre si , outros que ameaçam fazê-la deslocar-se para uma posição de presa. Ela tenta então tornar-se invisível abstendo-se de ostentar sua roupa de espécie para que não possa ser reconhecida nem categorizada. A invisibilidade garantida pela nudez da pele equivale a uma condição voluntária de isolamento social, eventualmente reforçado pela reclusão em um espaço separado do universo doméstico do parentesco (fig. 21). Uma outra maneira de tornar(-se) invisível é cobrir inteiramente o corpo com uma camada de pintura negra. A cor faz papel de tela, escondendo o corpo que reveste e tornando-o indetectável aos Inimigos.

A outra modalidade de aparência à qual se opõem as pinturas que indicam um estado de sujeito ou de parente é aquela associada às pinturas de guerra. Esses motivos se distinguem dos "desenhos de humanos" por uma cor diferente - por exemplo, o negro em contraste com o vermelho ou com o dicromático - e por um traço distinto. A pintura de guerra assinala uma corporeidade não humana, integralmente predadora, tanto aos olhos das vítimas perseguidas quanto aos dos parentes dos guerreiros. 


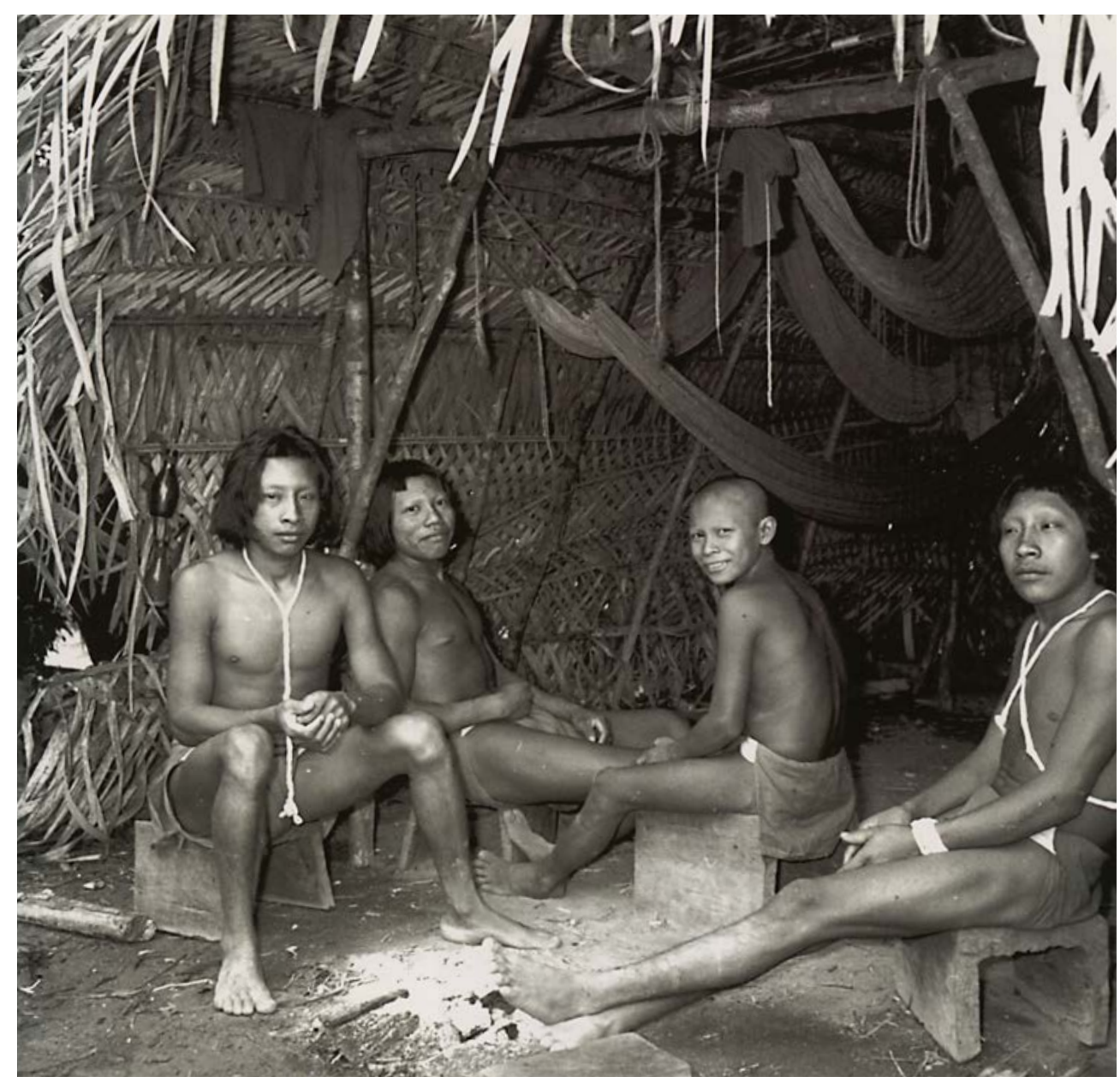

\section{CORPO DE PREDADOR}

\section{O esquema da predação: ver e comer}

Inscrita em um esquema de relações entre os seres segundo o qual toda entidade viva se alimenta de outras espécies, animais ou vegetais, e serve ela mesma de alimento a outras espécies, a relação constitutiva de identidade de um corpo não é neutra no plano qualitativo, e sua tonalidade afetiva não deve nada ao acaso. Todas as criaturas são habitadas por um desejo e uma capacidade de agressão em face de outras criaturas consumíveis. Esse apetite vital inerente a todos os seres animados é o modelo da intencionalidade atribuída no processo de subjetivação, sem dúvida porque ele sintetiza de maneira imediata ao mesmo tempo o desejo - a tensão em direção ao ter - e o juízo - a categorização de uma coisa, sua identificação enquanto elemento do mundo: a forma primeira do "ser-no-mundo" de um sujeito é uma relação de apreensão - em todos os sentidos do termo - de outrem.

Essa visão predadora das relações entre os seres justifica a importância que o pensamento indígena confere à questão do regime alimentar. É ele que constitui barraca de reclusão (1965). Foto de Jean-Marcel Hurault. "Os corpos destes jovens indígenas reclusos não estão pintados, de modo que eles não se tornem visíveis ao outro". 
um dos principais critérios de classificação dos seres animados; ele mede o grau de identidade e de diferença entre duas espécies ou dois exemplares de uma espécie. Ou, para dizê-lo ao contrário: comensalidade equivale a comunidade, e esta equivale a identidade. Daí o peso atribuído aos gestos de oferenda - ou de recusa-de alimentos, especialmente entre casais e entre pais e filhos. Daí também a força e a multiplicidade das restrições e prescrições alimentares observadas pelos indígenas de toda a Amazônia. Modificar seu regime é marcar tanto um movimento de afiliação e de identificação a uma outra classe de seres cuja alimentação costumeira se distingue daquela dos humanos, quanto, ao contrário, um movimento de desafiliação e de diferenciação em relação a uma espécie cujo regime seria anti-humano (fig. 22). Assim, os guerreiros homicidas são submetidos longamente a um regime draconiano que visa a afastá-los do gosto pela carne de "caça" humana que lhes é atribuído. Suspeitamos que o canibalismo de guerra praticado outrora por numerosas sociedades amazônicas se inscreve na mesma lógica. Tratando o corpo de um humano inimigo como carne de caça, o canibal se lança a uma dupla operação: por um lado, ele se associa a um predador supremo, por exemplo, a um dos espíritos imortais que se alimentam justamente de humanos; por outro lado, ele marca uma distância ontológica - a não identidade - entre ele (e o coletivo ao qual ele pertence) e o inimigo (e o coletivo ao qual este pertence).

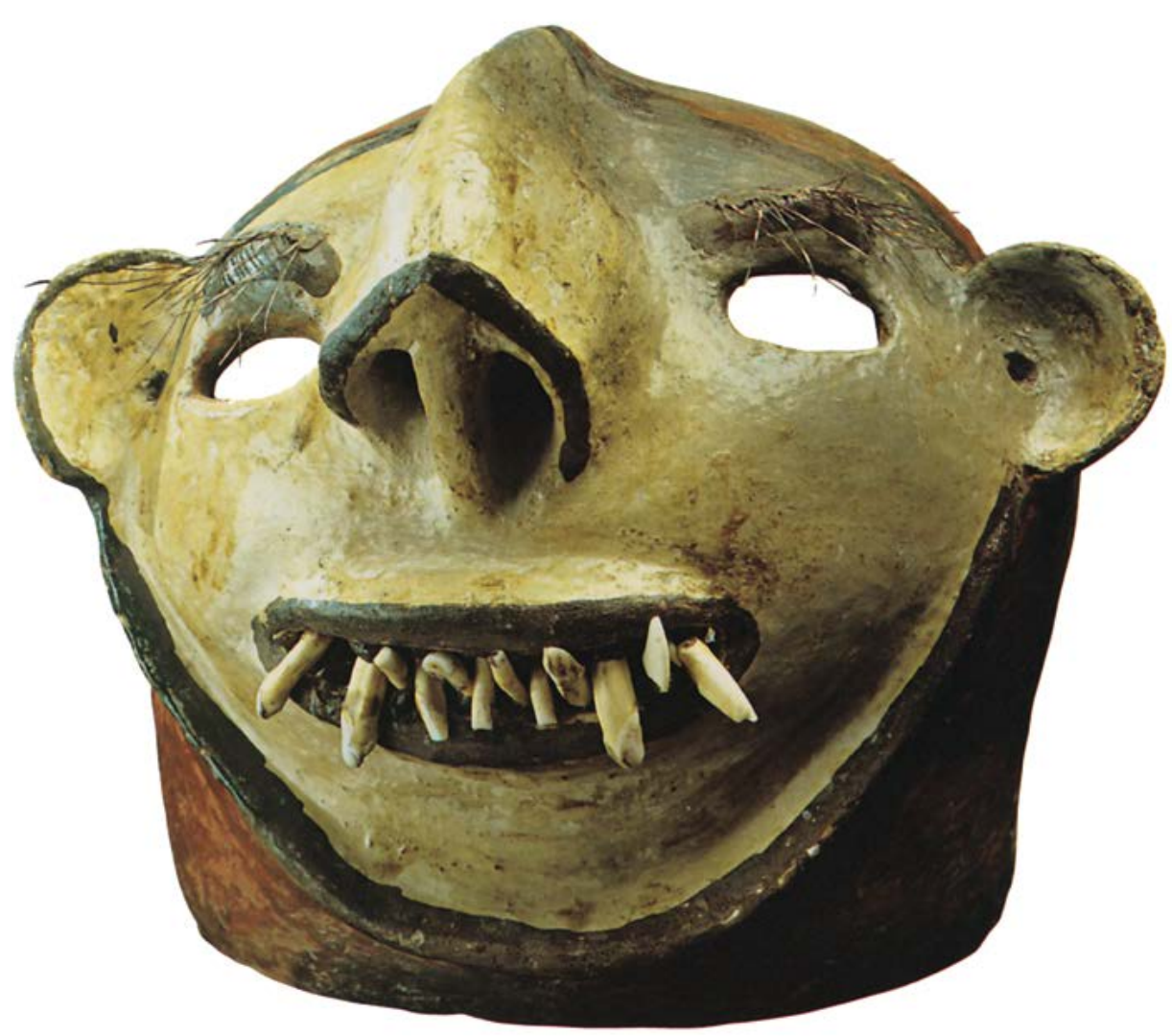

Figura 22 Cabeça em cerâmica, população piro.

A. $28 \mathrm{~cm}$. Inv. IVc16946. Acervo Museum Der Kulturen (Bâle). "É o retrato de um 'predador' provido de dentes, de um olhar, um rosto humano, e elementos de corporeidade animal." 
O esquema da predação imprime também sua marca sobre as relações entre homens e mulheres, de duas formas distintas. Por um lado, a comunidade de regime alimentar faz com que a diferença entre os sexos seja minimizada em relação àquela entre humanos e não humanos, sendo a heterogeneidade de regime o principal critério de discriminação entre essas duas categorias. Por outro lado, a diferença anatômica e sobretudo comportamental entre homens e mulheres - primodialmente, o fato de que são as mulheres e apenas elas que carregam e dão à luz aos membros da espécie - predispõe a considerar o conjunto dos homens e o conjunto das mulheres como coletivos distintos, pelo menos como subespécies diferentes (os índios falantes do espanhol costumam mesmo utilizar o termo "raça" para designar cada um dos dois sexos). Essa divergência, quando combinada com a diferença atribuída em princípio aos parentes por casamento ou afins - em outras palavras, quando se trata de pessoas desposáveis —, resulta em comportamentos "predadores" estilizados. Assim, o casamento amazônico, lá onde ele é ritualmente marcado, se enquadra de maneira mais ou menos literal no esquema da captura ou rapto de uma mulher de um grupo inimigo, mesmo quando se trata de uma parenta próxima. É que uma mulher "consumível" no plano sexual deve ser "outra", ou a união com ela seria incestuosa; mas, a partir do momento que essa mulher é definida como diferente de si, as relações com ela tendem a ser subsumidas pelo esquema da predação; e assim a presença desses elementos de comportamento de caçador ou guerreiro marca o início da coabitação conjugal.

O pensamento indígena não confere quase nenhum lugar à noção de gênero no sentido de "sexo cultural". Em função dos contextos e das esferas de sociabilidade em jogo, a diferença entre homens e mulheres é ora dissolvida em favor de uma diferença mais pesada no plano ontológico, aquela entre "nós" (os humanos) e "os outros" (os não humanos) - caso no qual a distância entre os dois sexos é anulada -, ora exagerada e exacerbada pela assimilação da relação homem-mulher a uma relação entre espécies distintas, tomada no sentido da complementaridade entre presa e predador. Isso explica porque as mulheres têm frequentemente um papel de primeiro plano nos rituais canibais ou guerreiros, em que elas são encarregadas de encarnar os Inimigos e falar por eles ou, ao contrário, de tomar o lugar dos homens ao dar corpo ao "Nós" - de ambos os sexos - enquanto os homens ocupam a posição de Outros - às vezes inclusive parodiando as mulheres. Em suma, homens e mulheres são ora demasiado semelhantes, ora demasiado diferentes para constituírem cada qual um "gênero". Eles não podem formar, um face ao outro, ou variedades da mesma espécie, ou espécies distintas. Cabe sublinhar também que o papel determinante desempenhado pelo esquema da predação na conceitualização indígena das relações entre os seres não implica que estas tomem sempre e necessariamente a forma 
da agressão devoradora. A incorporação de outrem constitui certamente o pano de fundo do mundo dos viventes, a tendência de base que governa suas relações. Entretanto, o "desejo do outro" pode afirmar-se em toda uma gama de relações afetivas, até atingir o extremo oposto da predação, a saber, a piedade. Esta é uma suspensão daquela animosidade canibal que faz de outrem uma carne consumível. A compaixão - afeto muito frequentemente evocado, sob nomes variados, no discurso amoroso ou nos enunciados dirigidos aos espíritos - traduz a percepção, às vezes involuntária, de uma identidade possível entre o sujeito e o outro. A piedade implica portanto também uma transformação na apreensão da forma do corpo do outro: em vez de ver sua caça com um corpo de animal, o caçador ou o guerreiro invadido pela compaixão toma subitamente consciência de estar diante de um corpo de humano.

\section{Em um corpo de jaguar}

Dotar-se de um corpo com capacidades de predação intensificadas, análogas a do jaguar, é um objetivo perseguido pelos homens em quase todas as sociedades amazônicas. Entretanto, essa busca de potência implica um distanciamento dos seus semelhantes e, por consequência, um abandono ao menos parcial do estado de humanidade. Essa condição é perigosa para os próximos, porque eles correm o risco de não serem mais reconhecidos como congêneres. E ela é em si mesma difícil de suportar, pois está associada por princípio à solidão. Ao mesmo tempo, o regime corporal do jaguar fascina porque ele ilustra uma condição suprema de autonomia e individuação. Em razão de sua energia predadora, o grande felino é a imagem mesma da potência de ser.

Colocar-se em situação de predador permite situar-se em face do outro em uma relação de objetivação: em lugar de perceber o outro sob o ângulo de sua subjetividade, o predador vê o outro apenas como animal de caça, carne desprovida de uma subjetividade que poderia Ihe dizer respeito. Essa atitude é aquela que os índios emprestam aos predadores em relação às espécies das quais se alimentam. Entretanto, mesmo que pratiquem cotidianamente a caça e valorizem ao extremo essa prática, os amazônicos não consideram que seus animais de caça são "naturalmente" desprovidos de subjetividade, nem que a morte de animais com fins de consumo seja uma ação banal e sem consequências para aquele que a realiza. Ao mesmo tempo que se alimentam deles, os amazônicos tratam os animais de caça como pessoas. A maioria dos animais de caça é sujeito por excelência para certos índios, como os Wari, que consideram que apenas os animais dotados de uma "alma" são dignos de serem mortos e consumidos. Na maioria dos casos, os animais caçados são, portanto, tratados como sujeito até o instante em que são mortos. Enquanto o caçador rastreia sua caça, ele fala 
com ela como falaria com um humano, dirigindo a ela encantações silenciosas destinadas a influenciá-la e aprisioná-la; ele procura atraí-la pela sedução, como faria com uma mulher. Ademais, o tratamento respeitoso reservado à carcaça do animal morto mostra bem que a subjetividade do bicho vivo permanece presente. Assim, seu cadáver é submetido a diversos procedimentos visando a separá-lo da "pessoa" que o habitava e a remeter sua "alma" ou sua imagem ao seu coletivo de origem. Essa operação permite transformar seu corpo em carne, para que ele possa ser consumido sem perigo.

A objetivação ligada à morte de um animal na caça é, portanto, fortemente atenuada pela relação de sedução ou de respeito manifestada na subjetivação dos comportamentos do animal que se persegue. De modo paradoxal, enquanto o abate dos animais de caça é "eufemizado", a guerra contra humanos não o é de maneira nenhuma. Assimilada a uma agressão animal, a ação guerreira é, ao contrário, celebrada, cantada, arremedada, ritualizada, e seus aspectos sanguinários são valorizados. De fato, a guerra é identificada a uma forma de caça com fins de consumo tal qual ela é praticada, não pelos (verdadeiros) humanos, mas pelos animais, mais precisamente pelos grandes carnívoros, como o jaguar, a águia ou o urubu. Se na caça o "predador" (humano) trata sua presa de maneira bem humana e deve se forçar para animalizar sua vítima, na guerra se produz exatamente o inverso: o guerreiro perde sua humanidade e se transforma em animal. Eis o que exprimia com concisão a proposição do chefe tupinambá Cunhambebe, registrada no século XVI, ao afirmar para Hans Staden seu gosto por carne humana: "Sou um jaguar. E está gostoso".

A predileção dos índios por ornamentos feitos com "armas" extraídas dos corpos de animais, sobretudo os dentes e as garras (fig. 23), remete à mesma ideia: ornando-se de signos de uma aptidão carnívora, os índios demonstram e ressaltam sua própria disposição a tornarem-se "jaguarescos" - disposição indissociável da vontade de produzir o parentesco e de fazer corpos con-

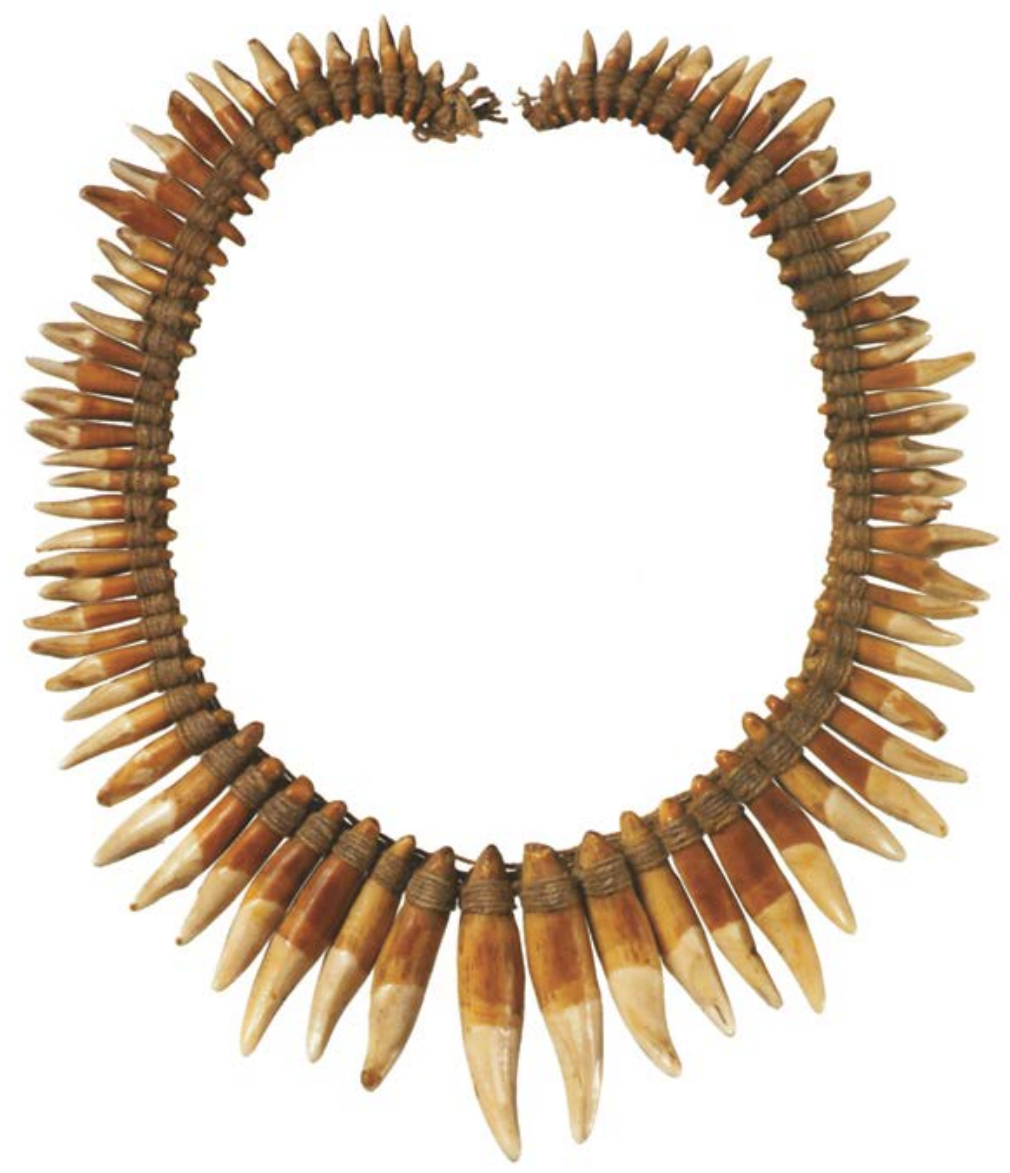


gêneres. Nos rituais associados à guerra, a assimilação dos guerreiros - e em particular dos homens responsáveis por mortes - a grandes predadores animais é constante e por isso, entre outras razões, o homicídio é frequentemente concebido como um ato de devoração. O matador é geralmente submetido, após seu feito, a toda uma série de proibições alimentares visando a lhe desabituar de seu gosto por carne crua e a lhe reacostumar a um regime alimentar humano. Do mesmo modo, a aplicação sobre o corpo do guerreiro de pinturas corporais distintas daquelas que exprimem e refletem a condição de humanidade visam a dotá-lo de atributos de animalidade - ou, em todo caso, de não humanidade. A identificação a propriedades corporais animais, assinalada por seus emblemas de disposições predadoras (os ornamentos de garras e dentes), é aqui radicalizada até formar uma corporeidade integralmente predadora. Antes que disfarce de humano em jaguar, a pintura corporal de guerra é uma roupa de espíritojaguar, a vestimenta de uma entidade que reunirá, à maneira de uma essência, todas as qualidades predadoras do animal e apenas estas ${ }^{13}$.

A assimilação do guerreiro a um carniceiro devorador de carne humana confere à guerra amazônica um forte aroma de canibalismo, mesmo nas áreas culturais em que nunca foram registrados vestígios de práticas antropofágicas. Isso posto, os canibais amazônicos incontestes - tais como os Tupinambá do século XVI - ficariam horrorizados pela acusação de comerem seus semelhantes. Na verdade, o canibalismo indígena afirmava justamente uma diferença radical entre o matador e sua vítima. Eles projetavam ambos para fora da sua comunidade humana: o matador em direção a uma identidade de predador animal ou divino, a vítima (ao menos seu corpo) em direção a de um animal de caça. Falar de antropofagia nesse caso é portanto, a rigor, um contrassenso: o que é comido é certamente humano, mas como o canibal, ele mesmo, não é humano, o que ele consome é diferente dele, ou seja, é carne que se come, como a carne de caça (fig. 24).

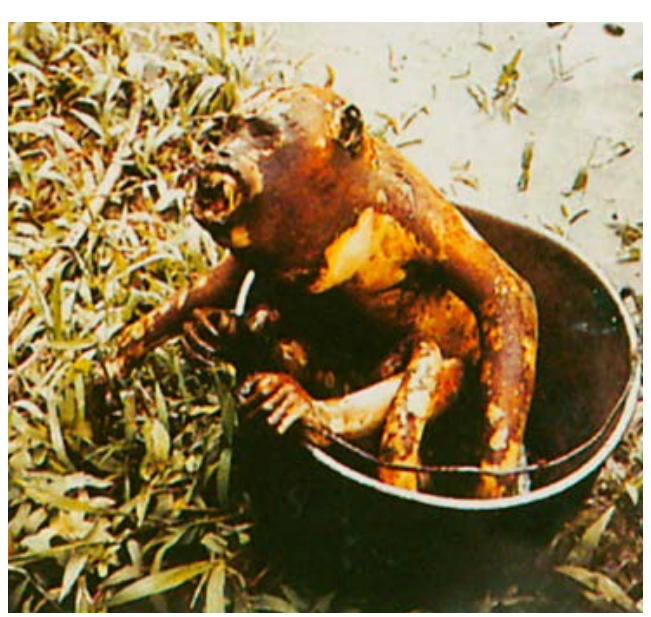

Figura 24

Macaco cozido, prato muito apreciado e quase humano. Foto de Philippe Erikson. "Eu sou um jaguar, e está gostoso' disse em 1557 o chefe tupinambá Cunhambebe a Hans Staden, seu cativo, por ocasião de um festim canibal". 


\section{Devir inimigo}

O consumo (real ou imaginário) de uma vítima de guerra relaciona-se, entretanto, a apenas um aspecto da pessoa do inimigo. Outros aspectos, inerentes à sua qualidade de sujeito, são destacados de seu corpo-objeto para formar novas entidades antropomorfizadas, que podem ser adotadas, familiarizadas, ou ser o objeto de uma gestação no corpo do matador. Esses elementos de personitude associados ao corpo de um indivíduo cuja identidade "inimiga" acaba de ser abolida terminam, portanto, por ser integrados ao coletivo dos matadores, sob a forma de uma pessoa virtual suplementar ou sob a forma de uma capacidade de procriação intensificada, promessa de um futuro aumento do coletivo.

Frequentemente, esses elementos de subjetividade oriundos do inimigo são figurados em troféus. Assim, as cabeças reduzidas jivaro remetem, por seu tamanho, ao bebê que o inimigo assassinado se tornará ou engendrará; mas elas encarnam também, de maneira simultânea, outras posições estruturais, especialmente a de Inimigo e a de Parente consanguíneo, uma e outra igualmente abstratas (fig. 26). O inimigo humano recebe, assim, um tratamento análogo àquele aplicado a um animal de caça: sua subjetividade portadora de identidade e seu corpo porta-

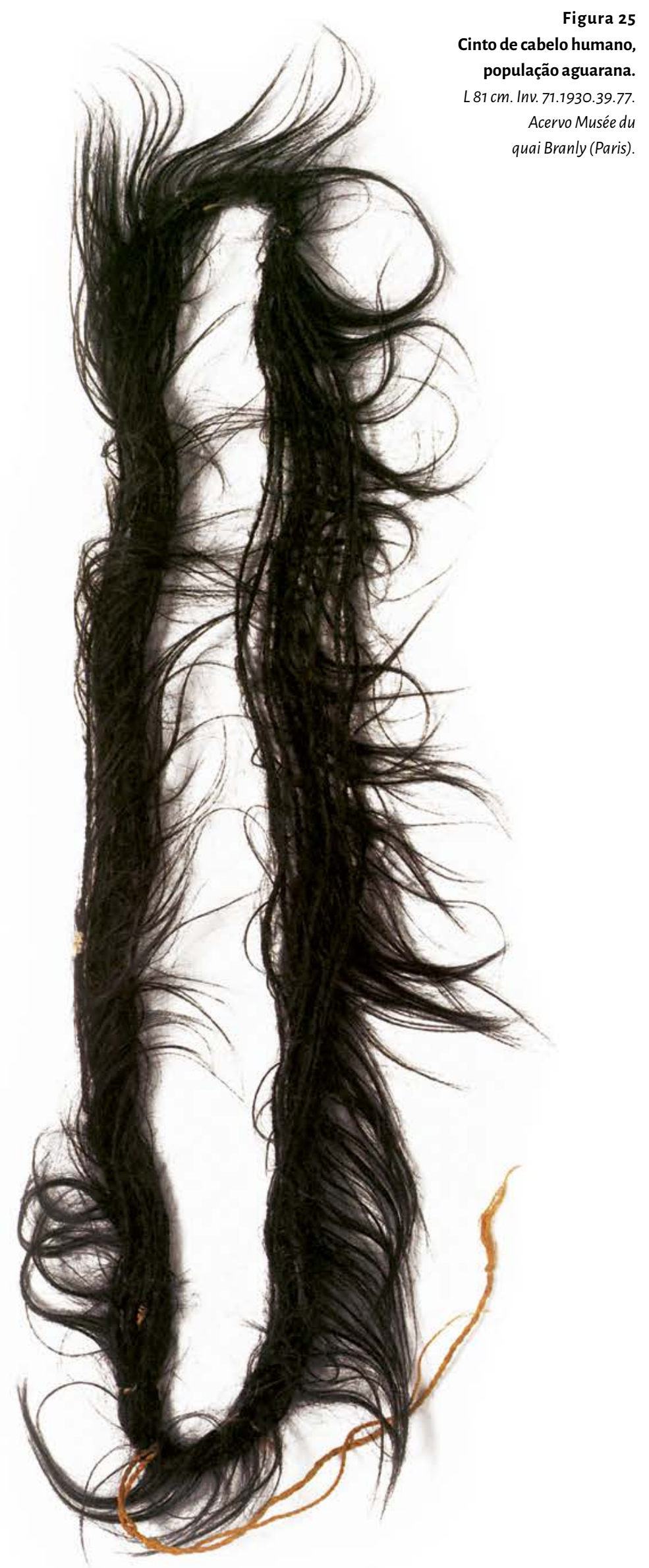


dor de alteridade são dissociados, para que a primeira se vincule a uma nova silhueta de congênere e o segundo se transforme em objeto de consumo.

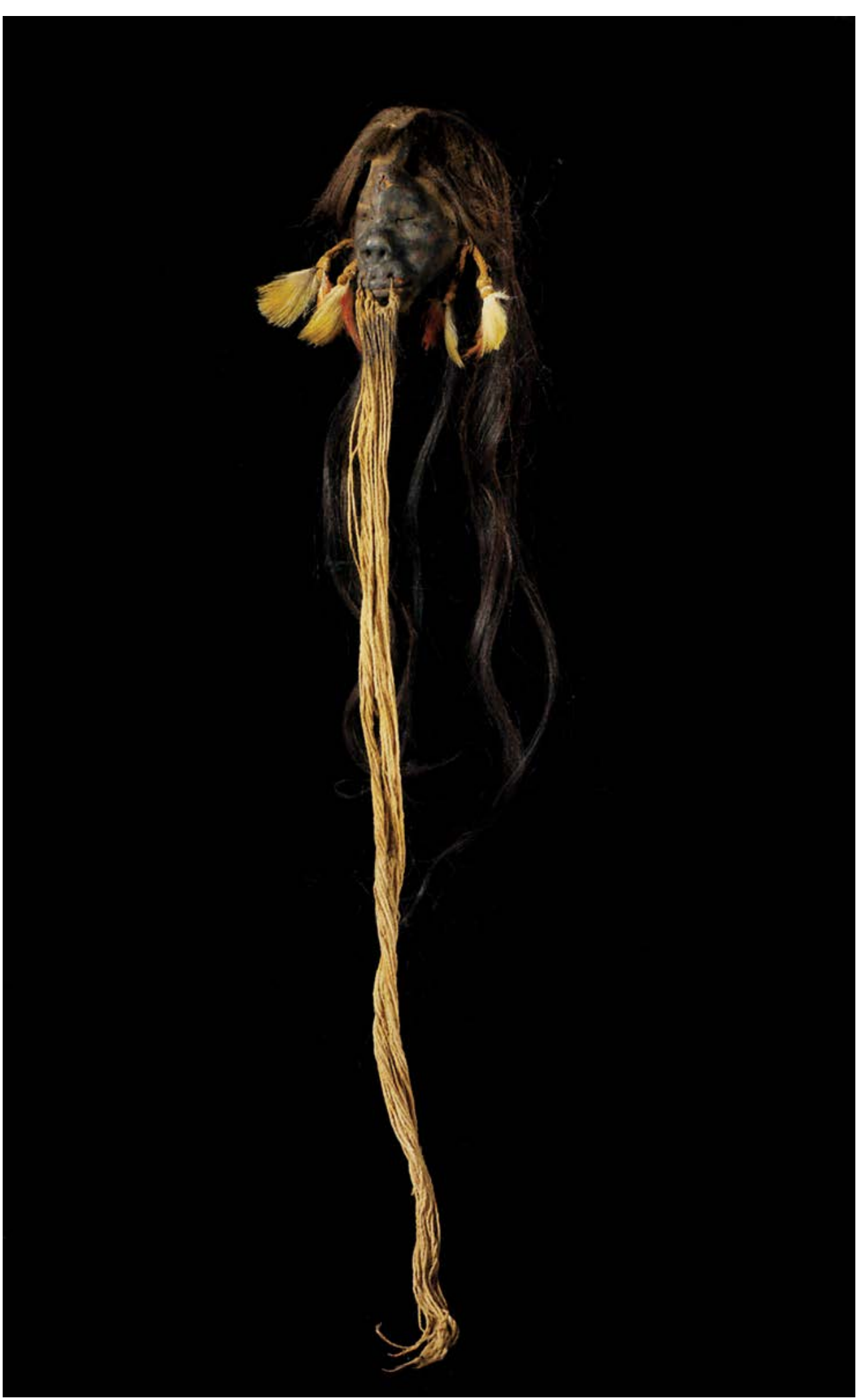

\section{Figura 26}

Cabeça humana reduzida, população jivaro.

A $70 \mathrm{~cm}$. Inv. 71.1880.7.170 Acervo Musée du quai Branly (Paris).

"Cindida no seu perfil, ela apresenta um rosto que pertence a dois sujeitos virtuais: um inimigo e um parente, um homem e uma mulher, um consanguíneo e um afim, um morto e um embrião, todos convocados ao tempo de um ritual". 
O porte ostentatório, notadamente em contexto ritual, de ornamentos fabricados com restos humanos - dentes, cabelos, peles, ossos diversos (fig. 25) ${ }^{14}$ - obedece a uma lógica similar (mas inversa) àquela que preside a exibição de elementos de corporeidade animal. Do mesmo modo que os humanos assinalam, pelo uso de garras e de dentes animais, disposições predadoras, corolário da capacidade de fabricar corpos de parentes, ao vestir-se de pedaços de corpos de humano o guerreiro manifesta sua capacidade de assumir uma corporeidade não humana, e portanto - e sobretudo -, a perspectiva inerente a essa forma de corporeidade. O porte desse gênero de ornamento significa: "Atenção, sob minha aparência de humano há um corpo (e um olhar) de jaguar pronto para o salto ". A corporeidade ambígua do guerreiro se combina com uma perspectiva igualmente equívoca: embora congênere, o guerreiro dedicado ao homicídio está sempre em risco de ver os corpos de seus semelhantes como se animais de caça, ou, o que dá na mesma, de tomar subitamente seus próprios parentes como inimigos e tratá-los como tal por consequência. A fascinação pelo "ponto de vista do inimigo" se exprime de modo espetacular em numerosos rituais amazônicos organizados em torno da perspectiva do predador de humanos. As máscaras tapirapé, chamadas cara grande ou ype, por exemplo, figuram a alma de um inimigo kayapó abatido durante um enfrentamento armado (fig. 27). O "ator" que porta a máscara é o protagonista da cerimônia, e é a partir de seu ponto de vista que toda a ação ritual se desdobra. Uma função similar é atribuída à máscara kayapó em cera coroada com um diadema (fig. 28) ou, ainda, aos crânios decorados munduruku. Esses artefatos macabros não figuram unicamente, $\mathrm{e}$ nem de maneira privilegiada, o inimigo singular abatido durante um ataque específico; são, antes, como coringas do baralho, chamados a encarnar ao longo de um ciclo ritual diferentes formas de uma identidade estrutural - aquela do Outro ou do Inimigo - e as perspectivas que essa identidade assume. Os ritos que se efetuam em torno desses "objetos-sujeitos" operam uma inversão progressiva da relação que une o matador a sua vítima - ao menos à parte desta que não foi transformada em carne da caça -, de tal modo que o matador termina por tomar o lugar da vítima. Esta, por sua vez, transformada em assassina de seu matador, narra - frequentemente pela voz das mulheres que participam do ritual - seus feitos de guerra, como ela exterminou os homens do grupo de vencedores, como ela seduziu e fecundou suas mulheres. Em suma, tudo se passa como se fossem os inimigos que efetuassem o ritual e não aqueles que efetivamente os venceram (fig. 29). Essa configuração se torna menos estranha se imaginamos que, na relação de homicídio, a vítima ocupa o polo do humano e o matador, aquele do animal; ora, produzir um contexto ritual é uma atividade de humanos. O objetivo das práticas rituais que o matador observa ao longo de meses após o homicídio é, justamente, o de retornar a sua posição humana inicial.

14 [Nota da Tradução] O texto original também faz menção nesse ponto à figura "Tapa-sexo feminino com dentes humanos, população yagua. L $32 \mathrm{~cm}$. Inv. 3335" presente no acervo do Museo Nazionale Preistorico Etnografico Luigi Pigorini, em Roma. Não foi fornecida autorização para publicação dessa imagem, de modo que remetemos o leitor ao texto original para acesso a ela. A legenda da imagem no texto original dizia: "O barulho deste antigo ornamento, produzido ao longo do ritual, é evocado nos cantos e nas narrativas associados à guerra". 


\section{Rostos do inumano}

Essa desconcertante inversão de papéis nos rituais guerreiros amazônicos se explica sem dúvida pela objetivação do corpo social produzida pela perspectiva de um outro sobre si-de um outro diferente de si. A objetivação é uma condição para fundar as identidades tanto coletivas quanto individuais, mas isso não é possível senão pelo recurso ao ponto de vista de um outro. Ora, no mundo amazônico, o outro está inserido no esquema da predação. Já que ele é por definiç̧ão diferente do sujeito, a relação com ele necessariamente será de presa ou de predador. Esse ponto de vista do outro de que o Eu precisa para experimentar-se como tal é, portanto, representado como uma perspectiva de predador sobre o Eu, quer dizer, sobre o humano. Entende-se assim por que, nessas condições, a imensa maioria das máscaras amazônicas é provida de bocas com dentes. A função das máscaras é a de representar não humanos: sejam eles inimigos, animais ou entidades sobrenaturais, são sempre espíritos - imagens - que são figurados. Esses últimos são necessariamente predadores de humanos, mesmo aqueles que têm um valor positivo, e que se poderia mesmo chamar de deuses (por exemplo, esses Imortais que se tornam os mortos araweté). Os espíritos são aqueles não humanos que ocupam, na maioria das vezes, uma posição superior à

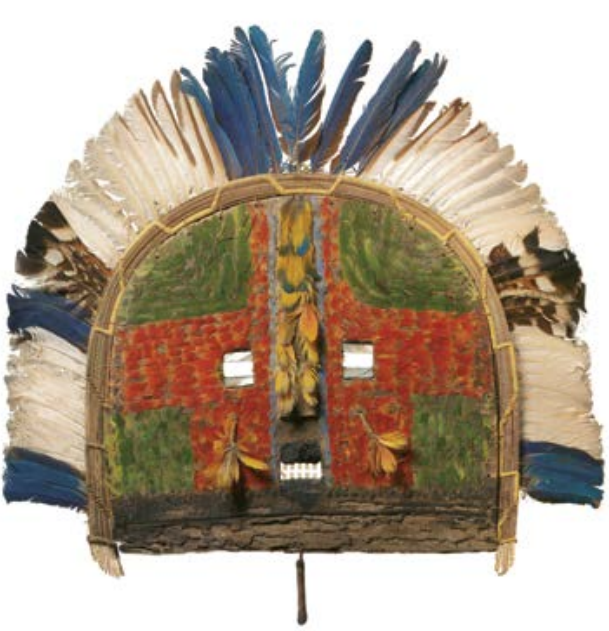

Figura 27

Máscara cara grande ou ype, população tapirapé.

A. $80 \mathrm{~cm}$. Inv. 70.2003.2.4. Acervo Musée du quai Branly (Paris)

"Vestida com um longo adorno de cabeça e uma capa de fibras, esta máscara figura o espírito de um guerreiro inimigo assassinado, que é convocado ao longo de rituais destinados a favorecer a caça e durante os quais é evocado um combate vitorioso entre os Tapirapé e seus inimigos Kayapó ou Karajá".

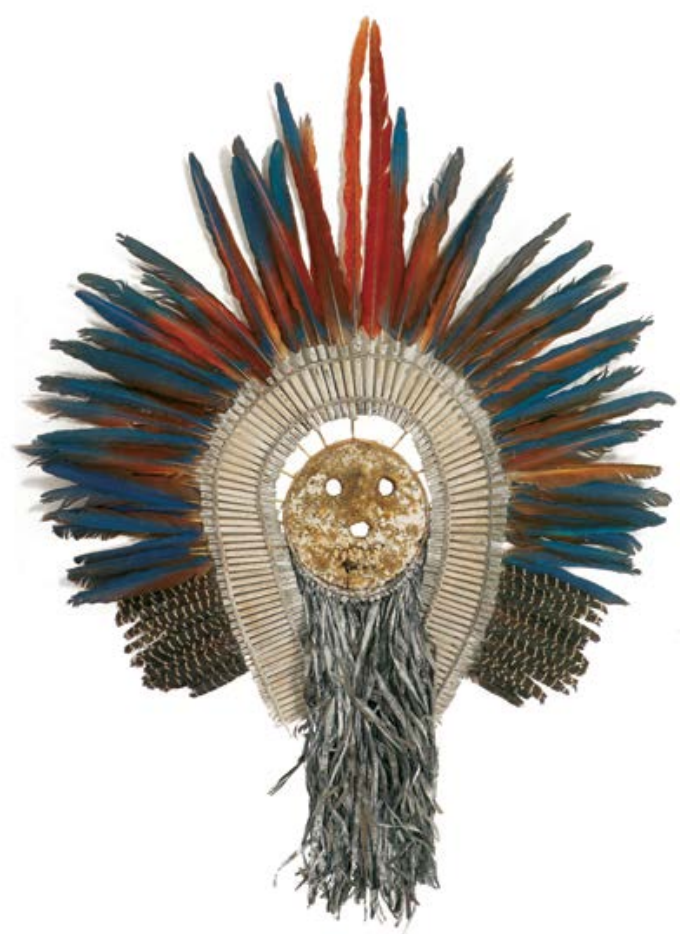

Figura 28

Máscara em cera coroada com um diadema de penas de arara, população kayapó.

A. $156 \mathrm{~cm}$. Inv. 70.2003.2.6. Acervo Musée du quai Branly (Paris).

"Ela representa sem dúvida um espírito de inimigo, como a máscara ype tapirapé. Trata-se talvez de uma criação isolada, inspirada no exemplo de um grupo vizinho".

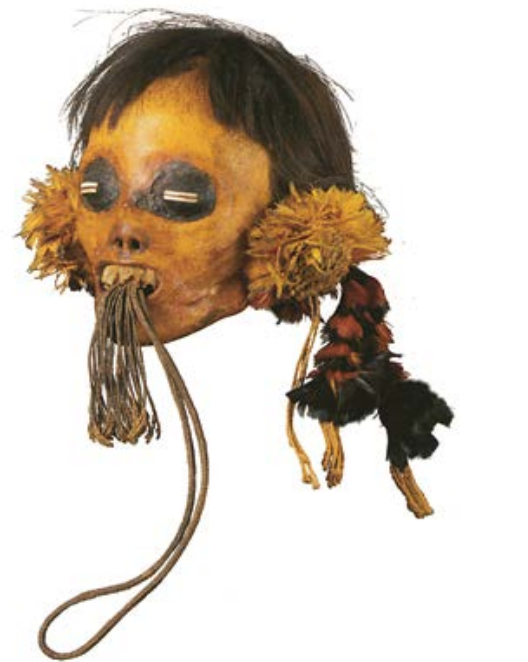

Figura 29

Cabeça mumificada representando um inimigo transformado em congênere, população munduruku. A $30 \mathrm{~cm}$. Inv. 71.1950 .87 .1 Acervo Musée du quai Branly (Paris) "Independente do sexo da vítima, a cabeça é considerada como masculina. O matador acompanha os caçadores com seu troféu, transformado em 'mãe dos queixadas' para atingir a caça”. 
dos humanos, na escala dos existentes animados de intencionalidade predadora. Isso basta para torná-los "canibais", comedores de homens, um traço invariavelmente representado nas figurações dos espíritos, a tal ponto que seu retrato pode, em alguns casos, se reduzir ao esboço de um rosto envolvendo um buraco com dentes. Mas os traços formais das máscaras amazônicas remetem em geral a muitos outros aspectos do corpo dos espíritos. A maior parte dessas máscaras pertence a conjuntos, formando "famílias". Isso indica que os espíritos são populações, ou em outras palavras, espécies. Além disso, as máscaras não reproduzem o corpo dos espíritos; elas representam, antes, suas "roupas", ou seja, seus adornos, pinturas e ornamentos: são, em suma, máscaras de máscaras (figs. 31 a 33). Muito frequentemente, elas são amarradas a túnicas de entrecasca ou a longas saias de fibras vegetais. Esses apêndices servem tanto para esconder o corpo da pessoa humana que veste a máscara, emprestando sua intencionalidade ao corpo de espírito, quanto para figurar o caráter amorfo desse corpo estranho do outro, isto é, sua aparência ao mesmo tempo indefinida, não humana e antropomorfa (fig. 30).

O caráter ameaçador dos espíritos não significa que seja impossível aos humanos desenvolver com eles relações não predadoras. Pelo contrário, a maioria das sociedades amazônicas inclui em seu efetivo grandes

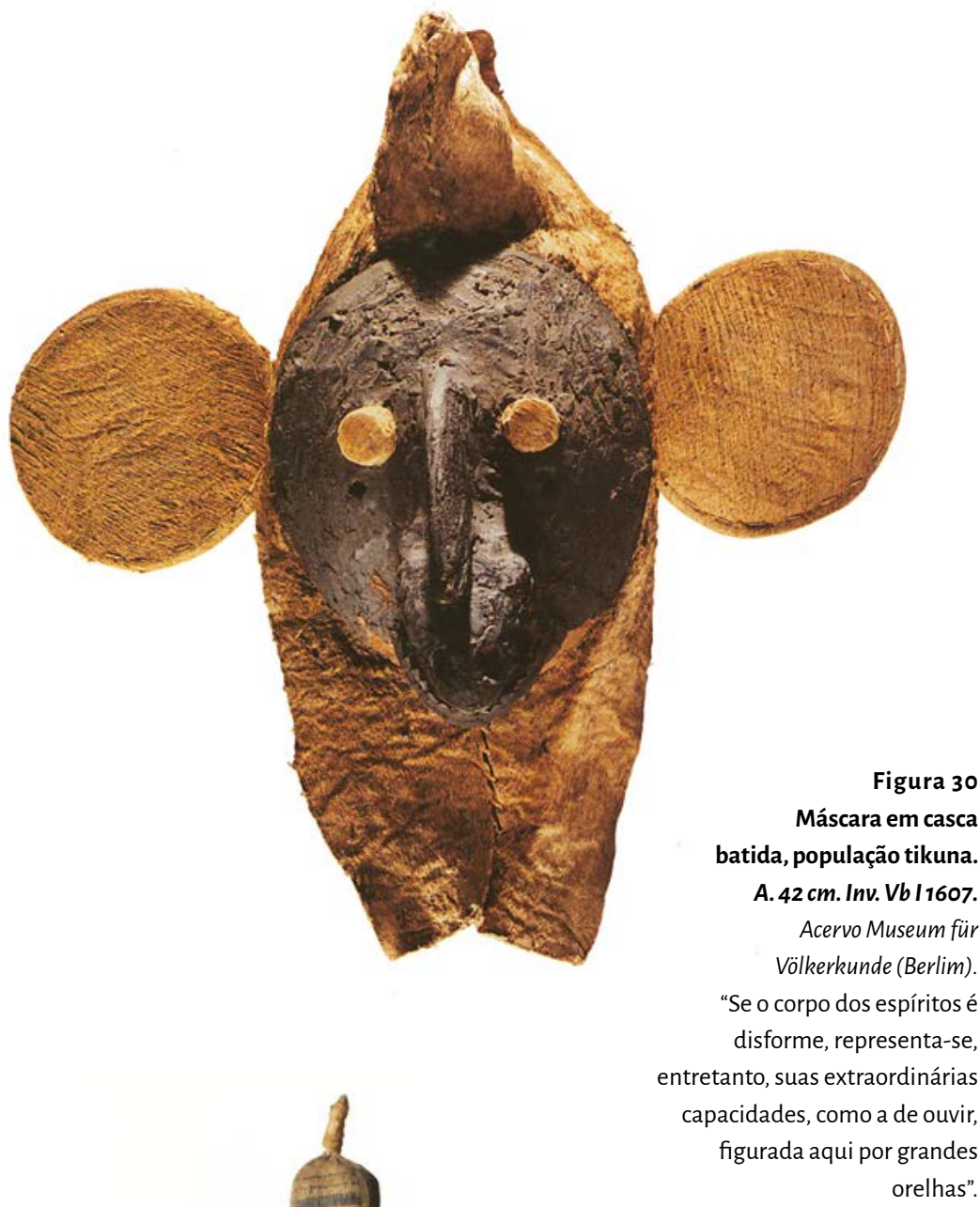

Figura 31

Máscara, vestimenta do jurupari, região do rio Madeira. A. $140 \mathrm{~cm}$. Inv. 71.1904.4.1. Acervo Musée du quai Branly (Paris). 
populações de espíritos que coabitam pacificamente com os viventes, mantendo relações de parentesco com estes. Todavia, essas relações amistosas supõem uma aproximação ontológica entre humanos e não humanos, uma "familiarização" que toma frequentemente a forma de um amansamento, seja do espírito pelo humano (o exemplo mais conhecido é aquele dos espíritos auxiliares dos xamãs), seja do humano pelos espíritos, sejam-e este é de fato o caso mais frequente - ambas as coisas ao mesmo tempo. Esses exercícios de socialização recíproca são feitos em rituais dos quais as mulheres são frequentemente excluídas. Às vezes, trata-se simplesmente de fazer vir os espíritos para festejá-los, à maneira de um convite entre vizinhos, com a finalidade de estabelecer boas relações. Em outros casos, trata-se também e sobretudo de se identificar aos seres sobrenaturais vestindo suas roupas, assimiladas àquelas dos "corpos primigênios", próprios do tempo do mito. A experiência repetida dessa corporeidade extra-humana-e dos afetos inumanos que a animam, provado pela vontade manifesta dos seres mascarados de amedrontare maltratar as crianças - é frequentemente julgada necessária à formação de uma pessoa adulta. (fig. 34).

A capacidade de ligar, individual ou coletivamente, relações não predadoras com a alteridade - aptidão cuja forma mais elementar é a arte de amansar pequenos animais selva-

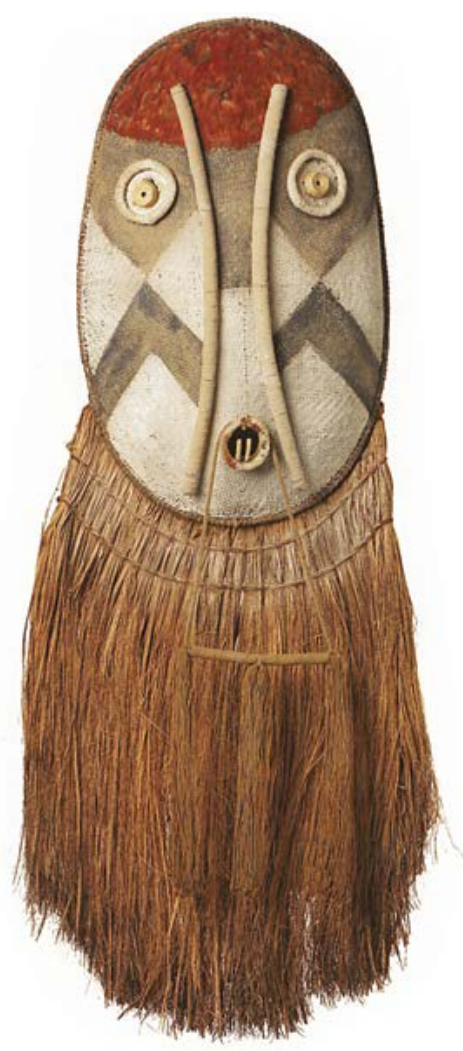

Figura 32

Máscara, população kamayurá, região do $X i n g u$. A $131 \mathrm{~cm}$. Inv. 70.2003.2.1. Acervo Musée du quai Branly (Paris) "Esta máscara representa aquelas que são usadas pelos espíritos enquanto eles ocupam a posição de humanos. Ela evoca igualmente, por sua forma e sua 'barba' de fibras, o caráter irrepresentável dos 'corpos' de não humanos".

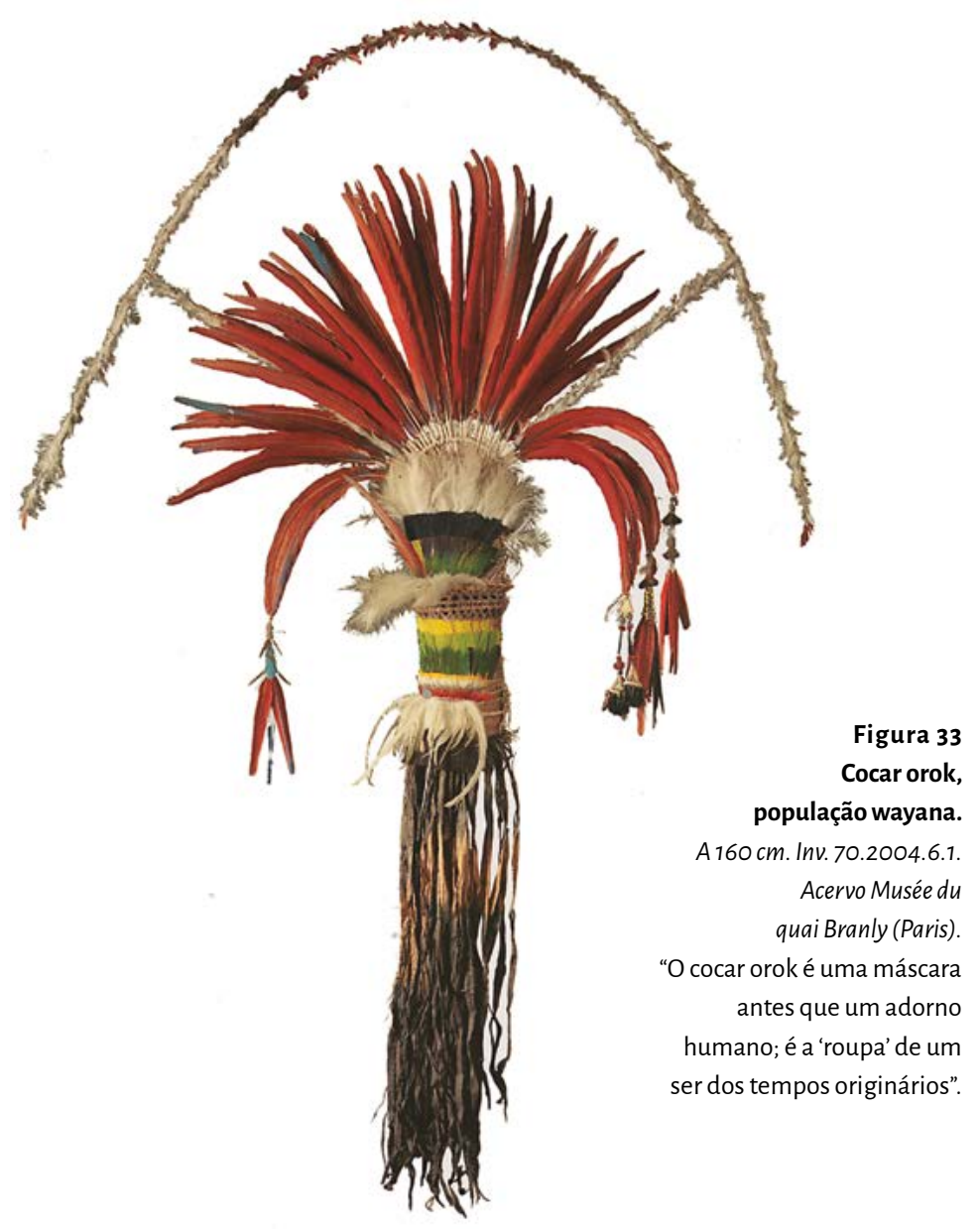


gens -é indispensável para se atingir o estatuto de pessoa completa, e isso não concerne apenas aos xamãs. O sucesso de um bom número de processos técnicos "profanos" - caça, pesca, produção de artefatos - depende das relações que um indivíduo logra consolidar com coletivos de espíritos, sem falar das relações, ao mesmo tempo de identificação e de enfrentamento, que um guerreiro amazônico deve desenvolver com espíritos "inimigos" para adquirir a potência necessária à realização de um homicídio. Em contrapartida, se a predação dos humanos pelos espíritos não é transformada em relação positiva pela familiarização e identificação recíproca, os primeiros correm forte risco de se ver na posição da caça: eles se tornam a presa de um predador mais forte que eles, que vê seu corpo sob a forma de um animal de caça.

\section{CORPO DE PRESA}

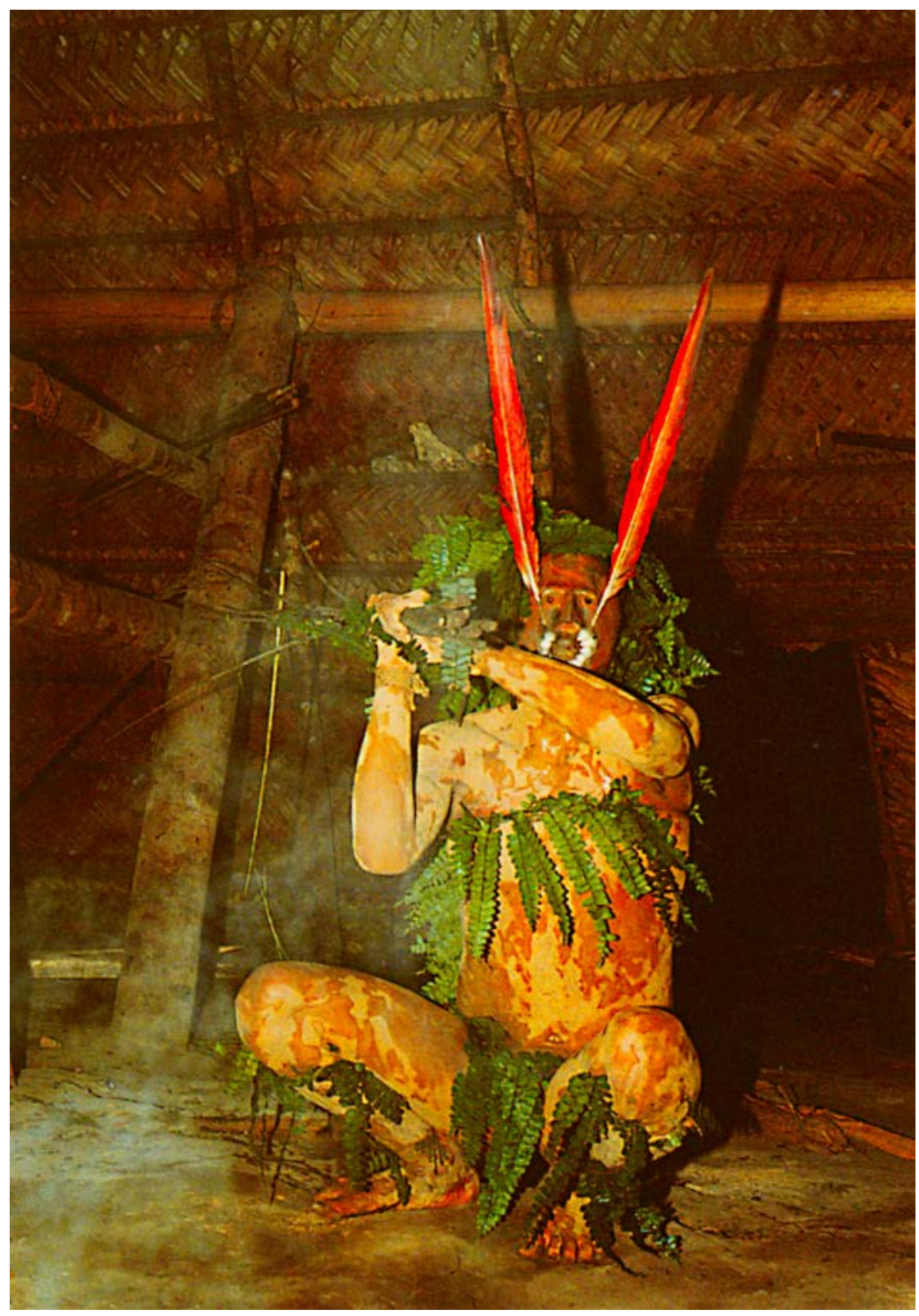

A posição de presa está logicamente associada à doença e à morte que resultam de uma agressão exercida de forma direta, por um inimigo em carne e osso, ou indireta, por espíritos que agem a mando de um xamã inimigo ou de um não humano - por exemplo, um espírito dono de um animal de caça. Os amazônicos assimilam a doença e a morte a um ato de devoração, prova suplementar, se ainda faltasse alguma, do papel desempenhado pelo esquema da predação. Assim, eles dizem correntemente de um morto ou de um moribundo que ele "foi comido", seja qual for a causa de sua agonia. De resto, os povos indígenas não costumam fazer uma distinção clara entre um assassinato ostensivo, uma morte causada por uma agressão xamânica e uma morte que qualificaríamos de natural. Em todos os casos, o falecimento ou o mal-estaré causado pela ação predadora do outro, seja um outro humano, uma dada variedade de espíritos, ou uma classe de animais, notadamente os animais de caça. Em guerra contra os humanos da mesma forma que os humanos estão em guerra contra eles (já que aqueles os caçam para se ali- 
mentar), os animais se vingam dos humanos enviando-Ihes doenças para "comêlos". Daí o dilema evocado pelo informante de Knud Rasmussen - um inuit, no caso, mas poderia certamente ter sido um indígena amazônico: "o maior perigo da vida é que o alimento humano constitui-se inteiramente de almas"15. Mesmo uma morte acidental pode se inscrever nessa lógica, com os índios postulando que, na origem da cadeia de causas imediatas que levaram à morte - queda de uma árvore, afogamento em uma cachoeira -, há uma fome que exige ser apaziguada. A morte e os estados patológicos que a prefiguram não são "fatos da natureza", acidentes biológicos necessários: trata-se antes de acidentes da vida relacional, ligados à coexistência de coletivos em luta contínua uns contra os outros para se alimentar e manter seu efetivo por meio da captura de indivíduos oriundos de outras populações ou espécies (fig. 35).

Os agentes nocivos responsáveis pelos estados de mal-estar, de sofrimento psíquico ou moral, e sobretudo por uma doença grave ou pela morte operam de duas maneiras principais: seja introduzindo no corpo da vítima "objetos animados" - frequentemente concebidos como minúsculas armas vivas, como dardos de zarabatana ou anzóis vivos, organizados em "bandos" ou mesmo espécies distintas, que devoram a vítima por dentro-, seja, ao contrário, apossando-se da "alma" da vítima, impedindo-a de voltar ao corpo, o que pode levar à consumição deste último. Os executores dessas ações são distinguidos do "mandante", que controla os seus pacotes de dardos e estabelece com eles relações de filiação parental ou quase parental. O modo de operação atribuído aos agentes patogênicos responsáveis pela doença justifica que os índios não atribuam quase nenhum peso à distinção entre uma morte feita com uma arma visível e um assassinato à distância

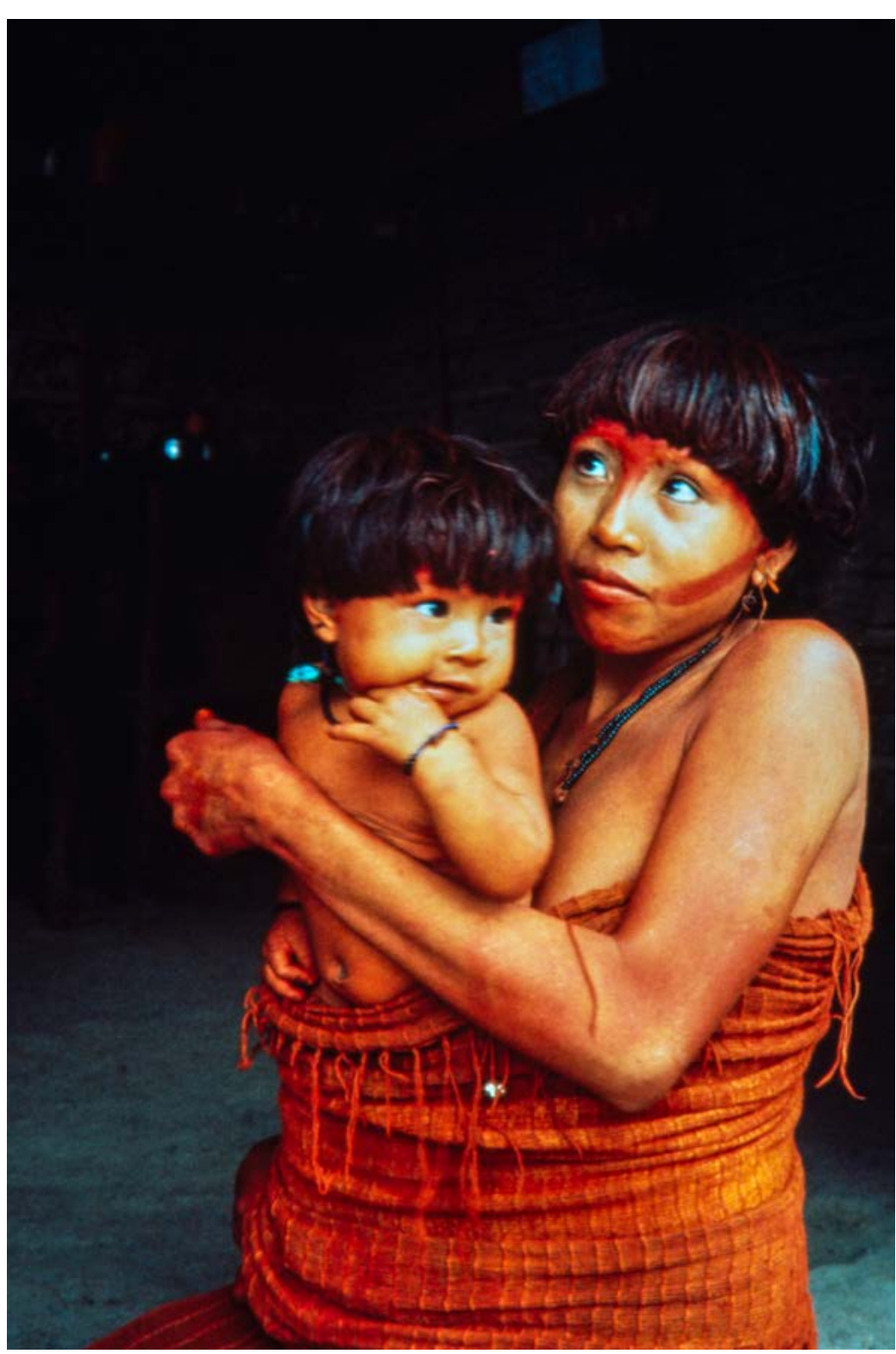

15 [Nota da Tradução] Tradução literal do original em inglês.

Figura 35 Jovem mulher carregando seu filho. População araweté (19811983). Foto de Eduardo Viveiros de Castro. "Os bebês não podem ser impedidos de interagir com os não humanos, que os vigiam e entretanto os fazem de presa". 
perpetrado por um inimigo por meio de sua parentela de "micróbios" hostis.

Entretanto, a predação exercida por não humanos sobre o coletivo dos humanos vivos não é necessária ou exclusivamente animada pela raiva ou pela "fome" própria ao guerreiro.

Da mesma forma que os índios amansam animais selvagens ou convertem espíritos em congêneres para incorporá-los ao próprio coletivo, os não humanos buscam às vezes amansar um humano - as crianças são particularmente visadas (fig. 36) - a fim de atraí-lo para sua sociedade, com consequências na maioria das vezes letais para a vítima, exceto no caso dos xamãs.

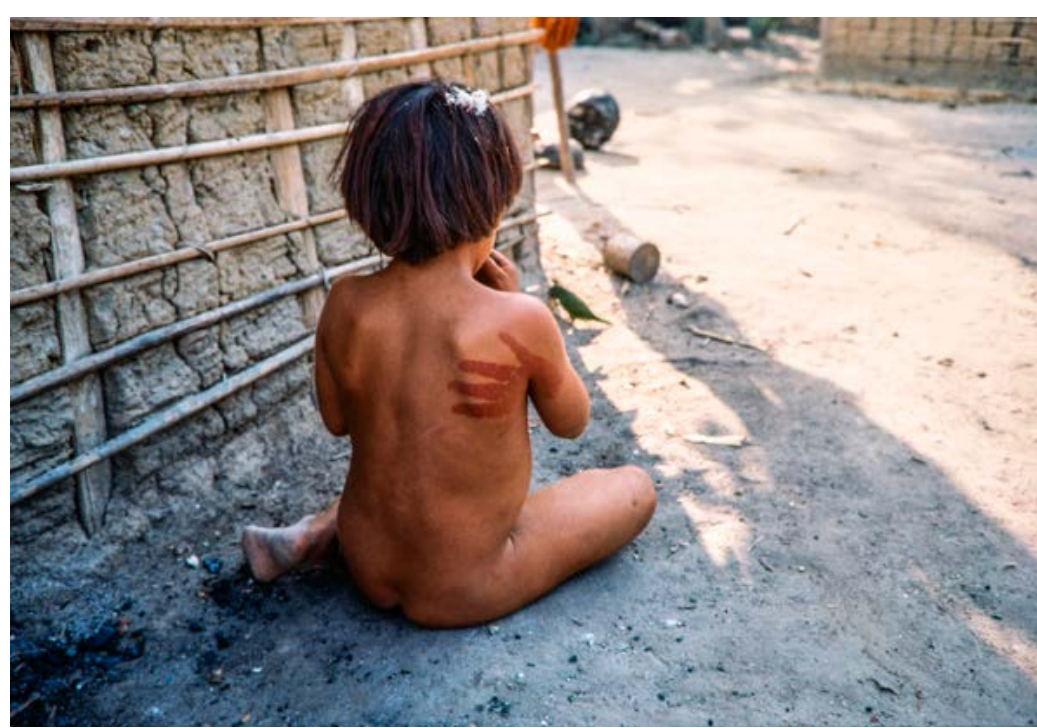

Figura 36

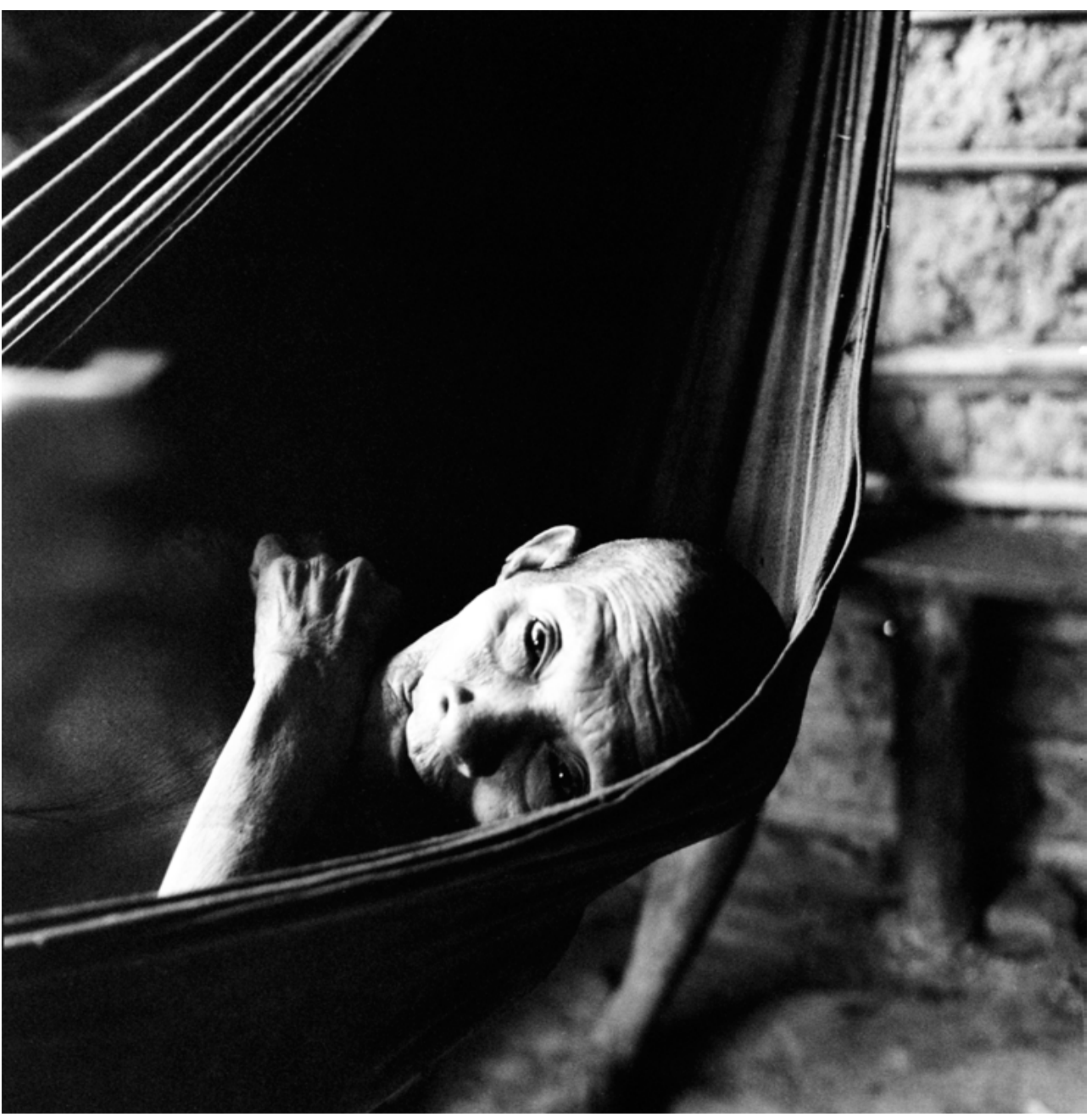

Figura 37

Velha indígena em uma rede (1981-1983). Foto de Eduardo Viveiros de Castro. "A morte e a doença trazem uma alienação corporal que nunca é acidental". 
Seja a predação contra os humanos violenta e agressiva, animada por uma fome assassina, ou ditada pela saudade, pela necessidade de companhia ou pela preocupação de enriquecer e aumentar seu próprio coletivo, o resultado é o mesmo: uma alienação que transforma os semelhantes em não humanos espíritos, deuses, animais de caça, inimigos, às vezes tudo isso ao mesmo tempo - e desencadeia a morte e a subtração de um membro do coletivo dos viventes (fig. 37). A doença e a morte resultam em uma transformação corporal sofrida, imposta por um outro hostil. É uma versão negativa da metamorfose-buscada e assumida pelo sujeito - na direção de estados de superpotência corporal.

\section{Aliado de seus predadores: o xamã}

Os estados patológicos provocados pelas pequenas armas animadas que devoram desde o interior e de maneira invisível a carne dos humanos, infligindo-lhes um afeto corporal involuntário e doloroso, exigem a intervenção terapêutica de um xamã, por pouco que se prolonguem ou se agravem.

A aptidão do xamã em curar as vítimas de uma predação invisível relacionase com a natureza particular de seu corpo - e do saber a ele associado. O xamã é um ser bifronte, capaz de aparecer como congênere a duas espécies ordinariamente estrangeiras uma para a outra e ligadas por uma relação de predação: por exemplo, a dos humanos e a dos animais de caça, ou, ainda, a dos humanos e a de uma dada categoria de espíritos canibais. O xamã adquiriu esse desdobramento corporal ao cultivar uma relação amistosa - uma relação de congênere ou de parente-com não humanos, frequentemente graças a um encontro fortuito. Tais encontros costumam tomar a forma de uma sedução do humano por um não humano do sexo oposto, culminando em uma relação estável de conjugalidade. A "dupla nacionalidade" ontológica do xamã pode igualmente resultar de uma adoção por um animal-espírito - frequentemente um jaguar encontrado em sonho ou na solidão da floresta, e que se tomou de compaixão pelo humano em sofrimento. Enquanto para a maioria dos humanos o comércio acidental com não humanos termina tragicamente no consumo de um pelo outro, o xamã consegue aparentar-se com os não humanos.

Essa aptidão Ihe confere a capacidade de ver a alma desses outros, isto é, de percebê-los tal como são vistos por seus próprios congêneres. Por possuírem esse tipo de saber, os xamãs têm frequentemente um estatuto social equivalente ao do sábio ou ao do intelectual, e exercem às vezes funções similares às de um sacerdote. Sua capacidade de serem vistos como congêneres tanto por seus aliados invisíveis quanto por seus próprios parentes humanos os predispõe a agir como diplomatas entre as duas populações, monitorando e intermediando suas relações. Assim, ao recuperar um doente que está 
em vias de passar a afiliar-se a um outro coletivo - ou seja, que está morrendo -, o xamã negocia uma troca com seus aliados não humanos: propõe que estes entreguem o doente aos humanos em troca de uma compensação, por exemplo, o corpo de um inimigo; ou, ain$d a$, que autorizem uma extração moderada dos animais de caça sob o cuidado desses aliados, em troca de alguns humanos que estes adoecerão para fazer deles sua própria caça (fig. 38). No mesmo sentido, para interromper a consumação de um doente pelos espíritos, visto por eles como presa, o xamã se esforça - cobrindo o corpo do doente com pinturas corporais, por exemplo - para fazê-lo aparecer como um congênere aos espíritos. O xamã busca persuadir os não humanos de que eles se enganam de alimento: o doente é um humano, como eles, e não uma presa à disposição de seu apetite.

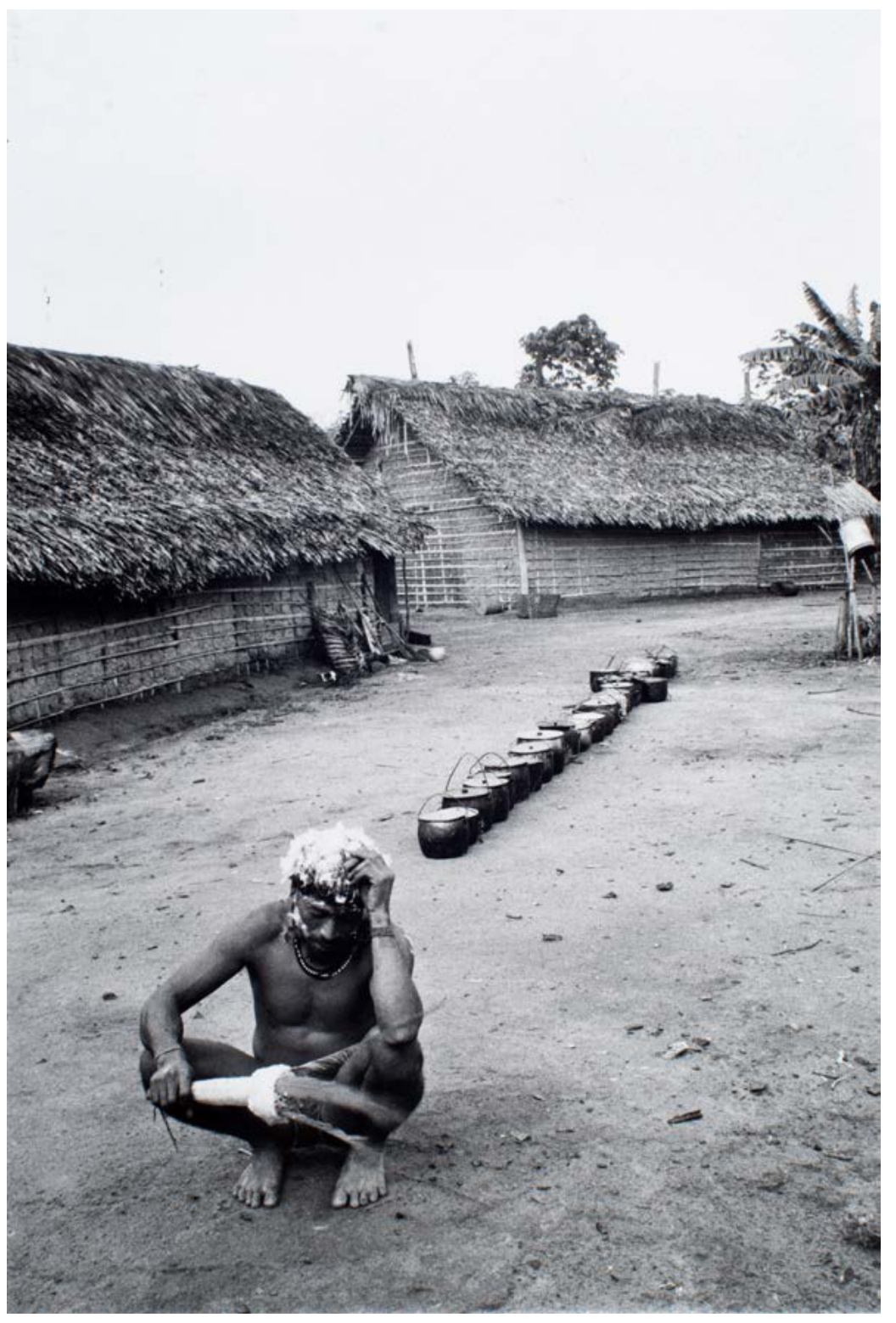

Figura 38

Xamã dando as costas em respeito à chegada dos espíritos descidos à terra para comer jabuti (1981-1983). Foto de Eduardo Viveiros de Castro. "O maior perigo da vida é que o alimento humano constituise inteiramente de almas", confidenciava um xamã inuit à Knud Rasmussen". vista. Uma mudança na percepção e na categorização de um alter supõe uma mudança paralela de regime corporal; portanto, mudar de corpo é mudar de ponto de vista. Vê-se então que os estados alterados de corporeidade podem ser tanto estratégias de conhecimento, se forem deliberadamente provocados, quanto sintomas patológicos, se forem involuntários. Por isso, os povos indígenas da Amazônia desenvolveram uma vasta gama de práticas visando a agir 
sobre a matéria corporal, modificar a consciência e a experiência do corpo, tanto para produzir modificações positivas como para evitar estados indesejáveis.

Antes de detalhar essa técnicas, algumas observações se impõem em relação à natureza geral da transformação por elas visada. Nosso imaginário cultural, ilustrado pelos escritos de Ovídio ou de Kafka, pensa a metamorfose como uma transformação involuntária do envelope corporal de um indivíduo, cujo núcleo central - a alma, a consciência - permanece, porém, humano. A força trágica dessas fábulas vem precisamente da descrição dos tormentos de uma consciência humana sentindo sua própria transfiguração em uma existência muda, ao se perder dentro de um corpo de um ser da natureza. A metamorfose, tal como a concebem os índios, se refere a um processo inverso: é a interioridade que se transforma primeiro e dita uma mudança corporal mais ou menos literalmente expressa. O "devir jaguar" do guerreiro amazônico não consiste em disfarçar-se de jaguar e dar curso a uma raiva completamente humana, imitando eventualmente comportamentos de carniceiro. Trata-se, antes, de sofrer uma modulação da subjetividade, uma intensificação qualitativa da disposição predadora, de tal modo que o sujeito acessa por um tempo a interioridade de um corpo de um jaguar. Essa metamorfose pode permanecer invisível para os congêneres do "jaguarizado", sem resultar em uma transformação paralela do corpo humano em corpo de felino e sem se manifestar senão por sinais indiretos (alteração da fala, do comportamento social) — em suma, por sintomas, como ocorre também no caso das doenças, essas metamorfoses involuntárias.

\section{Modificar a experiência corporal para trocar de corpo}

A mudança que focaliza a atenção dos índios concerne à subjetividade, não à forma aparente. Entretanto, como a consciência é a imagem do corpo, o meIhor meio de agir sobre ela é o de modificar o corpo que ela reflete. A forma mais elementar de efetuar essa modulação é a de variar o regime alimentar. Este categoriza os seres, define sua identidade ou sua diferença, abre a filiações inéditas ou, ao contrário, as previne. A atenção obsessiva que os indígenas atribuem àquilo que comem se explica por essas funções. Proibir-se tal tipo de alimento equivale a se desafiliar de um coletivo, definido por suas maneiras de comer, a fim de ingressar em um outro. Obrigar-se a consumir tal tipo de alimento, a provar tal tipo de sabor permite agregar à própria carne um agente de mudança, um elemento do regime próprio a uma dada espécie, humana ou não humana. Deve-se analisar a prática da êmese (vômito) voluntária, por vezes ritual e ocasional, por vezes cotidiana, na mesma perspectiva. O vômito visa ao mesmo tempo a tornar o corpo mais leve, mais aéreo - como o é o dos espíritos - e a limpar o organismo de restos acumulados durante os 
festins noturnos, talvez duvidosos, nos quais a "alma" teria eventualmente participado durante suas errâncias oníricas (fig. 39). Outra maneira de fazer variar o regime corporal consiste em mudar sutilmente a qualidade desses "amarras" imediatas do corpo ao seu entorno que são a respiração ou a percepção do ambiente sonoro e tátil. Uma das numerosas funções do tabaco, essa planta tão prezada pelos ameríndios, é a de produzir, por sua fumaça, um "ar sensível" diferente daquele no qual o corpo está envolvido. São utilizados também, para este mesmo fim, os maços de folhas com os quais os xamãs refrescam o corpo de seus pacientes, bem como os chocalhos, que servem para criar um meio sonoro e tátil "outro", próprio ao ambiente de uma espécie não humana (figs. 40 e 41).

A dor, mais ou menos viva, representa uma forma extrema de modificação da subjetividade pelo viés do corpo. O sofrimento físico constitui uma das mais imediatas e impressionantes vivências que permitem experimentar uma mudança interna do corpo. Por essa razão, numerosos rituais amazônicos, notadamente aqueles relacionados à iniciação, constituem-se de provas dolorosas, destinadas simultaneamente a fazer o neófito passar por uma perturbação de sua natureza corporal, tornar memorável essa experiência de mudança, e dar a

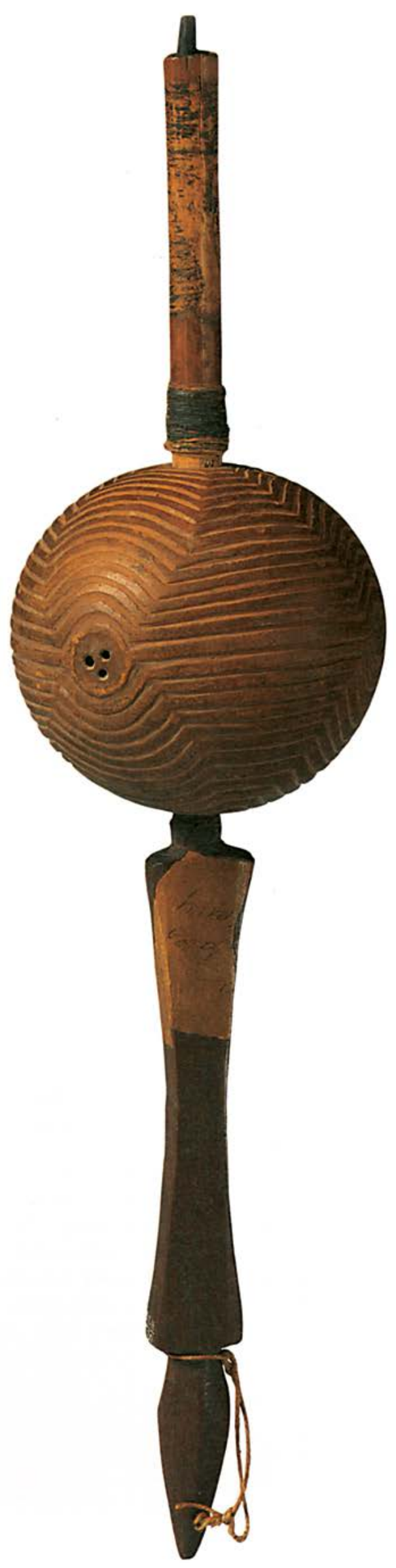

812

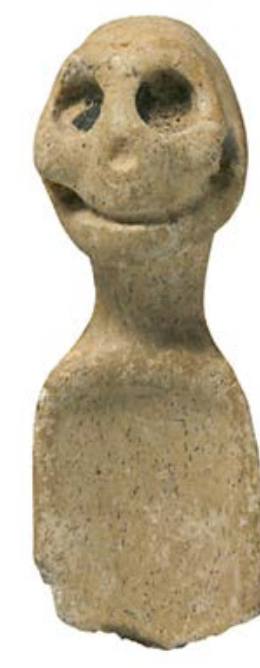

Figura 39

Espátula para vomitar, em madeira esculpida, população taino.

A $7 \mathrm{~cm}$. Inv. 71.1939.41.190 Acervo Musée du quai Branly (Paris).

"Vomita-se para deixar leve o corpo e torná-lo semelhante ao dos espíritos, para purgar os resíduos de sombrias festas oníricas, para passar de um regime alimentar a outro".
Figura 40

Chocalho de xamã.

L 29 cm. Inv. 71.1937.11.30. Acervo Musée du quai Branly (Paris). 


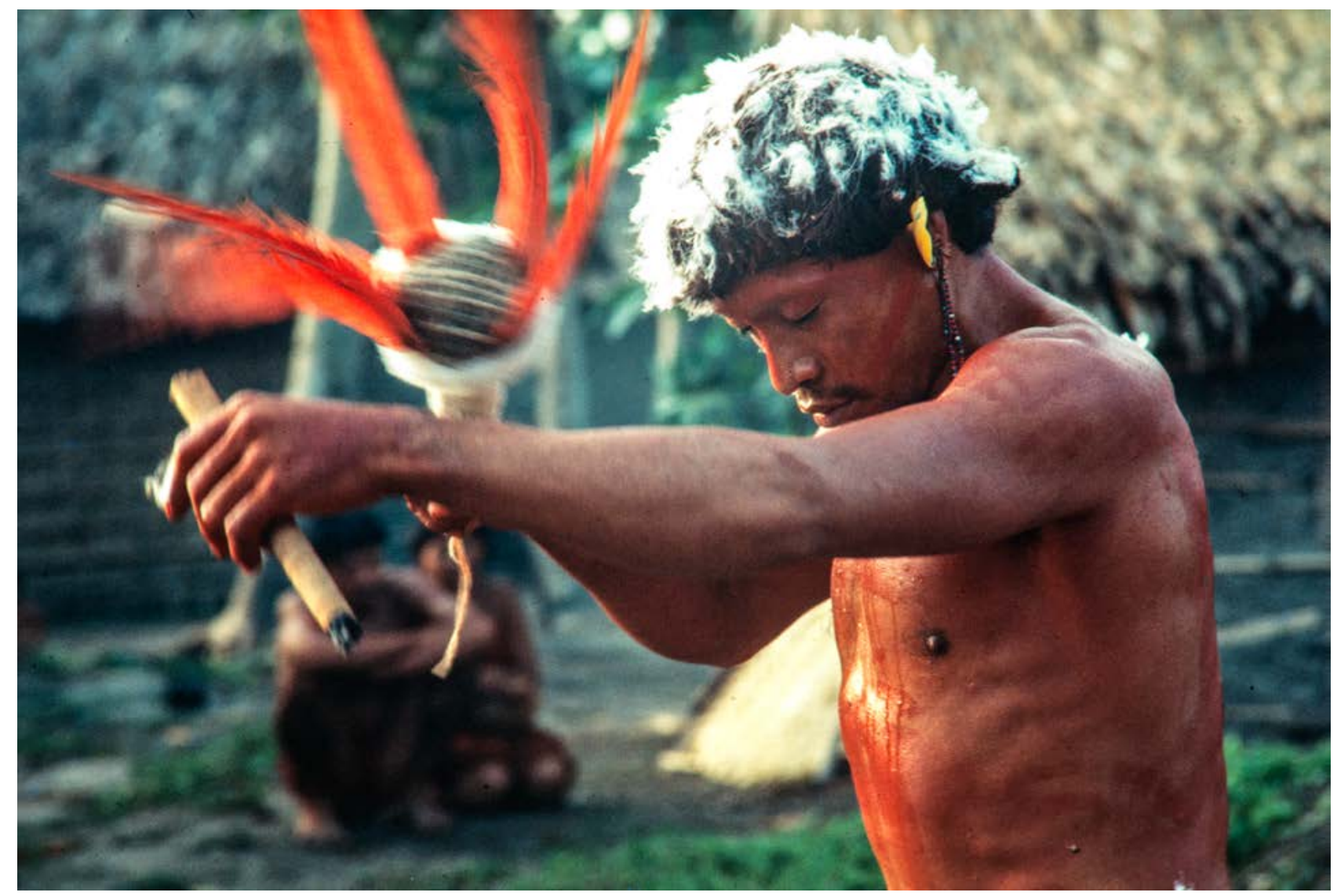

ele a oportunidade de exibir sua capacidade de controlar tal experiência -e portanto de se controlar a si mesmo. Os povos indígenas lançam mão de um importante arsenal de instrumentos de dor e de medo, desde os trançados e as luvas de cestaria nas quais eles fixam vespas ou tocandiras (figs. 42 e 43) até os escarificadores destinados a fazer verter sangue e marcar a pele. Notemos de passagem que, se os amazônicos se dedicam de bom grado a formas mais ou menos severas de automutilação, eles não se envolvem senão excepcionalmente em atos de tortura praticados sobre outrem. Infligir dor para destruir, humilhar ou "desumanizar" não tem nenhum sentido para eles. Exercício de conhecimento antes que de punição, o sofrimento assume um valor positivo, e não é portanto imposto senão aos semelhantes.

A introdução no organismo de substâncias que provocam sensações mais ou menos fortes de mal-estar permite modular a pro-

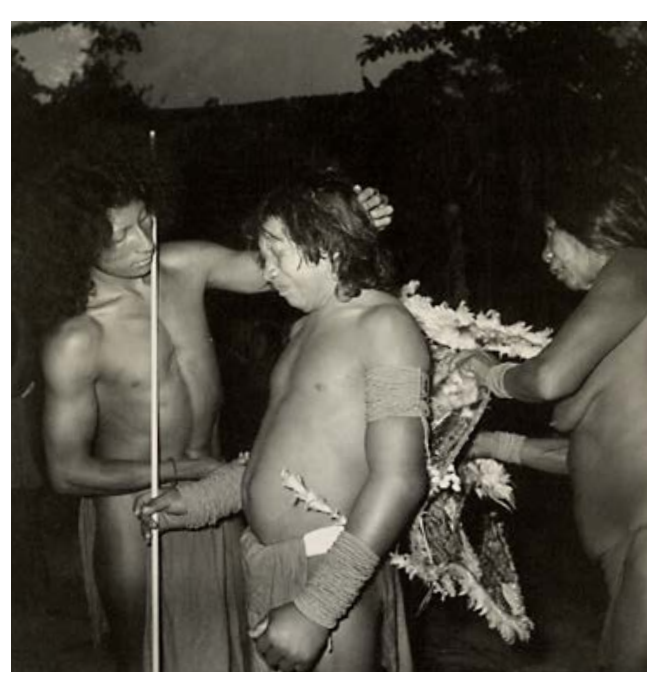

\section{Figura 42}

Indígena da Guiana sofrendo a aplicação da peneira com formigas (1965). Foto de Jean-Marcel Hurault. "A experimentação de dor permite uma transformação corporal". 


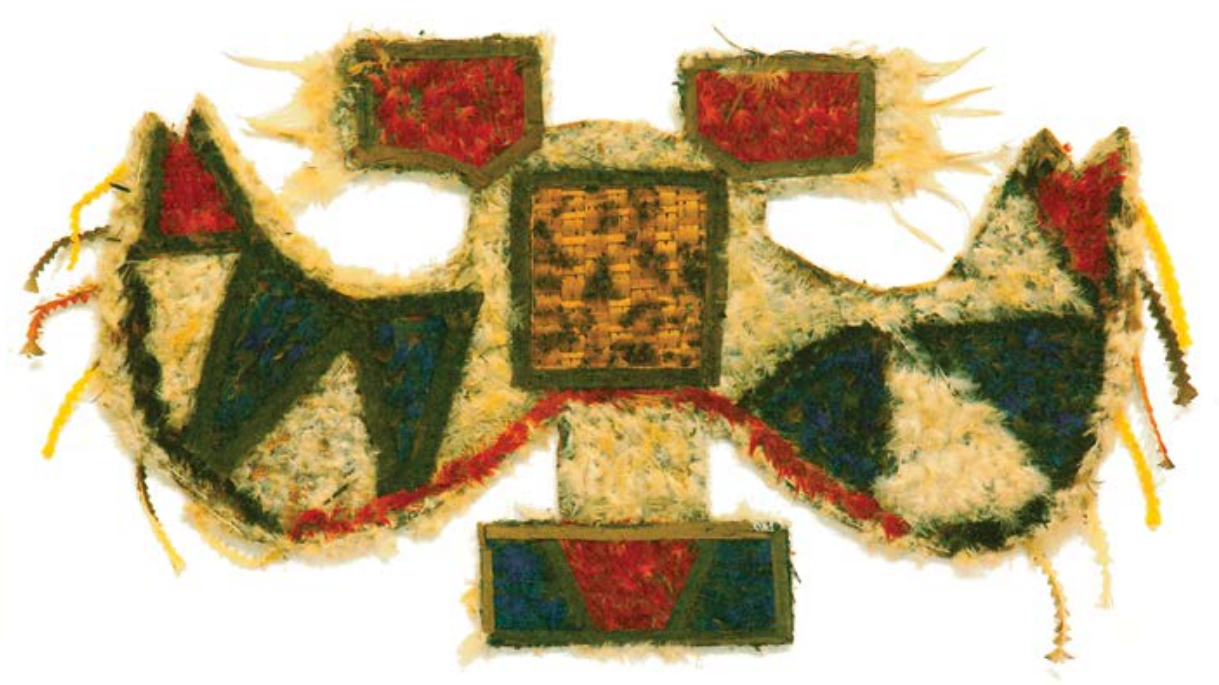

Figura 43

Aplicador de formigas.

L $94 \mathrm{~cm}$. Inv. 70.2003.2.2.

Acervo Musée du

quai Branly (Paris).

Figura 44 Xamã com um aplicador de rapé alucinógeno população bará, grupo tukano (início dos anos 1980). Foto de Cerardo Reichel-Dolmatoff "Alteram-se os estados de consciência para conhecer uma corporeidade diferente".

priocepção, e a percepção sensorial em geral, de uma maneira menos espetacular - mas, às vezes, mais perigosa. Os rapazes cashinahua, por exemplo, de vez em quando injetam em si mesmos doses infinitesimais de veneno de dendrobata (essa pequena rã tropical que secreta uma substância altamente tóxica) para endurecer seus corpos, habituando-os a absorver o "amargor", o que os deixa violenta e, às vezes, mortalmente doentes. Da mesma forma, os efeitos eméticos e angustiantes de numerosos psicotrópicos amazônicos, longe de serem "efeitos colaterais" indesejáveis, como se pensou por muito tempo, são deliberadamente procurados, pois eles assinalam e simbolizam uma metamorfose corporal paralela à alteração da consciência. Uma versão "light" desse trabalho sobre o corpo consiste em orná-lo de "enfeites medicinais": assim, os Cashinahua adornam

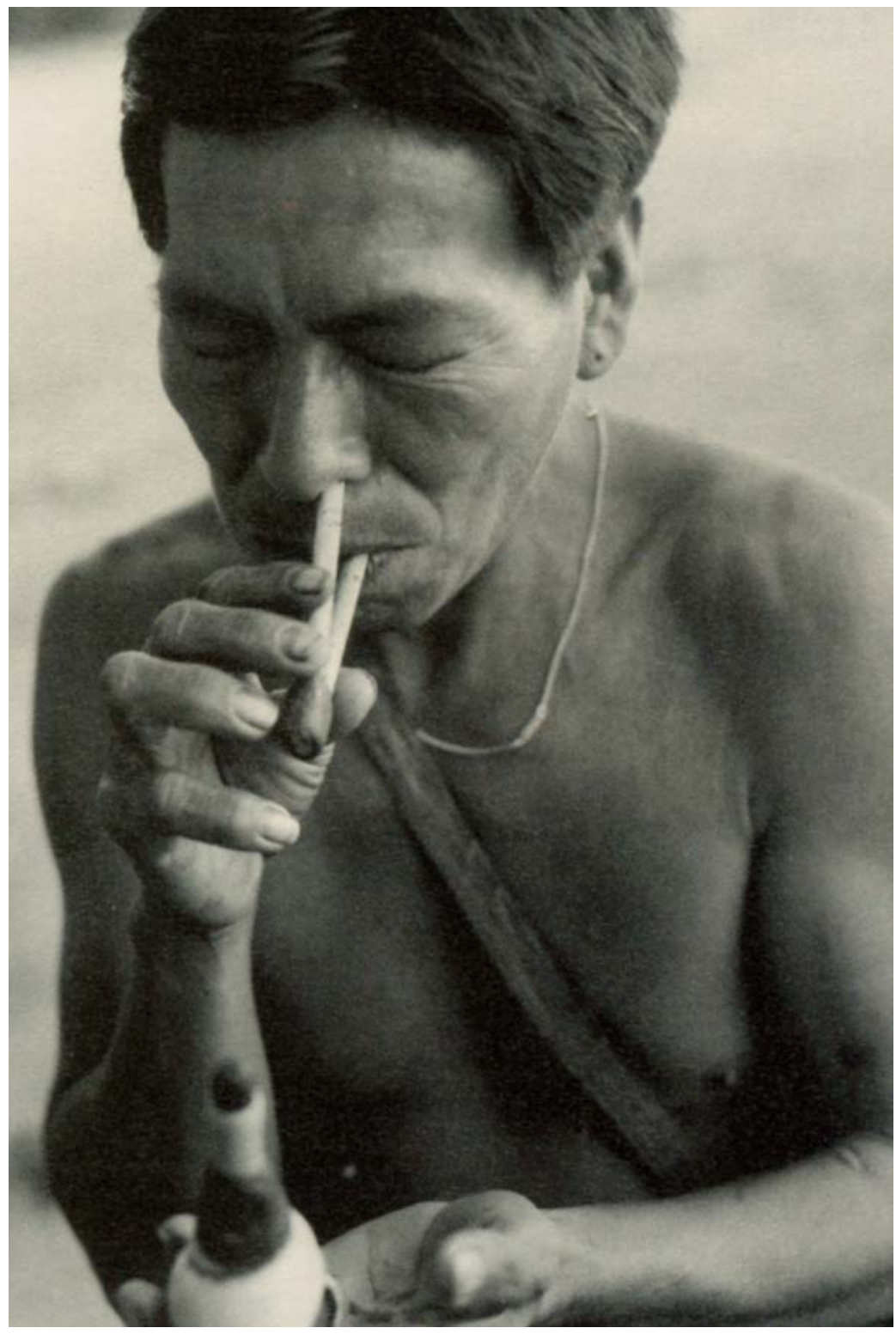


braçadeiras e jarreteiras com maços de plantas medicinais, cujo perfume se insinua na carne e a transforma para torná-la mais apta a interagir com tal ou qual espécie não humana. Todos os enfeites têm uma função "performativa": ao portá-los, absorvemos uma parte da intencionalidade investida no corpo animal ou vegetal do qual eles provêm (fig. 45). O fato de que em certas línguas da família Pano o mesmo vocábulo designa "plumas" e "remédio" não é mero acidente. A pintura facial, técnica de modulação da matéria corporal, é combinada com "remédios" para dotá-la de um odor, de uma potência de atração ou de repulsão. Na medida em que ela é uma "pele de espécie", é lógico que ela deva liberar um perfume, já que todas as espécies se caracterizam por um odor particular.

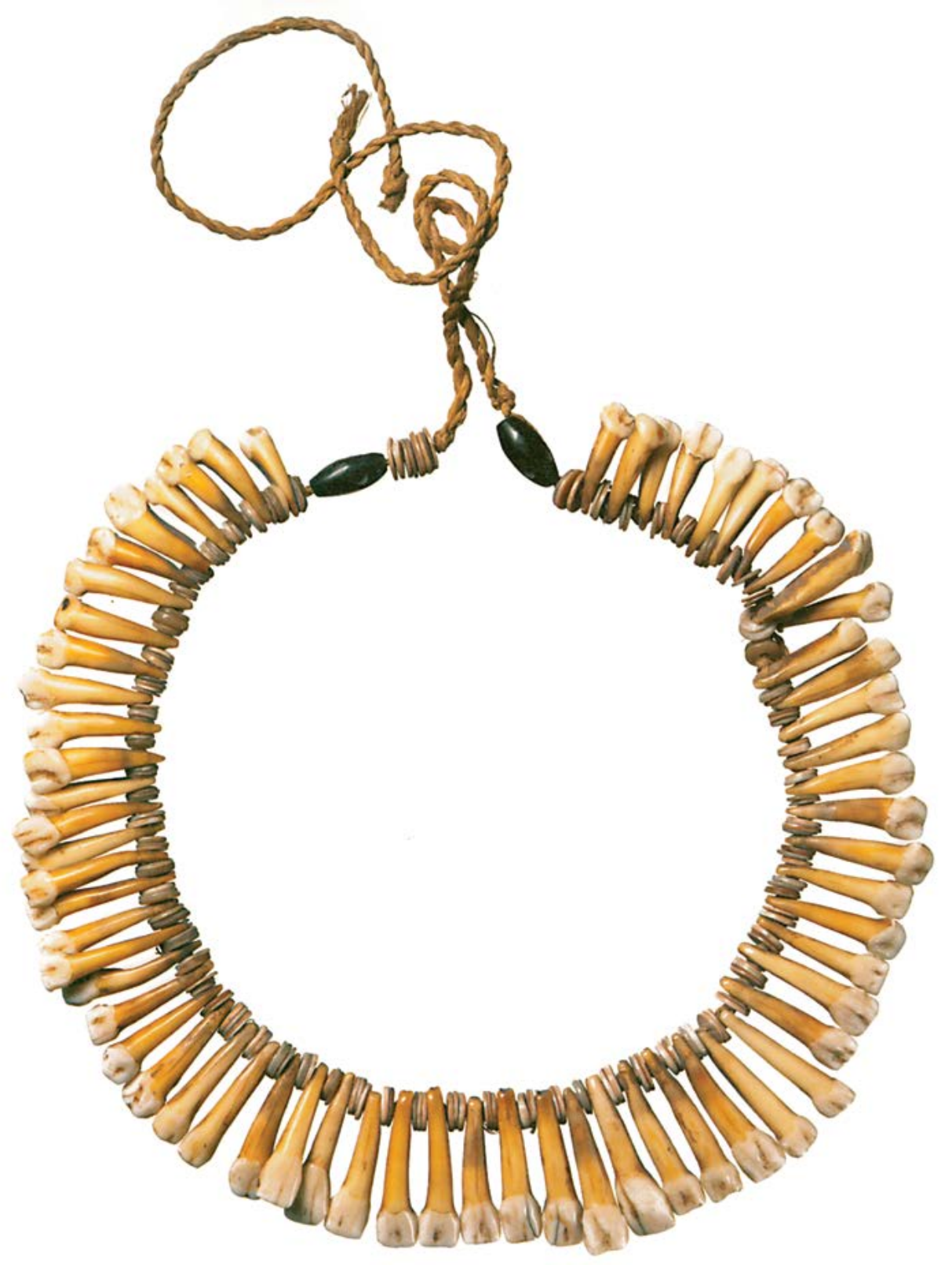

Figura 45

Colar de dentes humanos. Peru. A $27 \mathrm{~cm}$. Inv. 71.1938.147.21. Acervo Musée du quai Branly (Paris). 


\section{Mudar de consciência para se dar um outro corpo}

A ingestão - por decocção, inalação, mastigação - de substâncias que alteram mais ou menos fortemente o estado normal da consciência constitui uma outra técnica de modificação da subjetividade. Os índios utilizam um vasto inventário de substâncias psicotrópicas, cuja riqueza a farmacologia ocidental apenas começa a avaliar. Além do tabaco e da coca, cujos efeitos de alteração de consciência não são sempre perceptíveis para um consumidor inexperiente, as drogas mais correntemente utilizadas são o yajé, também conhecido como ayahuasca ou caapi (Banisteriopsis caapi), e as trombetas (Brugmansia sp.), ambas consumidas na forma de uma bebida obtida por redução da decocção das cascas, e também o rapé (inalado por meio de canudos) de Virola elongata ou de Anadenanthera peregrina (fig. 44). Existem muitas outras substâncias, a maioria composta de muitas plantas, em função das sensações procuradas ${ }^{16}$. O desenvolvimento de uma cultura da droga entre os índios da Amazônia, que se mostra muito antiga, já que os instrumentos que lhe são associados (cachimbos, pranchetas e inaladores) foram encontrados por arqueólogos em sítios de alta antiguidade, se ajusta perfeitamente às noções indígenas sobre as relações entre o corpo e a consciência e a representação desse corpo. O objetivo visado pela ingestão de psicotrópicos é o mesmo que aquele perseguido nas operações sobre a carne: ter acesso à experiência da metamorfose. Entretanto, a droga inverte a direção do processo evocado nos parágrafos precedentes: em lugar de trabalhar o corpo para modificar a consciência, levando-a a experimentar sensações corporais incomuns, a droga altera a consciência ou a percepção corporal e permite fazer a experiência de um corpo "outro" sem intervir diretamente no próprio corpo, e sem que essa transformação seja visível nele. Um dos exemplos mais impressionantes de uma metamorfose corporal vivida pela consciência, invisível aos espectadores, é aquele que experimentam os xamãs yanomami sob o efeito do pó yakoana (resina de casca de Virola elongata). No decorrer de seu transe, eles se tornam espíritos, mas seus corpos não refletem essa transformação senão por seu comportamento aberrante, sugestivo de uma "biologia" e de uma "física" diferentes daquelas que prevalecem no mundo dos humanos.

Como a dor e outras experiências de perturbação corporal, a alteração deliberada da consciência obedece a uma vontade de conhecimento e, por conseguinte, de sociabilidade alargada: drogar-se de maneira controlada permite ver a "outra face" de seres que em momentos normais não aparecem, ou só aparecem sob uma forma não humana; permite apresentar-se a eles com um corpo de congênere e desenvolver com eles relações "humanas", isto é, relações de parentesco ou quase parentesco.
16 A bebida enteógena conhecida como yajé ou santo daime (ayahuasca, caapi, mariri etc.) é uma mistura onde entram a casca do cipó Banisteriopsis e folhas do arbusto Psychotria viridis. [Nota de Viveiros de Castro acrescentada à esta tradução.] 


\section{Cinco séculos atrás, a mesma história}

Claude Lévi-Strauss se refere várias vezes em sua obra a uma anedota retirada de História das Índias, de Gonzalo Fernández de Oviedo: "Nas Grandes Antilhas, alguns anos após a descoberta da América, enquanto os espanhóis enviavam comissões de inquérito para investigar se os indígenas tinham ou não uma alma, estes se dedicavam a afogar os brancos que aprisionavam, a fim de verificar, por uma demorada observação, se seus cadáveres eram ou não sujeitos à putrefação". A história vem assim ilustrar a tese de uma natureza humana caracterizada pela negação obstinada de sua própria universalidade: de fato, a humanidade do outro é colocada em questão tanto pelos índios quanto pelos europeus. O etnocentrismo seria, portanto, a coisa mais bem partilhada no mundo, mesmo se, "igualmente ignorante", como diz Lévi-Strauss, a atitude dos índios era mais respeitável: eles projetavam uma divindade nos brancos enquanto estes tomavam os índios por animais. O episódio revela sobretudo a distância decisiva entre os europeus e os ameríndios em sua maneira de considerar a alteridade. Se os índios, como nota com ironia Lévi-Strauss, recorreram às ciências naturais para determinar o estatuto ontológico dos brancos, enquanto estes se apoiaram nas ciências humanas para decidir sobre a bestialidade dos índios, é porque, para os ameríndios, a diversidade dos seres se situa no nível do corpo e, para os europeus, no plano da alma. Os ocidentais nunca tiveram dúvidas de que os índios tinham um corpo (os animais também o têm). Os índios, por seu turno, nunca duvidaram de que os brancos tinham uma alma (os animais e os espíritos a têm também). Assim, o etnocentrismo dos ocidentais consistia em duvidar que os corpos outros tivessem uma alma como a sua; o dos índios consistia em duvidar de que almas outras pudessem ter um corpo idêntico ao seu.

Desse primeiro quiasma decorre toda uma série de diferenças, frequentemente mascaradas por convergências de fachada. A noção de sujeito, tal como ela é concebida no ocidente e nas ontologias indígenas, sintetiza as diferenças principais. Para nós, a intimidade do sujeito, seu núcleo mais central, se situa acima da cultura, e isso torna o sujeito universal. A forma de interioridade que ele sintetiza é, entretanto, reservada apenas aos humanos. Para os indígenas da América, o sujeito é por princípio "cultural", mas essa inscrição na ordem da cultura, longe de limitar a qualidade de pessoa apenas aos membros desta ou daquela "tribo", está no fundamento de uma distribuição de subjetividade que transborda largamente a espécie humana. As entidades-sujeito têm necessariamente todos os atributos da cultura, incluindo aí os corpos, que não diferem daquele dos humanos por sua organização e sua forma geral. Assim, todos os sujeitos se parecem: do ponto de vista de sua qualidade de sujeito e, portanto, 
de sua subjetividade, eles são idênticos, sejam animais, plantas ou espíritos.

Eles se diferenciam por sua "fisicalidade", pelo mundo de relações que lhes oferecem os recursos de seu corpo de espécie. A metafísica dos índios da Amazônia apresenta, portanto, uma configuração inversa àquela que subjaz às nossas próprias concepções do mundo: a identidade entre humanos e não humanos não remete à natureza, como é o caso entre nós (que aceitamos ter em comum com os animais uma parte "natural" de bestialidade), ela repousa sobre o compartilhamento da mesma cultura. É exatamente por isso que o corpo indígena é diferente do nosso. 